Prepared in cooperation with the City of Creede, Colorado and the U.S. Forest Service

\title{
Evaluation of Metal Loading to Streams near Creede, Colorado, August and September 2000
}

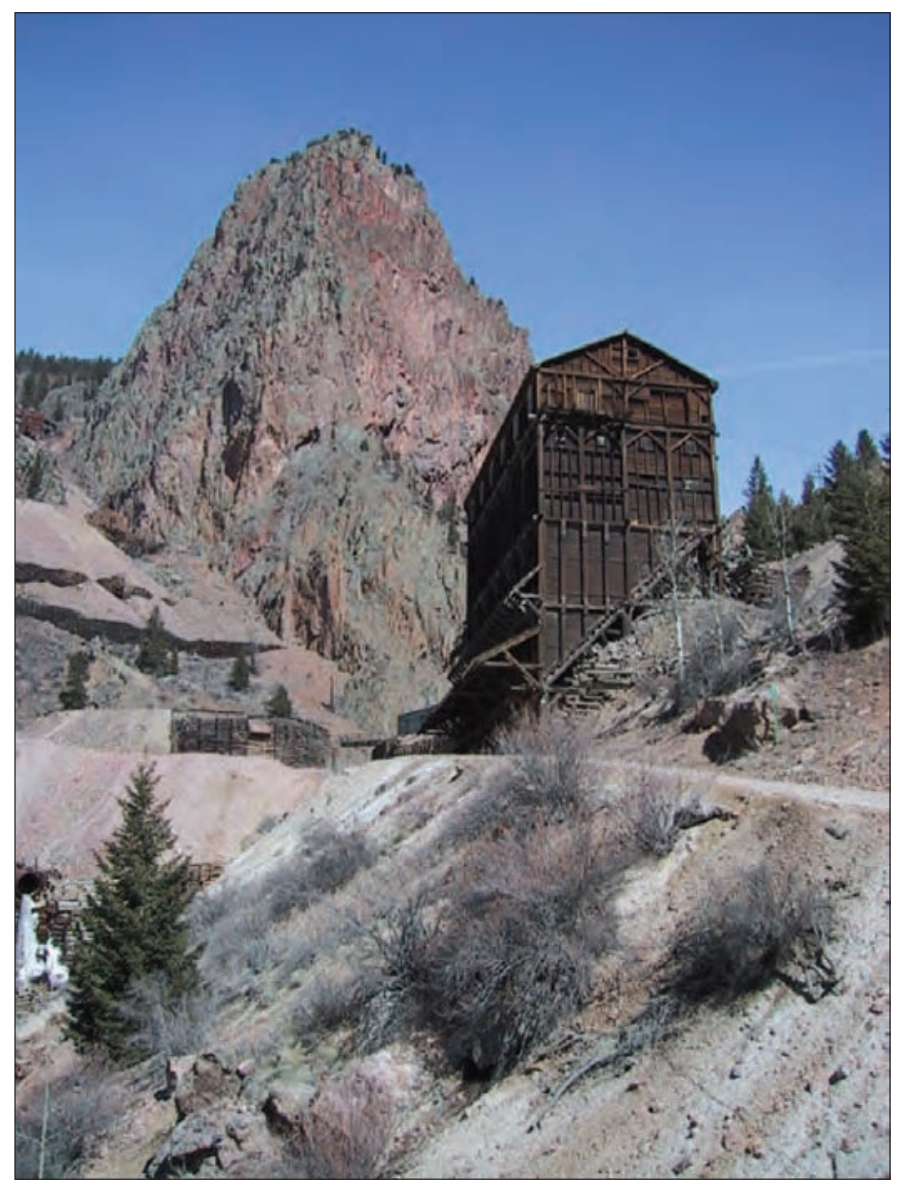

Scientific Investigations Report 2004-5143 



\section{Evaluation of Metal Loading to Streams near Creede, Colorado, August and September 2000}

By B.A. Kimball, R.L. Runkel, K. Walton-Day, and B.K. Stover

U.S. Geological Survey

SCIENTIFIC INVESTIGATIONS REPORT 2004-5143

Prepared in cooperation with the CITY OF CREEDE, COLORADO, and the U.S. FOREST SERVICE

Salt Lake City, Utah 


\section{U.S. DEPARTMENT OF THE INTERIOR}

GALE A. NORTON, Secretary

U.S. GEOLOGICAL SURVEY

P. Patrick Leahy, Acting Director

Any use of trade, product, or firm names in this publication is for descriptive purposes only and does not imply endorsement by the U.S. Government.

For additional information write to:

Copies of this report can be purchased from:

Director, Utah Water Science Center

U.S. Geological Survey

U.S. Geological Survey

2329 West Orton Circle

Salt Lake City, UT 84119

http://ut.water.usgs.gov

Branch of Information Services

Box 25286, Federal Center

Denver, CO 80225-0286

1-888-ASK-USGS 


\section{CONTENTS}

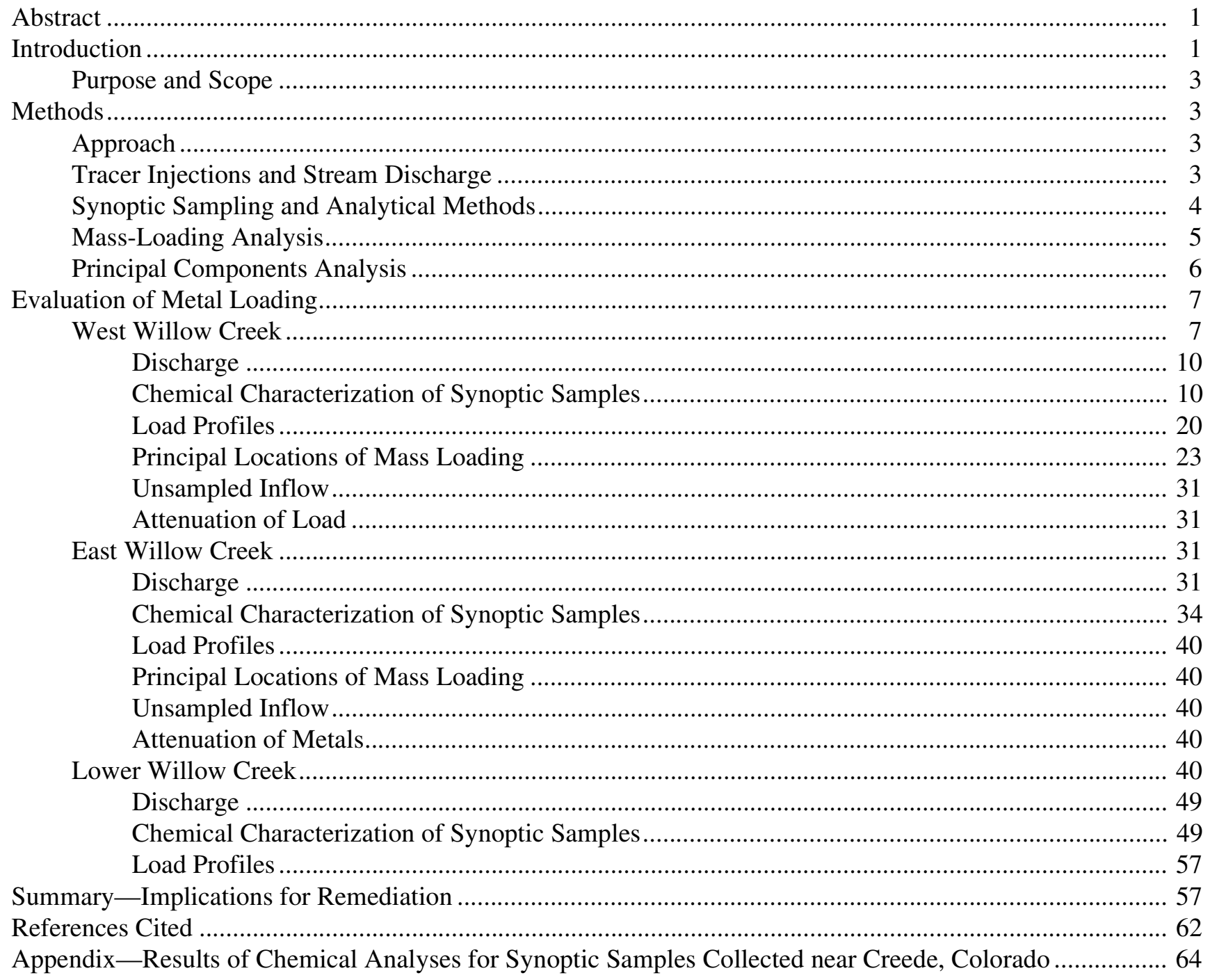




\section{FIGURES}

Figure 1. Map showing location of the Willow Creek watershed, indicating study reaches for tracerinjection study reaches and principal mines along the study reach near Creede, Colorado

Figure 2. Map showing location of stream segments and inflow samples for East and West Willow Creeks, Colorado

Figure 3. Graph showing variaton of bromide concentration and calculated discharge with distance along the study reach, West Willow Creek, Colorado, September 2000..

Figure 4. Graph showing variation of (a) $\mathrm{pH}$ and (b) calcium, sulfate, and alkalinity concentration with distance along the study reach, West Willow Creek, Colorado, September 2000.

Figure 5. Box plot showing distribution of dissolved (blue) and collodial (orange) metal concentrations in synoptic stream samples, West Willow Creek, Colorado, September 2000.

Figure 6. Graph showing variation of aluminum concentration in ultrafiltrate, $0.45-\mu \mathrm{m}$ filtered, and total-recoverable samples with distance along the study reach, West Willow Creek, Colorado, September 2000

Figure 7. Graph showing variation of iron concentration in ultrafiltrate, $0.45-\mu \mathrm{m}$ filtered, and totalrecoverable samples with distance along the study reach, West Willow Creek, Colorado, September 2000

Figure 8. Graph showing variation of zinc concentration in ultrafiltrate, $0.45-\mu \mathrm{m}$ filtered, and totalrecoverable samples with distance along the study reach, West Willow Creek, Colorado, September 2000

Figure 9. Graphs showing biplot of principal component scores for synoptic samples and loadings for chemical constituents, West Willow Creek, Colorado, September 2000

Figure 10. Graphs showing (A) variation of aluminum load with distance and (B) changes in aluminum load for individual stream segments, West Willow Creek, Colorado, September 2000 .....

Figure 11. Graphs showing (A) variation of manganese load with distance and (B) changes in manganese load for individual stream segments, West Willow Creek, Colorado, September 2000

Figure 12. Graphs showing (A) variation of zinc load with distance and (B) changes in zinc load for individual stream segments, West Willow Creek, Colorado, September 2000

Figure 13. Graphs showing (A) variation of strontium load with distance and (B) changes in strontium load for individual stream segments, West Willow Creek, Colorado, September 2000

Figure 14. Graphs showing (A) variation of sulfate load with distance and (B) changes in sulfate load for individual stream segments, West Willow Creek, Colorado, September 2000

Figure 15. Graphs showing (A) variation of iron load with distance and (B) changes in iron load for individual stream segments, West Willow Creek, Colorado, September 2000 28

Figure 16. Graphs showing (A) variation of cadmium load with distance and (B) changes in cadmium load for individual stream segments, West Willow Creek, Colorado, September 2000

Figure 17. Graphs showing (A) variation of lead load with distance and (B) changes in lead load for individual stream segments, West Willow Creek, Colorado, September 2000

Figure 18. Graph showing variation of bromide concentration and calculated discharge, East Willow Creek, Colorado, August 2000

Figure 19. Graphs showing variation of (A) $\mathrm{pH}$ and (B) calcium, sulfate, and alkalinity concentration with distance along the study reach, East Willow Creek, Colorado, August 2000

Figure 20. Box plot showing distribution of dissolved (blue) and collodial (orange) metal concentration in synoptic stream samples, East Willow Creek, Colorado, August 2000 
Figure 21. Graph showing variation of zinc concentration with distance along the study reach, East Willow Creek, Colorado, August 2000

Figure 22. Graph showing variation of iron concentration with distance along the study reach, East

Willow Creek, Colorado, August 2000

Figure 23. Biplot indicating classification of synoptic samples from East Willow Creek, Colorado, August 2000

Figure 24. Graphs showing (A) variation of sulfate load with distance and (B) changes in sulfate load for individual stream segments, East Willow Creek, Colorado, August 2000 .

Figure 25. Graphs showing (A) variation of strontium load with distance and (B) changes in strontium load for individual stream segments, East Willow Creek, Colorado, August 2000

Figure 26. Graphs showing (A) variation of manganese load with distance and (B) changes in manganese load for individual stream segments, East Willow Creek, Colorado, August 2000

Figure 27. Graphs showing (A) variation of zinc load with distance and (B) changes in zinc load for individual stream segments, East Willow Creek, Colorado, August 2000.

Figure 28. Graphs showing (A) variation of aluminum load with distance and (B) changes in aluminum load for individual stream segments, East Willow Creek, Colorado, August 2000

Figure 29. Graphs showing (A) variation of iron load with distance and (B) changes in iron load for individual stream segments, East Willow Creek, Colorado, August 2000

Figure 30. Map showing location of synoptic sampling sites, lower Willow Creek, near Creede, Colorado, August 2000 .

Figure 31. Graph showing discharge at sampling sites along the study reach, lower Willow Creek, Colorado, August 2000 .

Figure 32. Graph showing variation of $\mathrm{pH}$ with distance along the study reach, indicating paths of braids, lower Willow Creek, Colorado, August 2000

Figure 33. Box plot showing distribution of selected dissolved (blue) and colloidal (orange) metal concentrations, lower Willow Creek, Colorado, August 2000.

Figure 34. Graph showing variation of sulfate concentration with distance along the study reach, indicating paths of braids, lower Willow Creek, Colorado, August $2000 .$.

Figure 35. Graph showing variation of manganese concentration with distance along the study reach, indicating paths of braids, lower Willow Creek, Colorado, August 2000 ...

Figure 36. Graph showing variation of zinc concentration with distance along the study reach, indicating paths of braids, lower Willow Creek, Colorado, August 2000.

Figure 37. Graph showing total strontium load at synoptic sampling sites, lower Willow Creek, Colorado, August 2000.

Figure 38. Graph showing total sulfate load at synoptic sampling sites, lower Willow Creek, Colorado, August 2000.

Figure 39. Graph showing total manganese load at synoptic sampling sites, lower Willow Creek, Colorado, August 2000

Figure 40. Graph showing total zinc load at synoptic sampling sites, lower Willow Creek, Colorado, August 2000 


\section{TABLES}

Table 1. Sample identification, source, distance along the injection study reach, site description, $\mathrm{pH}$, specific conductance, tracer concentration, and calculated discharge for synoptic samples from West Willow Creek, Colorado, September 2000

Table 2. Median composition of stream and inflow groups distinguished by principal components analysis, West Willow Creek, Colorado, September 2000

Table 3. Summary of load calculations, West Willow Creek, Colorado, September 2000....................... 21

Table 4. $\quad$ Synoptic sampling sites, East Willow Creek, Colorado, August 2000..................................... 32

Table 5. $\quad$ Summary of load calculations, East Willow Creek, Colorado, August 2000............................. 41

Table 6. Synoptic sampling sites, lower Willow Creek, Colorado, August 2000 ................................. 50

Table 7. Change in load through study reach of lower Willow Creek, Colorado, August 2000 ............... 57

Table A-1. Physical properties of synoptic samples collected near Creede, Colorado, August and

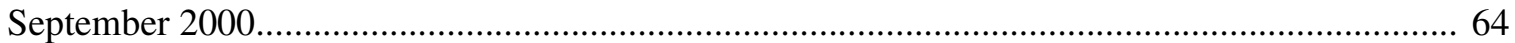

Table A-2. Concentration of chemical constituents in synoptic samples collected near Creede,

Colorado, August and September 2000 


\section{CONVERSION FACTORS, DATUMS, AND ABBREVIATED WATER-OUALITY UNITS}

\begin{tabular}{rcl}
\hline Multiply & By & To obtain \\
\hline kilogram per day $(\mathrm{kg} /$ day) & 2.2 & pound per day $(\mathrm{lb} /$ day $)$ \\
milligram per second $(\mathrm{mg} / \mathrm{s})$ & .1901 & pound per day $(\mathrm{lb} /$ day $)$ \\
liter per second $(\mathrm{L} / \mathrm{s})$ & .0353 & cubic foot per second $\left(\mathrm{ft}^{3} / \mathrm{s}\right)$ \\
meter $(\mathrm{m})$ & 3.281 & foot $(\mathrm{ft})$ \\
micrometer $(\mu \mathrm{m})$ & .000003281 & foot $(\mathrm{ft})$ \\
milliliter $(\mathrm{mL})$ & .000264 & gallon $(\mathrm{gal})$ \\
square kilometer $\left(\mathrm{km}^{2}\right)$ & .03861 & square miles $\left(\mathrm{mi}^{2}\right)$ \\
\hline
\end{tabular}

Water temperature in degrees Celsius $\left({ }^{\circ} \mathrm{C}\right)$ can be converted to degrees Fahrenheit $\left({ }^{\circ} \mathrm{F}\right)$ by using the following equation:

$$
{ }^{\circ} \mathrm{F}=9 / 5\left({ }^{\circ} \mathrm{C}\right)+32 .
$$

Horizontal coordinate information is referenced to the North American Datum of 1927 (NAD 27).

Chemical concentration and water temperature are reported only in metric units. Chemical concentration is reported in milligrams per liter $(\mathrm{mg} / \mathrm{L})$, micrograms per liter $(\mu \mathrm{g} / \mathrm{L})$, or millimoles per liter $(\mathrm{mM} / \mathrm{L})$. Milligrams per liter is a unit expressing the mass of solute per unit volume (liter) of water. For concentrations less than 7,000 milligrams per liter, the numerical value is about the same as for concentrations in parts per million. Specific conductance is reported in microsiemens per centimeter at 25 degrees Celsius $(\mu \mathrm{S} / \mathrm{cm})$. 
viii Conversion Factors, and Abbreviated Water-Quality Units 


\title{
Evaluation of Metal Loading to Streams near Creede, Colorado, August and September 2000
}

\author{
By B.A. Kimball, R.L. Runkel, K. Walton-Day, and B.K. Stover
}

\section{ABSTRACT}

Decisions about remediation of mine drainage on the watershed scale require an understanding of metal contributions from all sources to be able to choose the best sites for remediation. A hydrologic framework to study metal loading in the Willow Creek watershed, a tributary to the Rio Grande River near Creede, Colorado, was established by conducting a series of tracer-injection studies. Each study used the tracerdilution method in conjunction with synoptic sampling to determine the spatial distribution of discharge and concentration. Discharge and concentration data were then used to develop mass-loading curves for the metals of interest. The discharge and load profiles (1) identify the principal sources of load to the streams; (2) demonstrate the scale of unsampled, dispersed subsurface inflows; and (3) estimate the amount of natural attenuation. The greatest source of metal loads was from the Nelson Tunnel on West Willow Creek, which contributed 158 kilograms per day of zinc to the stream. Additional loading from other dispersed, subsurface inflows along West Willow Creek added substantial loads, but these were small in comparison to the loads from the Nelson Tunnel. No significant contributions of metal load from potential sources occurred along East Willow Creek. The lack of measurable loading may be a result of previous remedial actions along that stream. The lower Willow Creek section had relatively small contributions of load compared to what had been contributed upstream. This watershed approach provides a detailed snapshot of metal load for the watershed to support remediation decisions and quantifies processes that affect metal transport.

\section{INTRODUCTION}

Historical mining near Creede, Colorado, has produced silver, lead, zinc, and gold. Production of metals has been from veins along faults that formed during subsidence of the Creede caldera (Steven and Ratté, 1965). The mining activity in the Willow Creek watershed has affected conditions in the streams. A technical advisory group (TAC) has been working to make decisions about what might be done to improve stream conditions and to lessen the effect of metals in Willow Creek and downstream in the Rio Grande River. To support the decision-making process of the stakeholder group, the U.S. Geological Survey conducted three tracer-injection studies in the Willow Creek watershed in August and September 2000 to assess metal loading.

The Willow Creek watershed covers an area of about $26 \mathrm{~km}^{2}$. To study metal loading from the headwaters of Willow Creek to the Rio Grande River, the study area was separated into three separate tracer injections (fig. 1). Two injections were upstream from the town of Creede, Colorado. One was in West Willow Creek and started upstream from the Last Chance Mine and continued past the confluence with East Willow Creek to the streamflow-gaging station upstream from Creede. The second injection was in East Willow Creek, starting upstream from the Outlet Mine and continuing past the confluence with West Willow Creek to the same gaging station. The third injection started just downstream from the town of Creede and continued to the mouth of Willow Creek. It also included sampling sites in the Rio Grande River, upstream and downstream from Willow Creek. Much of this lower study reach included braids of Willow Creek and irrigation diversions. Area-velocity discharge measurements were included to supplement the discharge information from the tracer injection in that reach. 


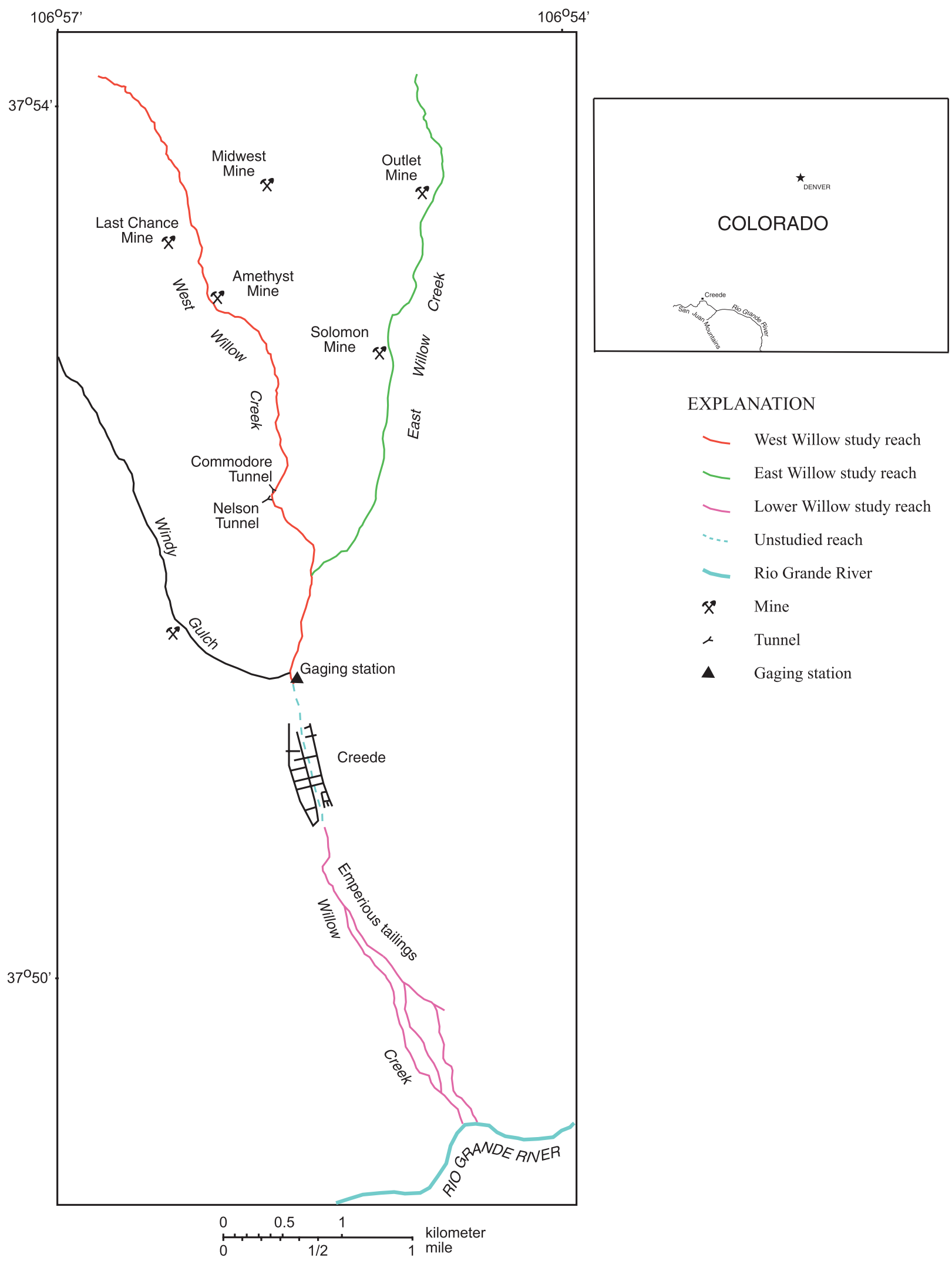

Figure 1. Location of the Willow Creek watershed, indicating study reaches for tracer-injection study reaches and principal mines along the study reach near Creede, Colorado. 


\section{Purpose and Scope}

This report presents the results of the three tracer injections in Willow Creek. The results will help determine where the greatest metal loading to the stream occurs, the extent of loading from dispersed, subsurface inflow to the stream, and the extent of metal attenuation from physical, chemical, and biological processes. The study treats the major ions calcium $(\mathrm{Ca})$, magnesium $(\mathrm{Mg})$, sodium $(\mathrm{Na})$, sulfate $\left(\mathrm{SO}_{4}\right)$, and bicarbonate (alkalinity as $\mathrm{CaCO}_{3}$ ), and the trace metals aluminum $(\mathrm{Al})$, cadmium $(\mathrm{Cd})$, copper $(\mathrm{Cu})$, iron $(\mathrm{Fe})$, manganese $(\mathrm{Mn})$, lead $(\mathrm{Pb})$, and zinc $(\mathrm{Zn})$.

\section{METHODS}

\section{Approach}

Application of the combined tracer-dilution and synoptic-sampling methods to abandoned mine lands has been developed as part of the U.S. Geological Survey's Toxic Substances Hydrology Program (Bencala and McKnight, 1987; Bencala and others, 1990; Broshears and others, 1993; Kimball and others, 1994; Kimball, 1997; Zellweger, 1994). As described below, the approach includes tracer injections to quantify discharge by tracer-dilution (Kilpatrick and Cobb, 1985) and synoptic sampling to provide spatial concentration profiles of $\mathrm{pH}$ and inorganic constituents. Discharge and concentration data are then combined to develop mass-loading curves.

The studies described below were undertaken during low-flow conditions in late summer for two reasons. First, the mass-loading pattern expressed at low flow reflects the importance of metal sources that enter the stream on a continuous basis. Remedial actions that address the sources identified at low flow will therefore improve water quality during the entire year. These sources can include mine waste sources such as waste rock piles, tailings piles, and mine workings and also drainage from adits, tunnels, or ground-water pathways to the stream. Some of these sources contribute water and solutes to the stream as distinct surface inflows, but some contribute water through dispersed, subsurface inflows to the stream. Second, the pattern of metal loading at low flow indicates which sources contribute to high concentrations during the winter months, when the most toxic conditions likely occur (Besser and Leib, 1999). During the low-flow winter months, mine drainage is less diluted by other sources of water, and limits of toxicity are more likely to be exceeded (Besser and others, 2001). Although dissolved metal loads are greater during snowmelt runoff, truly dissolved metal concentrations generally are lower, and the risk to aquatic life is not as great.

\section{Tracer Injections and Stream Discharge}

Quantifying discharge in mountain streams by the traditional velocity-area method (Rantz and others, 1982) is compromised because of the roughness of the streambed and the variability caused by pools and riffles (Jarrett, 1992). Further, a substantial percentage of discharge may be flowing through porous areas of the streambed that make up the hyporheic zone (Zellweger and others, 1989). Measurement of discharge with the velocity-area method does not account for flow through the hyporheic zone, and discharge estimates based on the velocity-area method may result in an underestimate of metal loads (Zellweger and others, 1989; Kimball and others, 2002). Another limitation of the velocity-area method for the characterization of metal loads is the time and personnel requirements associated with each discharge measurement. In the studies described below, numerous instream samples were collected during a single day to characterize stream chemistry at steady state. Velocity-area discharge measurements made in conjunction with sample collection at a large number of sites would be difficult, if not impossible.

An alternative means of estimating discharge that was used for this study is the tracer-dilution method (Kilpatrick and Cobb, 1985). With the tracerdilution method, an inert tracer is continuously injected into the stream at a constant rate and concentration. Given sufficient time, all of the stream, including side pools and the hyporheic zone, becomes saturated with tracer and instream concentration reaches a plateau (Bencala and others, 1990). Decreases in plateau concentration with stream length reflect the dilution of tracer by additional water entering the channel (surface and ground-water inflow). Consideration of this dilution allows for the calculation of discharge at each stream site. Application of the tracer-dilution method addresses both of the problems noted above: (1) the 
tracer enters porous areas of the streambed such that flow through the hyporheic zone is accounted for; and (2) collection of tracer samples when plateau concentration is achieved provides the ability to obtain discharge estimates at numerous locations during a short period.

Successful implementation of the tracer-dilution method is dependent on several key factors. First and foremost, the injected tracer must be transported through the stream system in a conservative manner; concentrations of the tracer should be unaffected by biogeochemical reactions. Potential tracers include dyes and inorganic salts. The degree to which a given tracer is conservative is often a function of stream $\mathrm{pH}$. Because of the circum-neutral $\mathrm{pH}$ of waters within the Willow Creek watershed, a sodium bromide $(\mathrm{NaBr})$ salt was used, and bromide (Br) was used as the conservative tracer. Another key factor is the ability to maintain a constant rate during the continuous tracer injection. For the study described below, tracer injections were controlled with precision metering pumps linked to a Campbell CR-10 data logger. Use of the data logger provides a means to maintain a constant injection rate as battery voltage decreases.

Kilpatrick and Cobb (1985) present a simple mass-balance equation used to determine discharge when fluorescent dyes are used to implement the tracer-dilution method. This equation is also applicable to the $\mathrm{Br}$ tracer as background $\mathrm{Br}$ concentrations in the Willow Creek watershed are uniform and much lower than that of the injected tracer (Kimball and others, 2002). Stream discharge at any location downstream from the injection site is therefore determined by:

$$
Q_{D}=\frac{Q_{I N J} C_{I N J}}{C_{D}-C_{B}}
$$

where

$Q_{D}$ is stream discharge, in $\mathrm{L} / \mathrm{s}$,

$Q_{I N J}$ is the injection rate, in $\mathrm{L} / \mathrm{s}$,

$C_{I N J}$ is the injectate concentration, in $\mathrm{mg} / \mathrm{L}$,

$C_{D}$ is the tracer concentration at plateau, in $\mathrm{mg} / \mathrm{L}$, and

$C_{B} \quad$ is the naturally occurring background concentration.

\section{Synoptic Sampling and Analytical Methods}

The spatial distribution of metal sources may be characterized by synoptic sampling. Under ideal conditions, samples at all of the sampling locations would be collected simultaneously, providing a description of stream water quality at steady state. Personnel limitations generally preclude simultaneous sample collection, but the synoptic studies described below provide an approximate means of describing steady-state conditions. This approximation is achieved by collecting samples over a relatively short time period (less than 8 hours) and by conducting the studies under low-flow conditions such that the effects of diurnal flow variation are minimized. By approximating steady-state conditions, synoptic sampling provides a spatially intensive "snapshot" of chemistry and discharge that is used to quantify instream loads.

During a synoptic study, samples are collected at a number of stream and inflow sites. Stream sites along the study reach are spaced such that they bracket the sampled inflows and areas of likely subsurface inflow. Subreaches that are bracketed by two adjacent stream sites are referred to as stream segments. The intent of this bracketing is to capture the changes in load that are attributable to visible surface inflow and (or) diffuse subsurface inflow within each segment. At this level of spatial detail, changes in stream chemistry and discharge between stream sampling sites reflect a net metal load for specific segments that incorporates all sources that reach the stream in that segment and instream reactions that affect metal concentrations. Loads for a particular segment cannot always be attributed to specific sources.

For each of the tracer injections described below, stream and inflow samples were collected at numerous predetermined locations, beginning at the downstream end of the study reach and ending upstream of the tracer-injection site. This downstream to upstream sampling order was followed to avoid disturbing streambed materials. Inflow and stream sites that were considered well mixed were sampled by using grab techniques. Sites that were not well mixed were sampled by equal-width integration (Ward and Harr, 1990). Water temperature was measured on site and the collected samples were transported to a central location for further processing. The collected samples were divided into several $125-\mathrm{mL}$ bottles at the central processing location: a raw (unfiltered) unacidified 
sample (RU), a raw acidified sample (RA), a filtered unacidified sample (FU), a filtered acidified sample (FA), and an ultra-filtered acidified sample (UFA).

Specific conductance and $\mathrm{pH}$ were determined from the RU sample within hours of sample collection. Tangential-flow filtration was used with $0.45-\mu \mathrm{m}$ membranes (FU and FA samples) and 10,000-Dalton molecular weight membranes (UFA sample, giving an effective pore size on the order of $0.001 \mu \mathrm{m}$ ). Metal concentrations for the RA, FA, and UFA samples were determined by inductively coupled plasma-atomic emission spectrometry (Lichte and others, 1987). Anion concentrations were determined from FU samples by using ion chromatography (Kimball and others, 1999). Ferrous iron was determined colorimetrically from the UFA (Kimball and others, 1992), and total alkalinity was determined by titration from the FU samples.

Use of two filtration techniques provides for three different operationally defined concentrations for each metal. The unfiltered sample (RA) provides a measure of the total-recoverable metal concentration (dissolved plus colloidal) and the ultrafiltrate concentration (UFA) is considered the dissolved metal concentration. The $0.45-\mu \mathrm{m}$ concentration (FA) is used to compare ultrafiltrate concentrations to aquatic standards that are written with $0.45-\mu \mathrm{m}$ filtration. Colloidal metal concentrations are defined as the difference between the total-recoverable (RA) and the ultrafiltrate metal concentrations (UFA) for stream samples (Kimball and others, 1995).

\section{Mass-Loading Analysis}

To quantify load requires accurate discharge and chemical measurements. Profiles of mass load along the study reach use three different views of load. Sampled instream load at individual sampling sites is calculated as:

$$
M_{a}=C_{a} Q_{a}(0.0864)
$$

where

$M_{a} \quad$ is the constituent load at location a, in $\mathrm{kg} /$ day,

$C_{a}$ is the concentration of the selected constituent at location a, in $\mathrm{mg} / \mathrm{L}$,

$Q_{a}$ is the discharge at location a, in $\mathrm{L} / \mathrm{s}$, and
0.0864 is the conversion factor from $\mathrm{mg} / \mathrm{s}$ to $\mathrm{kg} /$ day.

Sampled instream load is calculated from the total-recoverable concentration of the constituent, but this value for load can be divided between the dissolved and the colloidal load if both filtered and total-recoverable samples are collected. The longitudinal profile of sampled instream load is the basic data from the mass-loading study.

The change in load between a pair of stream sites, or for a stream segment, accounts for the gain or loss of constituent load for that segment. For the change in load for the segment starting at location a and ending at location $b$, we calculate:

$$
\Delta M_{s}=\left(C_{b} Q_{b}-C_{a} Q_{a}\right)(0.0864)
$$

where

$\Delta M_{S}$ is the change in sampled instream load for the segment from a to $\mathrm{b}$, in $\mathrm{kg} / \mathrm{day}$,

$C_{b}$ is the concentration of the selected constituent at location $\mathrm{b}$, in $\mathrm{mg} / \mathrm{L}$,

$Q_{b}$ is the discharge at location $\mathrm{b}$, in $\mathrm{L} / \mathrm{s}$,

$C_{a}$ and $Q_{a}$ are defined above, and

0.0864 is the conversion factor from $\mathrm{mg} / \mathrm{s}$ to $\mathrm{kg} /$ day.

Gains in constituent load $\left(\Delta M_{S}\right.$ is greater than zero) imply that there is a source that contributes to the stream between the two stream sites. Instream load also can decrease within a stream segment $\left(\Delta M_{S}\right.$ is less than zero), meaning that a net loss of the constituent occurred as a result of physical, chemical, or biological processes. Summing all the increases in load between sampling sites along the study reach (positive values of $\Delta M_{s}$ ) leads to the cumulative instream load. At the end of the study reach, the cumulative instream load is the best estimate of the total load added to the stream but is likely a minimum estimate because it only measures the net loading between sites and does not account for loss resulting from reaction. The cumulative instream load will be greater than the sampled instream load at the end of the study reach if there has been any loss of a constituent to the streambed.

For those segments that include a sampled inflow, it is possible to calculate a second value for load that is based upon the change in discharge between stream sites. This change, multiplied by constituent concentration in an inflow sample, produces an 
estimate of the inflow load for a stream segment. If stream sites a and b surround an inflow sample, location i:

$$
\Delta M_{i}=C_{i}\left(Q_{b}-Q_{a}\right)(0.0864)
$$

where

$\Delta M_{i}$ is the change in sampled inflow load from location a to $\mathrm{b}$, in $\mathrm{kg} / \mathrm{day}$,

$C_{i}$ is the concentration of the selected constituent at inflow location $\mathrm{i}$, in $\mathrm{mg} / \mathrm{L}$,

$Q_{b}$ and $Q_{a}$ are defined above, and

0.0864 is the conversion factor from $\mathrm{mg} / \mathrm{s}$ to $\mathrm{kg} /$ day.

Summing the inflow loads along the study reach produces a longitudinal profile of the cumulative inflow load. This sum can be compared to the cumulative instream load to indicate how well the sampled inflows account for the load measured in the stream. The cumulative instream and cumulative inflow profiles would be equal if the sampled inflows were representative of the constituent concentration for all the water entering the stream, but that is rarely the case. It is common in streams affected by mine drainage that dispersed, subsurface inflow can have higher concentrations of metals than the surface-water inflows in the same stream segment. This causes the profile of cumulative instream load to be greater than the profile of cumulative inflow load and can indicate important areas of unsampled inflow, which is defined as:

$$
\text { Unsampled inflow }=\Delta M_{S}-\Delta M_{i}
$$

Unsampled inflow can be calculated for individual stream segments if the segment included a sampled inflow, or for the entire study reach. If the value is negative for the entire study reach, however, it can still be positive for some individual stream segments.

In considering estimates of stream discharge and metal concentration at each stream site, it is possible to predict an error for the change in load along a stream segment. The error is determined by the precision of both discharge and chemical measurements (Taylor, 1997), according to an equation from McKinnon (2002):

$$
\text { Loaderror }=\left(\sqrt{Q_{a}^{2} \Delta C_{a}^{2}+C_{a}^{2} \Delta Q_{a}^{2}}\right)(0.0864)
$$

where

$Q_{a} \quad$ is the discharge at the upstream site, in $\mathrm{L} / \mathrm{s}$,

$\Delta C_{a} \quad$ is the concentration error at the upstream site, in $\mathrm{mg} / \mathrm{L}$,

$C_{a}$ is the concentration at the upstream site, in $\mathrm{mg} / \mathrm{L}$,

$\Delta Q_{a} \quad$ is the discharge error at the upstream site, and

0.0864 is the conversion factor from $\mathrm{mg} / \mathrm{s}$ to $\mathrm{kg} /$ day.

Load error can be calculated for each stream site and compared to the change in load from that site to the next site downstream, $\Delta M_{s}$. If $\Delta M_{s}$ is greater than the calculated load error, then there has been a significant change in load. Only the changes of instream load that are greater than the load error are included in the longitudinal profiles of sampled instream load and the cumulative instream load.

\section{Principal Components Analysis}

Synoptic sampling results in a large number of stream and inflow samples. Classification of these samples into groups of similar chemical characteristics helps highlight their similarities and differences. Because water-rock reactions with altered and unaltered mineral assemblages may lead to particular chemical signatures among inflows to the stream, the classification can help to distinguish different sources and also to recognize geochemical processes.

Patterns in the chemistry and $\mathrm{pH}$ of stream and inflow samples were evaluated by using Principal Components Analysis (PCA), a multivariate analysis technique (Daultrey, 1976; Joreskog and others, 1976). Principal components represent a set of new, transformed reference axes that are linear combinations of the original variables; it is a transformation of data, not a statistical treatment. A principal components transformation orients the data points so that the first of the new axes, principal component 1 (PC1), is oriented along the direction of the greatest variance in the data. The second principal component (PC2) is orthogonal to $\mathrm{PC} 1$ and is oriented to show the next greatest amount of variance in the data. This can be pictured in two dimensions if one imagines drawing a line that would go through the two most distant points in a bivariate plot of data; that would be the direction of PC1. It would be at some angle to the original $\mathrm{x}$ and $\mathrm{y}$ axes, but 
any point along the line could be described by a linear equation. PC2 would be drawn perpendicular to PC1 and would have its own linear equation. In multidimensional space, each subsequent principal component is orthogonal to the first two and represents a decreasing amount of the total variance.

Typically, the first two or three principal components show enough of the variance in the data set to enable the recognition of groups among samples; this is the advantage of using the method for multivariate data. Synoptic samples are plotted by their PCA scores, which are the coordinates of the original data points on the new principal component axes. Adding vectors representing the correlations of original variables with the new principal component axes to the plot of scores creates what is called a biplot. The vectors help identify variations in chemistry among the groups of samples. For the PCA analysis, totalrecoverable chemical concentrations, including $\mathrm{pH}$ (in millimoles per liter) were used after log transformation. Conversion to millimoles per liter and transformation to logs can maximize the linear relations among solutes that result from stoichiometric chemical reactions. Calculations were done using the U.S. Geological Survey STATPAC programs (Grundy and Miesch, 1985).

\section{EVALUATION OF METAL LOADING}

Results from the three tracer injections will be presented individually and the results can be combined for a discussion of watershed implications. A complete listing of the results of chemical analyses for synoptic samples is contained in the appendix. The tracerinjection study reaches in East and West Willow Creeks overlapped downstream from the confluence of the streams and both ended at the discontinued gaging station at the north end of Creede. This allowed for a comparison between the two reaches. The lower study reach started at the south end of Creede. The section of Willow Creek that was not included in a tracerinjection study reach flows through a concrete channel that extends through the town of Creede.

\section{West Willow Creek}

The tracer injection in West Willow Creek investigated a 6,602 $\mathrm{m}$ section of the Willow Creek watershed, starting upstream from the Last Chance Mine, and continuing past the confluence with East Willow Creek to the gaging station just upstream from the town of Creede (fig. 1). East Willow Creek was the only major surface-water inflow to the study reach, but there were many small seeps, springs, and minedrainage tunnels. Drainage from the Amethyst Mine, the Commodore Tunnel, and the Nelson Tunnel all entered the study reach. A reconnaissance geologic traverse was mapped in the field for much of this study reach and provides details of the near-stream geology and structure (Bruce Stover, Colorado Division of Minerals and Geology, written commun., 2000).

The 6,602-m study reach was divided into 34 segments by the stream sampling sites (fig. 2). Stream segments bracketed eight major and minor tributary inflows and areas of likely subsurface inflow. Site designations for stream segments came from the previous studies of the stakeholder group: sites WW-A through WW-L, in an upstream direction. Additional sites use the designations for West Willow (WW), East Willow (EW), and lower Willow (LW) along with the measured downstream distance to the site. Downstream distance in East Willow Creek continued past the confluence with West Willow Creek all the way to the Rio Grande River. Distances in West Willow Creek only went as far as the confluence with East Willow Creek. Site designations and information about the sampling sites in West Willow Creek are listed in table 1. In choosing stream-sampling sites, locations were selected that should be sufficiently downstream from inflows to capture both visible tributary inflow and additional subsurface inflow. Only eight stream segments contained sampled inflows; the other segments represented dispersed, subsurface inflow. 


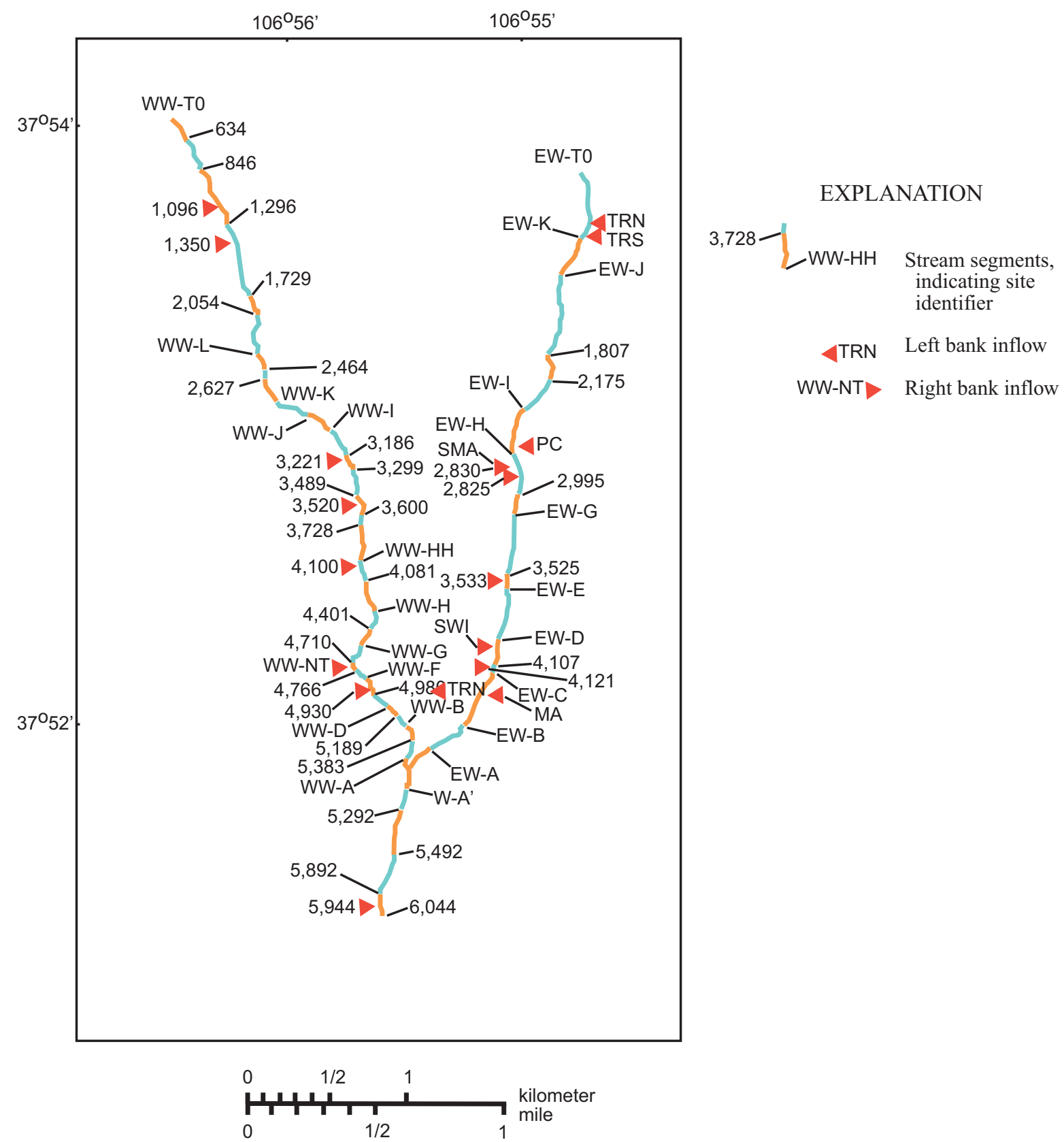

Figure 2. Location of stream segments and inflow samples for East and West Willow Creeks, Colorado. Colors indicate the different stream segments. 
Table 1. Sample identification, source, distance along the injection study reach, site description, pH, specific conductance, tracer concentration, and calculated discharge for synoptic samples from West Willow Creek, Colorado, September 2000

\begin{tabular}{|c|c|c|c|c|c|c|c|}
\hline $\begin{array}{c}\text { Sample } \\
\text { identifi- } \\
\text { cation }\end{array}$ & Source & $\begin{array}{l}\text { Down- } \\
\text { stream } \\
\text { distance, } \\
\text { in meters }\end{array}$ & Site description & $\begin{array}{c}\mathrm{pH}, \\
\text { in } \\
\text { standard } \\
\text { units }\end{array}$ & $\begin{array}{c}\text { Specific } \\
\text { conductance, in } \\
\text { microsiemens } \\
\text { per centimeter }\end{array}$ & $\begin{array}{c}\text { Bromide } \\
\text { concentration, in } \\
\text { milligrams per } \\
\text { liter }\end{array}$ & $\begin{array}{l}\text { Calculated } \\
\text { discharge, } \\
\text { in liters per } \\
\text { second }\end{array}$ \\
\hline WW-430 & Stream & 430 & T0 - Above injection site & 7.91 & 105 & 0.09 & 92 \\
\hline WW-634 & Stream & 634 & T1 - First site below injection site & 8.02 & 111 & 4.07 & 92 \\
\hline WW-846 & Stream & 846 & West Willow Creek where gradient increases & 8.11 & 111 & 4.07 & 92 \\
\hline WW-1096 & Inflow & 1,096 & Drainage from gully & 6.75 & 58 & & .10 \\
\hline WW-1296 & Stream & 1,296 & Below rhyolite outcrop & 8.09 & 111 & 4.07 & 92 \\
\hline WW-1350 & Inflow & 1,350 & Left bank inflow & 6.99 & 95 & & .10 \\
\hline WW-1729 & Stream & 1,729 & Stream site to check mixing of tracer & 8.08 & 110 & 4.07 & 92 \\
\hline WW-2054 & Stream & 2,054 & Last site in moraine deposits & 7.97 & 111 & 3.98 & 95 \\
\hline WW-L & Stream & 2,304 & Stakeholder site above Last Chance Mine & 8.01 & 111 & 3.83 & 100 \\
\hline WW-2464 & Stream & 2,464 & Above Last Chance talus pile & 7.86 & 111 & 3.83 & 100 \\
\hline WW-2627 & Stream & 2,627 & Above Amethyst Tunnel & 7.93 & 111 & 3.83 & 100 \\
\hline WW-K & Stream & 2,667 & Below Amethyst Tunnel & 7.95 & 111 & 3.80 & 100 \\
\hline WW-J & Stream & 2,829 & T2 - Above Nelson Creek & 7.99 & 112 & 3.74 & 106 \\
\hline NC-E & Inflow & 2,847 & Nelson Creek above Midwest Mine & & & & \\
\hline NC-B & Inflow & 2,847 & Nelson Creek at mouth & & & & \\
\hline WW-I & Stream & 3,021 & Below Nelson Creek & 7.97 & 112 & 3.66 & 106 \\
\hline WW-3186 & Stream & 3,186 & $\begin{array}{l}\text { West Willow Creek above right bank spring } \\
\text { at fault }\end{array}$ & 7.94 & 112 & 3.55 & 110 \\
\hline WW-3221 & Inflow & 3,221 & Spring from fault & 6.92 & 101 & & 4 \\
\hline WW-3299 & Stream & 3,299 & West Willow Creek at rhyolite outcrop & 7.91 & 112 & 3.45 & 114 \\
\hline WW-3489 & Stream & 3,489 & West Willow Creek at log waterfall & 7.87 & 110 & 3.41 & 116 \\
\hline WW-3520 & Inflow & 3,520 & Spring near stream level on right bank & 7.13 & 90 & & 1 \\
\hline WW-3600 & Stream & 3,600 & West Willow Creek at top of cascades & 7.96 & 110 & 3.38 & 117 \\
\hline WW-3728 & Stream & 3,728 & $\begin{array}{l}\text { West Willow Creek at culvert above Burro } \\
\text { Bridge }\end{array}$ & 7.94 & 110 & 3.36 & 118 \\
\hline WW-HH & Stream & 3,858 & West Willow Creek at Burro Bridge & 7.96 & 110 & 3.32 & 120 \\
\hline WW-4100 & Inflow & 3,885 & Water coming off rock face & 7.73 & 32 & & 2 \\
\hline WW-4081 & Stream & 4,081 & West Willow Creek below Burro Bridge & 7.94 & 110 & 3.27 & 122 \\
\hline WW-H & Stream & 4,245 & West Willow Creek in cascades & 7.88 & 109 & 3.18 & 126 \\
\hline WW-4401 & Stream & 4,401 & $\begin{array}{l}100 \text { meters above old buildings by } \\
\text { Commodore Tunnel }\end{array}$ & 7.93 & 109 & 3.15 & 128 \\
\hline WW-G & Stream & 4,577 & $\begin{array}{l}\text { West Willow Creek above Commodore } \\
\text { Tunnel }\end{array}$ & 7.91 & 109 & 3.09 & 131 \\
\hline WW-4710 & Stream & 4,710 & Above Nelson Tunnel & 7.73 & 109 & 3.09 & 131 \\
\hline WW-NT & Inflow & 4,730 & Nelson Tunnel discharge & 4.45 & 1,521 & & 22 \\
\hline WW-F & Stream & 4,766 & $\begin{array}{l}\text { West Willow Creek down from Nelson } \\
\text { Tunnel (not WW-F) }\end{array}$ & 7.26 & 328 & 2.72 & 153 \\
\hline WW-4866 & Stream & 4,866 & West Willow Creek below culvert & 7.37 & 344 & 2.63 & 158 \\
\hline WW-4930 & Inflow & 4,930 & $\begin{array}{l}\text { Spring on right bank with aluminum } \\
\text { precipitate }\end{array}$ & 5.46 & 646 & & 5 \\
\hline WW-4980 & Stream & 4,980 & Below Commodore mine dump & 7.30 & 351 & 2.57 & 163 \\
\hline WW-D & Stream & 5,063 & West Willow Creek below mine dump & 7.74 & 349 & 2.55 & 164 \\
\hline WW-5189 & Stream & 5,189 & West Willow Creek at point of good mixing & 7.77 & 349 & 2.55 & 131 \\
\hline
\end{tabular}


Table 1. Sample identification, source, distance along the injection study reach, site description, pH, specific conductance, tracer concentration, and calculated discharge for synoptic samples from West Willow Creek, Colorado, September 2000—Continued

\begin{tabular}{|c|c|c|c|c|c|c|c|}
\hline $\begin{array}{c}\text { Sample } \\
\text { identifi- } \\
\text { cation }\end{array}$ & Source & $\begin{array}{l}\text { Down- } \\
\text { stream } \\
\text { distance, } \\
\text { in meters }\end{array}$ & Site description & $\begin{array}{c}\mathrm{pH}, \\
\text { in } \\
\text { standard } \\
\text { units }\end{array}$ & $\begin{array}{c}\text { Specific } \\
\text { conductance, in } \\
\text { microsiemens } \\
\text { per centimeter }\end{array}$ & $\begin{array}{c}\text { Bromide } \\
\text { concentration, in } \\
\text { milligrams per } \\
\text { liter }\end{array}$ & $\begin{array}{c}\text { Calculated } \\
\text { discharge, } \\
\text { in liters per } \\
\text { second }\end{array}$ \\
\hline WW-B & Stream & 5,282 & $\begin{array}{l}\text { West Willow Creek up from bridge at photo } \\
\text { stop }\end{array}$ & 7.75 & 350 & 2.55 & 131 \\
\hline WW-5383 & Stream & 5,383 & $\begin{array}{l}\text { West Willow Creek above possible Amethyst } \\
\text { Fault }\end{array}$ & 7.72 & 349 & 2.53 & 132 \\
\hline WW-A & Stream & 5,540 & T3 - West Willow Creek above confluence & 7.64 & 350 & 2.49 & 135 \\
\hline EW-A & Inflow & 5,614 & East Willow Creek near mouth & 8.01 & 53 & .03 & 434 \\
\hline W-A & Stream & 5,716 & Willow Creek down from confluence & 7.82 & 145 & .7 & 568 \\
\hline EW-5892 & Stream & 6,450 & Willow Creek above pond near Windy Gulch & 7.46 & 147 & .7 & 568 \\
\hline EW-6044 & Stream & 6,602 & $\begin{array}{l}\text { Willow Creek down from Windy Gulch at } \\
\text { gage }\end{array}$ & 7.59 & 146 & .7 & 568 \\
\hline
\end{tabular}

\section{Discharge}

Precision for the $\mathrm{Br}$ analyses was better than 1 percent over the range of concentrations. This allows the detection of very small changes in discharge. In a cascading, cobble-bottom stream like West Willow Creek, an area-velocity measurement might have a precision closer to 20 percent, or as much as $28 \mathrm{~L} / \mathrm{s}$. A $\mathrm{NaBr}$ tracer with a $\mathrm{Br}$ concentration of $145,250 \mathrm{mg} / \mathrm{L}$ was injected at a rate of $0.0034 \mathrm{~L} / \mathrm{s}$. The systematic decrease of $\mathrm{Br}$ concentration downstream from the injection site allowed the calculation of discharge at each of the stream sampling sites (fig. 3). There were no inflows with $\mathrm{Br}$ concentrations above the lower detection limit. Thus, with a uniform background concentration of tracer, equation 1 can be used to calculate discharge for the stream sites. The change in discharge for each stream segment represents the combination of surface and subsurface inflow to the stream and is the total inflow discharge for a given stream segment. The increase in discharge along the study reach was $476 \mathrm{~L} / \mathrm{s}$. Only about 7 percent of the increase in discharge was from segments that had no sampled inflow. However, subtracting the surfacewater inflow from East Willow Creek, about 55 percent of the remaining increase in discharge along West Willow Creek was from unsampled inflow.

The Amethyst Fault intersects West Willow Creek in the vicinity of stream site WW-5189 (Bruce Stover, Colorado Division of Minerals and Geology, written commun., 2000). The Amethyst Fault trends north-northwest and has a dip of 50 to 70 degrees southwest (Steven and Ratté, 1965). Area-velocity measurements made upstream and downstream from the area of the fault indicated a loss of $34 \mathrm{~L} / \mathrm{s}$ in that segment of the stream. A loss of water would result in a constant tracer constant, and tracer concentrations remained constant in segments WW-D through WW-B. So the tracer pattern is consistent with a measured loss of streamflow. The discharge profile reflects this loss of streamflow at WW-5189 (fig. 3).

\section{Chemical Characterization of Synoptic Samples}

Synoptic sampling of inflows provides the range of chemistry affecting the stream and provides a context for understanding the changes in stream chemistry and solute loads. Water-rock interactions with bedrock throughout the watershed can generate inflows that are affected by acid rock drainage as well as inflows that are affected by rocks that have acidneutralizing capacity. Thus, inflow chemistry can range from acidic and metal-rich to alkaline and essentially metal-free and both kinds of inflow chemistries can affect the stream chemistry.

Streamwater at the injection point in West Willow Creek was a $\mathrm{CaHCO}_{3}-\mathrm{CaSO}_{4}$ type water, reflecting the chemical weathering of bedrock in the watershed (Steven and Ratté, 1965). Both major ions and $\mathrm{pH}$ remained nearly constant along the study reach from the injection site until the inflow of the Nelson Tunnel at WW-F (fig. 4). At that point, the chemical character changed to a $\mathrm{CaSO}_{4}$ type, and $\mathrm{pH}$ was lower. With the inflow of East Willow Creek, at W-A', 


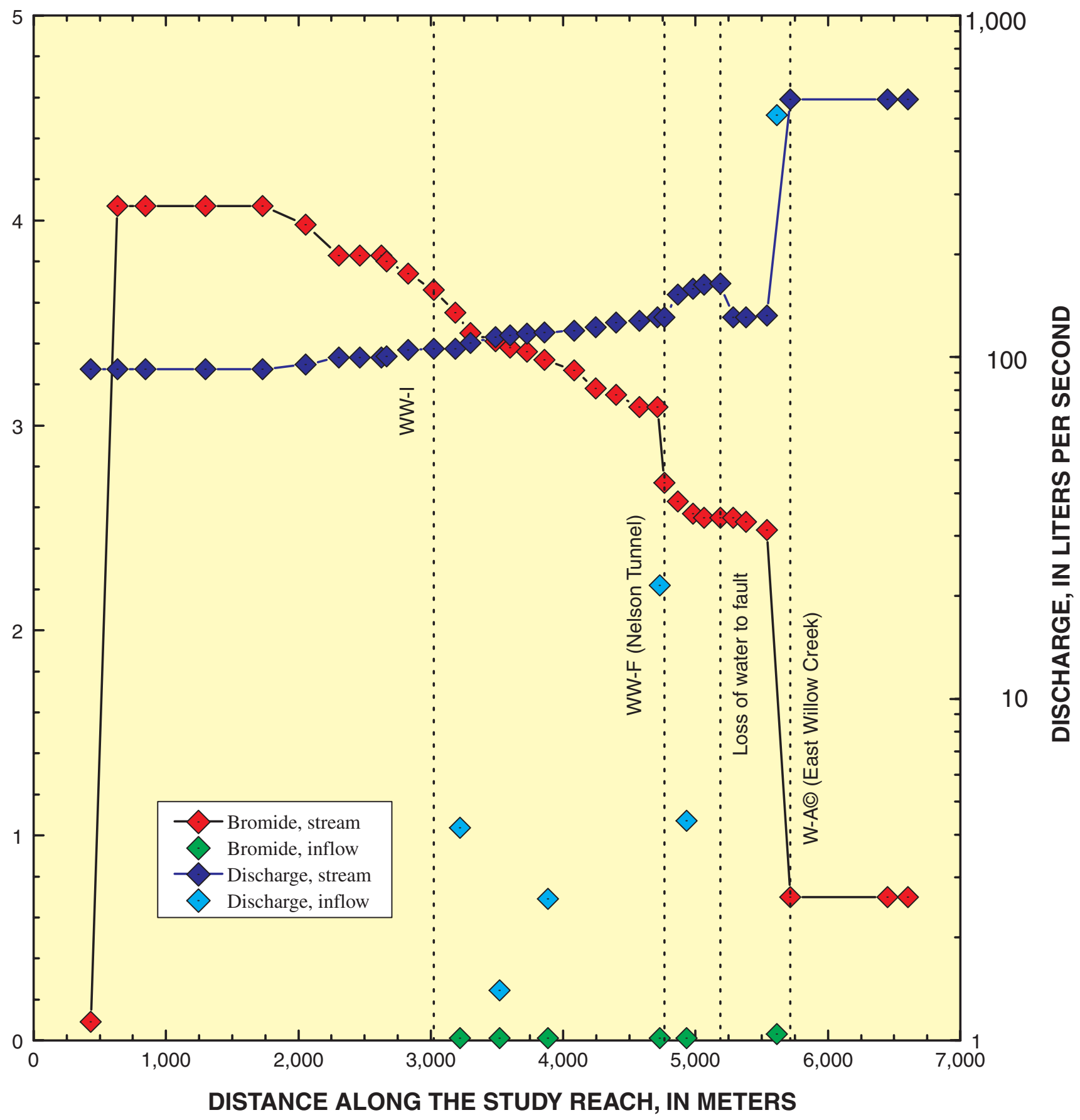

Figure 3. Variaton of bromide concentration and calculated discharge with distance along the study reach, West Willow Creek, Colorado, September 2000. 

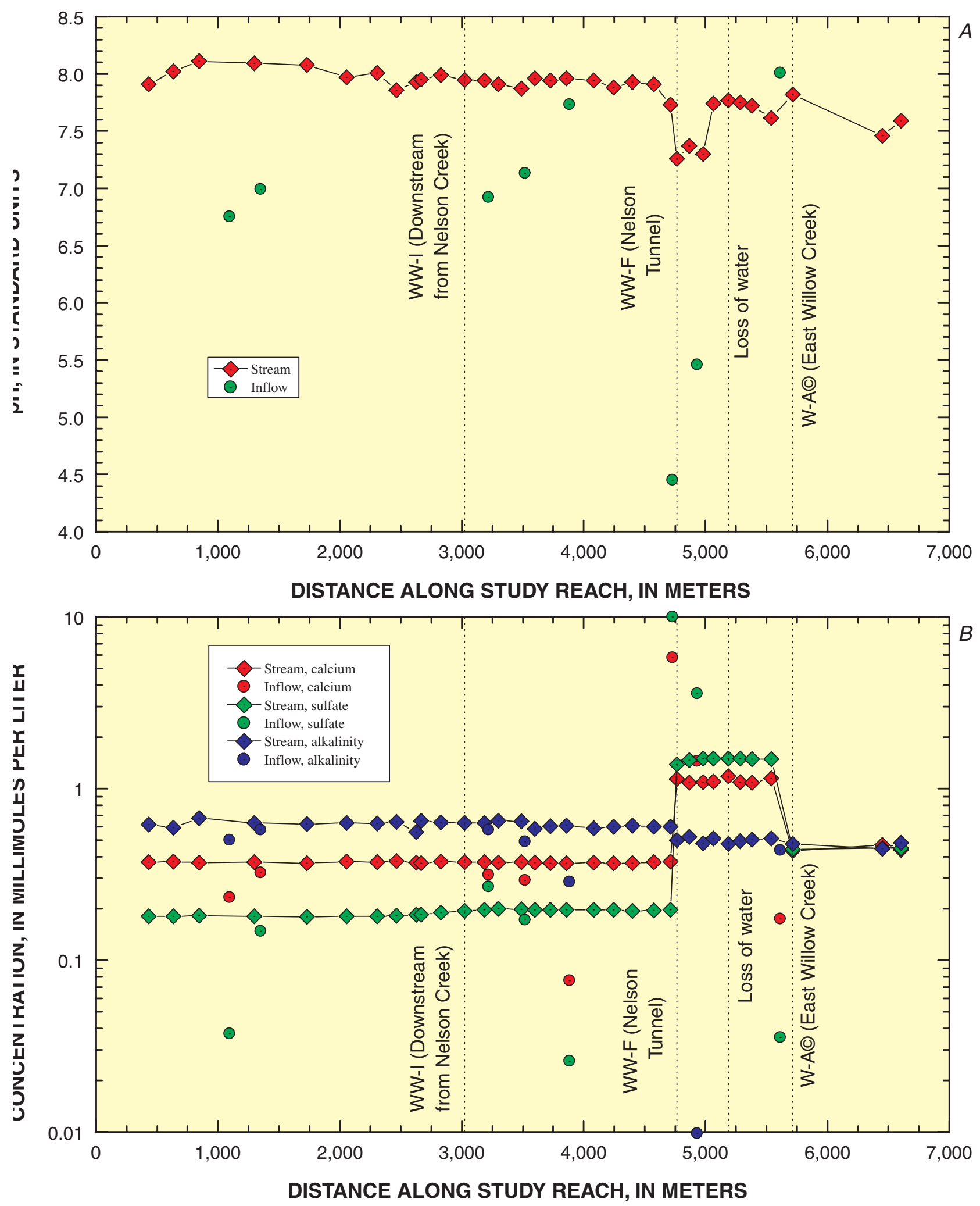

Figure 4. Variation of $(\mathrm{A}) \mathrm{pH}$ and $(\mathrm{B})$ calcium, sulfate, and alkalinity concentration with distance along the study reach, West Willow Creek, Colorado, September 2000. 
pH became more basic again; $\mathrm{Ca}$ and $\mathrm{SO}_{4}$ were diluted, and alkalinity remained nearly constant.

Several metals were present in relatively high concentrations, most notably $\mathrm{Fe}, \mathrm{Mn}, \mathrm{Pb}, \mathrm{Sr}$, and $\mathrm{Zn}$ (fig. 5). Dissolved Al, dissolved Fe, and nickel (Ni) mostly were near limits of detection, but colloidal concentrations of $\mathrm{Al}$ and $\mathrm{Fe}$ were measurable along most of the study reach. Colloidal $\mathrm{Pb}$ concentrations generally were higher than dissolved $\mathrm{Pb}$ concentrations, but both collodial and dissolved concentrations of $\mathrm{Pb}$ were relatively high compared to many streams affected by mine drainage. Although no great variation in major-ion concentrations or $\mathrm{pH}$ occurred along the study reach (fig. 4), a substantial difference in metal concentrations upstream and downstream from the Nelson Tunnel did occur, with higher concentrations occurring downstream.

A substantial amount of spatial variation in $\mathrm{Al}$ concentrations occurred (fig. 6). From the injection site to the Nelson Tunnel, which entered in segment WW-F, both the ultrafiltrate and $0.45-\mu \mathrm{m}$ filtered concentrations were less than detection. Only the totalrecoverable concentration was measurable, but a considerable amount of analytical variation occurred with the ICP-AES analysis for Al concentrations less than $0.1 \mathrm{mg} / \mathrm{L}$. With the inflow of the Nelson Tunnel at WW-F, total-recoverable and $0.45-\mu \mathrm{m}$-filtered concentrations increased, while the ultrafiltrate concentration remained low. Between the Nelson Tunnel inflow and the inflow of East Willow Creek at W-A', a distinct difference occurred between the ultrafiltrate and the $0.45-\mu \mathrm{m}$ filtered concentrations, indicating the possible distribution in size of the colloidal particles. Downstream from the inflow of East Willow Creek, an even more clear distinction occurred, and the ultrafiltrate and the $0.45-\mu \mathrm{m}$ filtered concentrations were again near the lower detection limit for analysis.

Ultrafiltrate Fe concentrations essentially were less than detection along the entire study reach (fig. 7). However, the 0.45 - $\mu \mathrm{m}$ filtrate concentrations were measurable and followed the pattern of totalrecoverable Fe concentrations. The clear distinction between total-recoverable and ultrafiltrate $\mathrm{Fe}$ concentrations indicates the presence of colloidal Fe. As with $\mathrm{Al}$, the difference between total-recoverable and $0.45-\mu \mathrm{m}$ concentrations indicates the size distribution of colloidal particles, but also indicates the importance of ultrafiltration to determine truly dissolved $\mathrm{Fe}$ concentrations in a stream affected by mine drainage.

The importance of the $\mathrm{Fe}$ and $\mathrm{Al}$ colloids is seen by their effect on other metals. Zinc and $\mathrm{Cu}$ sorb to the Fe hydroxides (Runkel and others, 1999). The presence of $\mathrm{Cu}$ and $\mathrm{Zn}$ in the colloidal material could have effects on the chronic toxicity of the stream (Clements, 1994; Besser and others, 2001). Colloidal concentrations contribute to the high concentrations of $\mathrm{Cu}$ and $\mathrm{Zn}$ in the bed sediments of many streams affected by mine drainage (Kimball and others, 2002).

The pattern of $\mathrm{Zn}$ concentration in each of the filtrations differed substantially from the patterns of $\mathrm{Al}$ and $\mathrm{Fe}$. Concentrations of $\mathrm{Zn}$ were essentially near detection from the beginning of the study reach to the area near the Amethyst Mine, where concentrations increased to more than $0.2 \mathrm{mg} / \mathrm{L}$ (fig. 8). Downstream from the inflow of the Nelson Tunnel at WW-4766, Zn concentration increased to more than $10 \mathrm{mg} / \mathrm{L}$. The Nelson Tunnel inflow caused all the filtrate concentrations to increase, and they all decreased with the inflow of East Willow Creek at W-A'. This pattern indicates that $\mathrm{Zn}$ occurred in the dissolved, rather than the colloidal, phase. The concentration profile of $\mathrm{Mn}$ was very similar to that of $\mathrm{Zn}$, but the concentration of Mn did not increase until inflow of the Nelson Tunnel joined the flow.

All the variations in stream chemistry are summarized in the biplot of principal component scores and loadings (fig. 9). Each of the chemical constituents used in the analysis is represented by an arrow, or vector, in the biplot. Each vector points in the direction of increasing concentration for a given constituent. For example, all the constituents except $\mathrm{Fe}$ increase from left to right on the diagram. The value of $\mathrm{pH}$ decreases (direction of increasing hydrogen ion concentration) in the direction of WW-NT and WW4930 (group 6). Thus, the change along the PC1 axis represents the effects of mine drainage, namely, the lowering of $\mathrm{pH}$ and the increase of metal concentrations. Changes along the PC2 axis mostly represent variations in $\mathrm{Fe}$ concentration, but $\mathrm{Al}$ concentration also increases slightly in that direction. Note that total-recoverable Fe was used in the PCA, therefore this includes dissolved plus colloidal concentrations. 


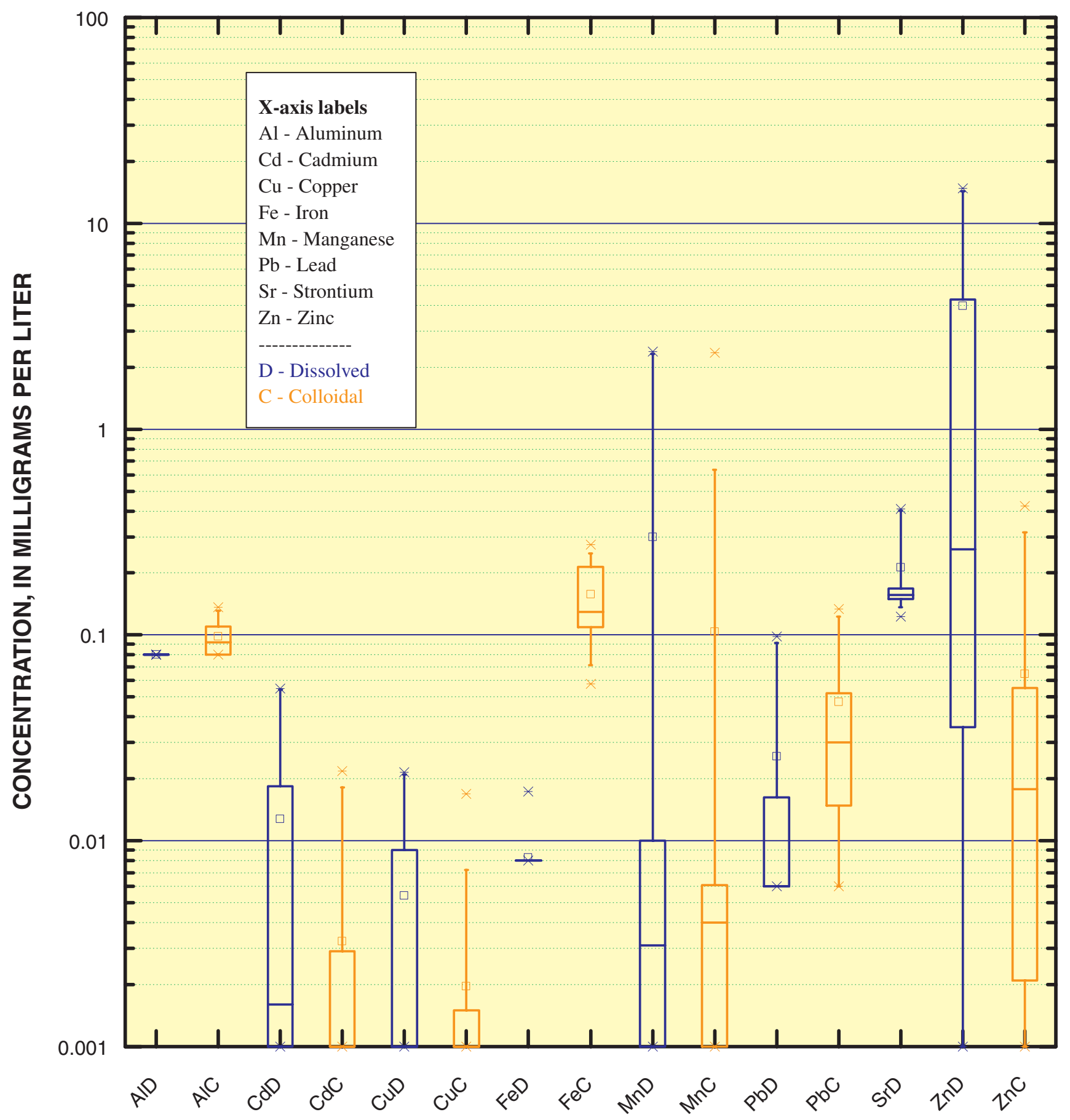

Figure 5. Distribution of dissolved (blue) and collodial (orange) metal concentrations in synoptic stream samples, West Willow Creek, Colorado, September 2000. 


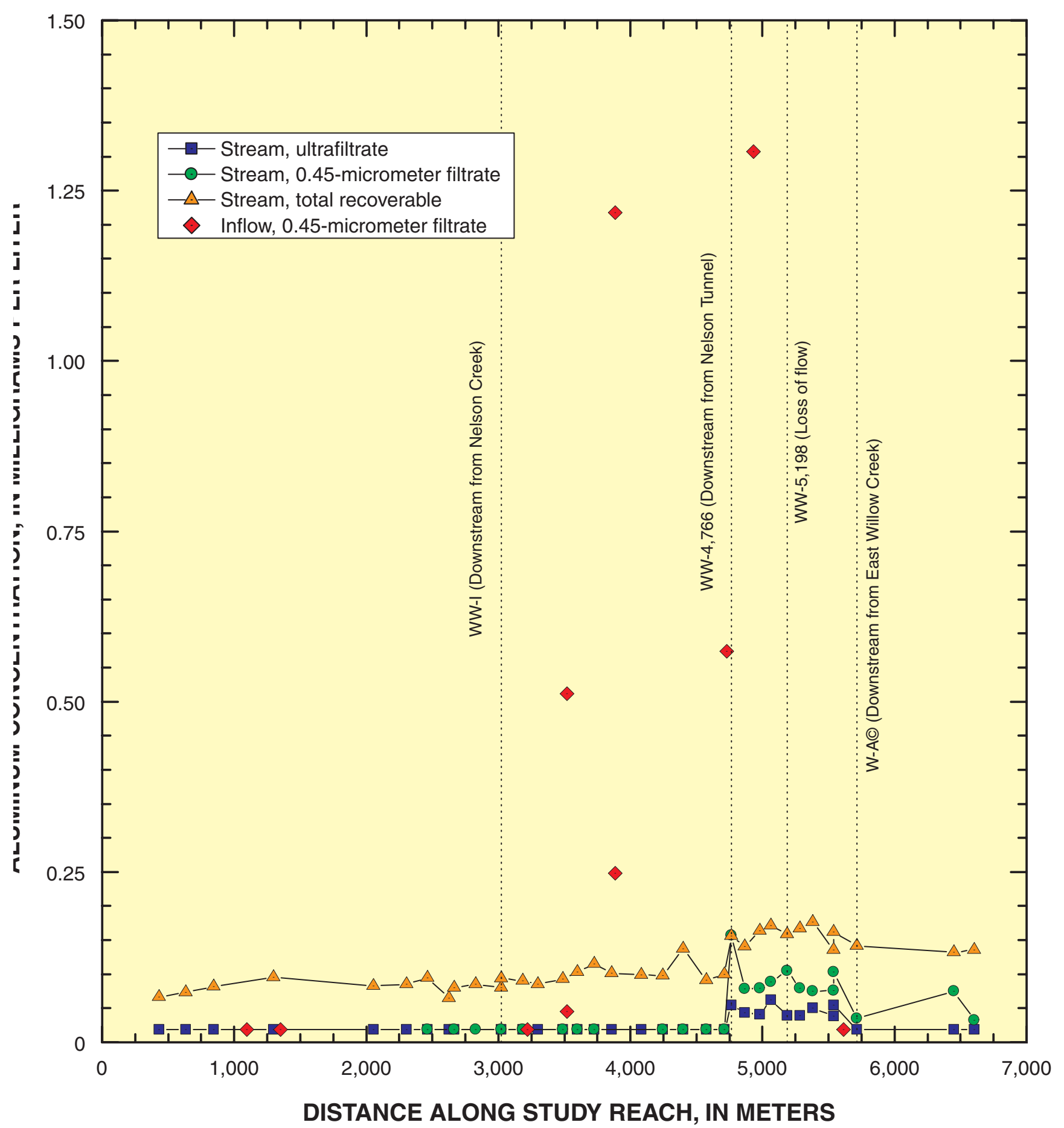

Figure 6. Variation of aluminum concentration in ultrafiltrate, $0.45-\mu \mathrm{m}$ filtered, and total-recoverable samples with distance along the study reach, West Willow Creek, Colorado, September 2000. 


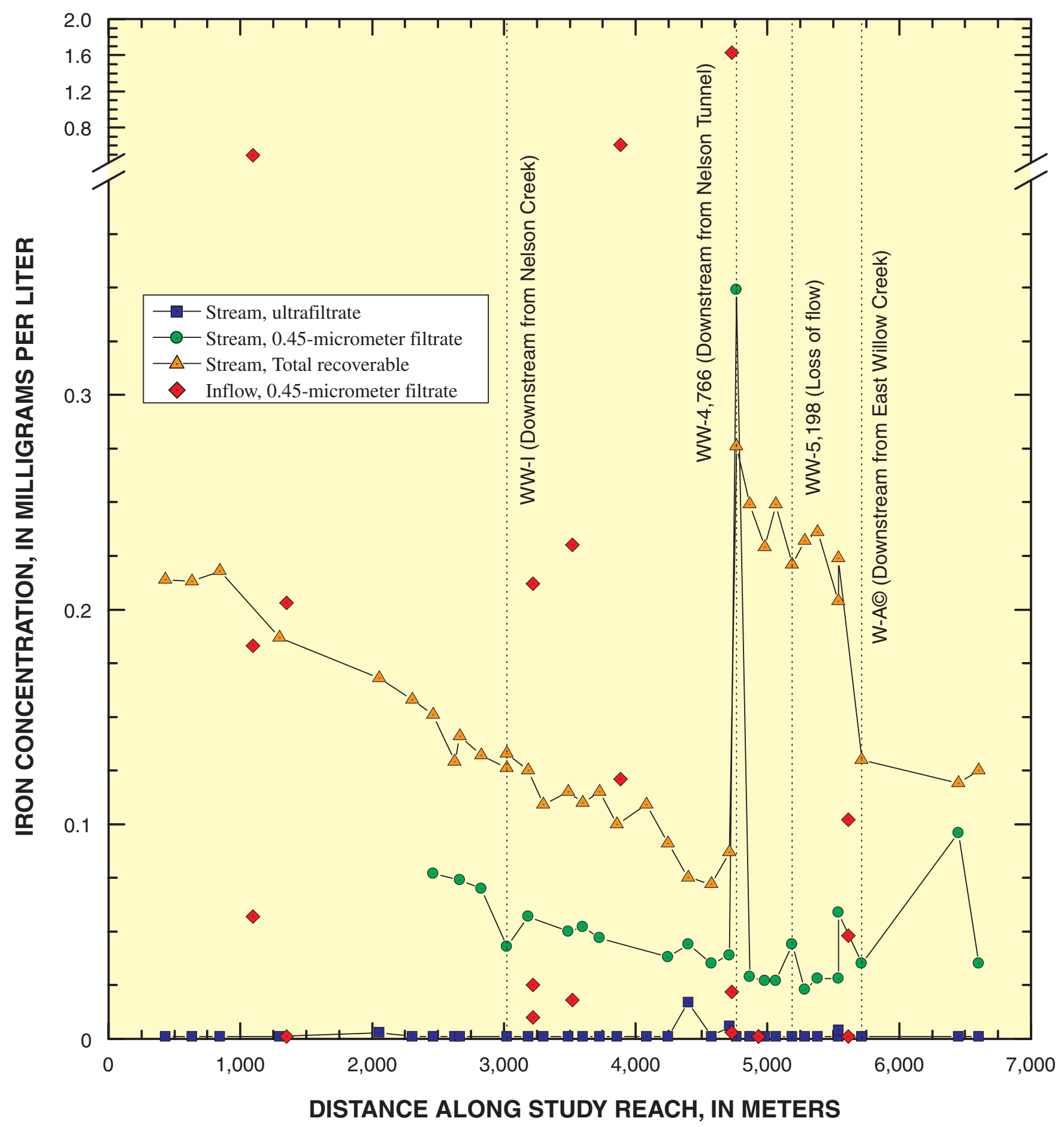

Figure 7. Variation of iron concentration in ultrafiltrate, $0.45-\mu \mathrm{m}$ filtered, and total-recoverable samples with distance along the study reach, West Willow Creek, Colorado, September 2000. 


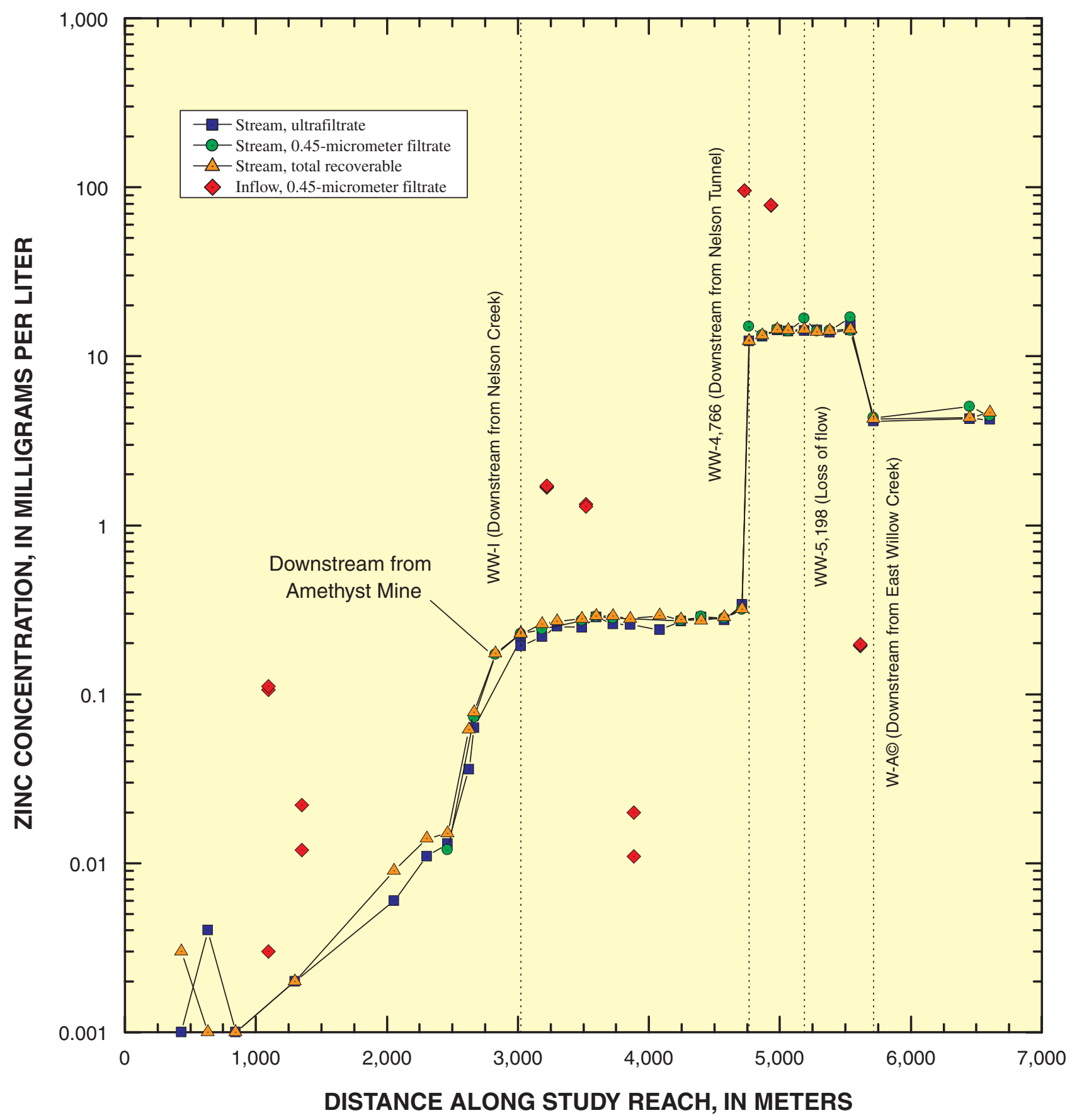

Figure 8. Variation of zinc concentration in ultrafiltrate, $0.45-\mu \mathrm{m}$ filtered, and total-recoverable samples with distance along the study reach, West Willow Creek, Colorado, September 2000. 
SCALED PRINCIPAL COMPONENT 1 LOADINGS

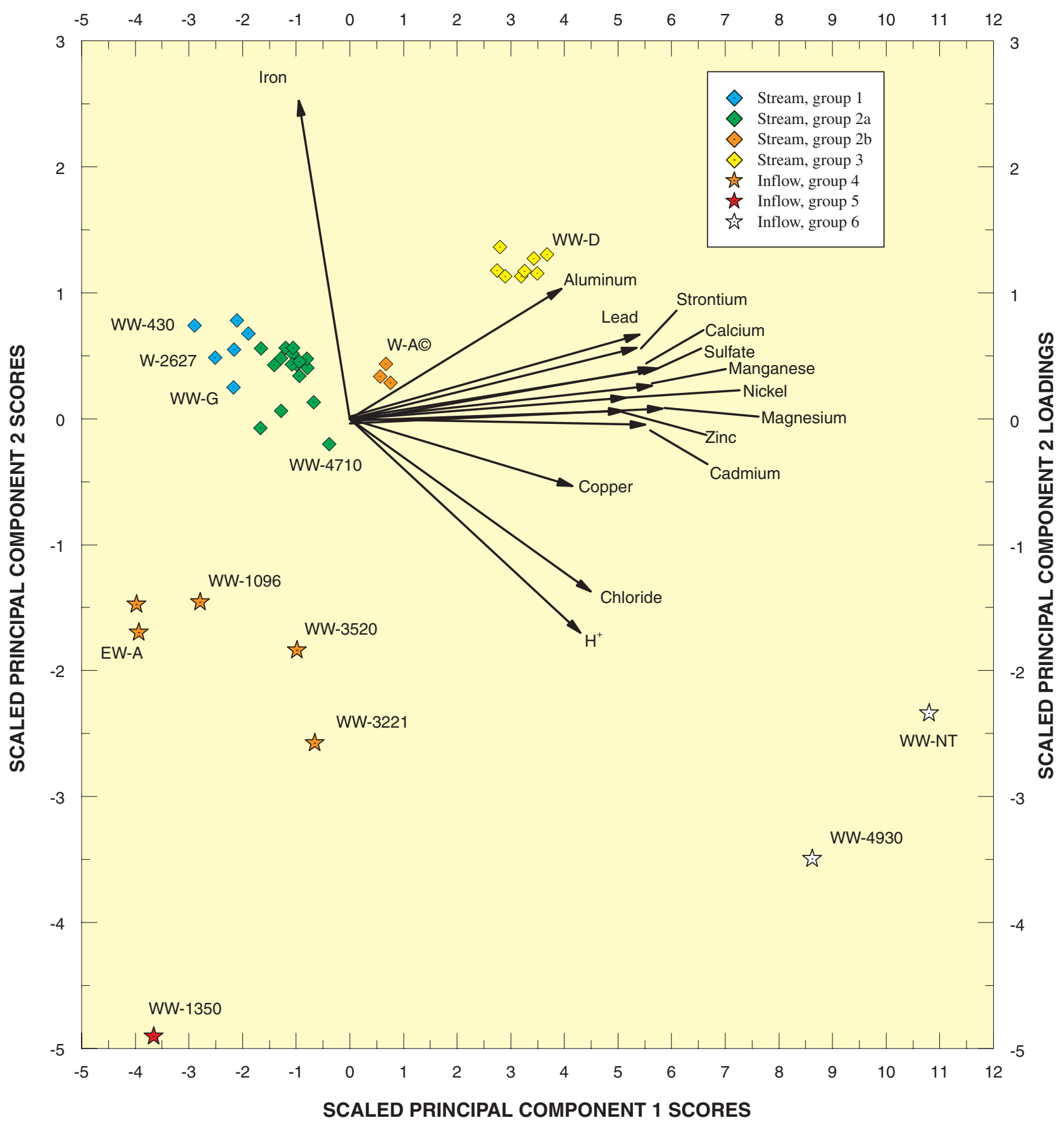

Figure 9. Biplot of principal component scores for synoptic samples and loadings for chemical constituents, West Willow Creek, Colorado, September 2000. 
Within this framework of chemical changes, the classification of samples into the different groups indicates important changes along the study reach. Three groups of stream samples and three groups of inflow samples were distinguished (table 2). Stream samples of group 1 have the lowest concentrations of all the stream samples and represent water unaffected by mine drainage. In a sense, this group is like an inflow group, indicating the composition of recharge waters at the head of the stream. Inflows of group 4 also plot far to the left of the biplot and have relatively low concentrations of all the constituents. A unique sample, WW-1350, was sufficiently different to be considered separately as group 5, and had the lowest concentrations of all the constituents, but a lower $\mathrm{pH}$. Two inflow samples make up group 6; these had the highest concentrations and lowest $\mathrm{pH}$ values among all the inflow samples. The effects of these inflow groups on the stream samples is evident by changes among groups of stream samples.

Table 2. Median composition of stream and inflow groups distinguished by principal components analysis, West Willow Creek, Colorado, September 2000

[Dis, dissolved; Col, colloidal; mg/L, milligrams per liter; LD, less than detection limit]

\begin{tabular}{|c|c|c|c|c|c|c|c|c|}
\hline Constituent & Phase & $\begin{array}{c}\text { Group } 1 \\
\text { Stream- } \\
\text { headwater } \\
\text { samples }\end{array}$ & $\begin{array}{l}\text { Group 2a } \\
\text { Stream from } \\
\text { Amethyst } \\
\text { Mine to } \\
\text { Nelson } \\
\text { Tunnel }\end{array}$ & $\begin{array}{c}\text { Group 2b } \\
\text { downstream } \\
\text { from East } \\
\text { Willow } \\
\text { Creek }\end{array}$ & $\begin{array}{c}\text { Group } 3 \\
\text { Stream from } \\
\text { Nelson } \\
\text { Tunnel to } \\
\text { East Willow } \\
\text { Creek }\end{array}$ & $\begin{array}{c}\text { Group } 4 \\
\text { Inflows- } \\
\text { Dilute }\end{array}$ & $\begin{array}{c}\text { Group } 5 \\
\text { Inflow WW- } \\
1350\end{array}$ & $\begin{array}{c}\text { Group } 6 \\
\text { Inflows- } \\
\text { Nelson } \\
\text { Tunnel and } \\
\text { WW-4930 } \\
\text { spring }\end{array}$ \\
\hline $\mathrm{pH}$, in standard units & Dis & 8.02 & 7.94 & 7.59 & 7.67 & 7.13 & 6.99 & 4.96 \\
\hline Calcium, in mg/L & Dis & 14.9 & 14.9 & 17.6 & 43.9 & 9.27 & 12.9 & 145 \\
\hline Magnesium, in mg/L & Dis & 1.60 & 1.65 & 1.69 & 3.89 & 1.30 & 1.51 & 12.8 \\
\hline Sodium, in mg/L & Dis & 4.15 & 3.81 & 4.66 & 10.1 & 2.47 & 2.86 & 33.2 \\
\hline Chloride, in mg/L & Dis & .160 & .170 & .220 & .278 & .260 & .240 & 1.13 \\
\hline Sulfate, in $\mathrm{mg} / \mathrm{L}$ & Dis & 17.3 & 18.9 & 43.1 & 143 & 3.58 & 14.2 & 653 \\
\hline Alkalinity, in $\mathrm{mg} / \mathrm{L}$ as $\mathrm{CaCO}_{3}$ & Dis & 31.1 & 31.0 & 23.8 & 25.2 & 24.5 & 28.8 & .245 \\
\hline Silica, in $\mathrm{mg} / \mathrm{L}$ & Dis & 17.0 & 17.3 & 19.2 & 18.1 & 17.8 & 17.3 & 28.2 \\
\hline \multirow[t]{2}{*}{ Aluminum, in mg/L } & Dis & .007 & .006 & .022 & .045 & .032 & LD & .988 \\
\hline & $\mathrm{Col}$ & .061 & .090 & .120 & .115 & .032 & LD & .988 \\
\hline \multirow[t]{2}{*}{ Cadmium, in $\mathrm{mg} / \mathrm{L}$} & Dis & .001 & .001 & .018 & .038 & .003 & LD & .388 \\
\hline & $\mathrm{Col}$ & LD & LD & .003 & .002 & .003 & LD & .388 \\
\hline \multirow[t]{2}{*}{ Copper, in mg/L } & Dis & LD & .004 & .008 & .005 & .004 & LD & .278 \\
\hline & Col & LD & LD & LD & LD & .004 & LD & .278 \\
\hline \multirow[t]{2}{*}{ Iron, in mg/L } & Dis & LD & LD & LD & LD & .024 & LD & .007 \\
\hline & Col & .186 & .109 & .125 & .233 & .024 & LD & .007 \\
\hline \multirow[t]{2}{*}{ Manganese, in $\mathrm{mg} / \mathrm{L}$} & Dis & .021 & .035 & .636 & 2.42 & .038 & .038 & 13.1 \\
\hline & $\mathrm{Col}$ & LD & .003 & .005 & $\mathrm{LD}$ & .038 & .038 & 13.1 \\
\hline \multirow[t]{2}{*}{ Nickel, in mg/L } & Dis & LD & LD & LD & LD & LD & LD & .009 \\
\hline & $\mathrm{Col}$ & LD & LD & LD & LD & LD & LD & .009 \\
\hline \multirow[t]{2}{*}{ Lead, in mg/L } & Dis & LD & LD & .012 & .081 & .004 & LD & 1.30 \\
\hline & $\mathrm{Col}$ & .001 & .026 & .047 & .117 & .004 & LD & 1.30 \\
\hline \multirow[t]{2}{*}{ Strontium, in mg/L } & Dis & .159 & .152 & .137 & .395 & .114 & .113 & 1.24 \\
\hline & Col & LD & .005 & .007 & LD & .114 & .113 & 1.24 \\
\hline \multirow[t]{2}{*}{ Zinc, in mg/L } & Dis & .002 & .253 & 4.22 & 14.1 & .194 & .012 & 86.9 \\
\hline & Col & LD & .015 & .122 & .162 & .194 & .012 & 86.9 \\
\hline
\end{tabular}


The first effect on stream samples is seen by the change from group 1 to group 2a. This change occurred downstream from the Last Chance Mine (WW-2304) and occurred in stream samples collected from upstream of the Amethyst Mine to the sample collected upstream from the Nelson Tunnel, WW-4710. A second group of stream samples with slightly higher concentrations is classified as group $2 \mathrm{~b}$ and included the three samples collected downstream from the confluence of East and West Willow Creeks. The greatest shift in concentration among the stream samples occurred downstream from the inflow of the Nelson Tunnel (WW-NT). At that point, the samples shift to the higher concentrations measured in group 3 . Thus, the stream samples change systematically to the right on the biplot with increasing concentrations from group 1 in the recharge area, to group 2a near the Amethyst Mine, to group 3 downstream from the Nelson Tunnel. Then the shift is back to the left, to group $2 b$, downstream from the confluence with East Willow Creek. This shift is in the direction of the East Willow sample, EW-A.

\section{Load Profiles}

Transferring chemical data into a hydrologic context provides information that can be useful for remediation decisions and for quantifying the physical, chemical, and biological processes that affect metal transport and availability. This hydrologic context comes from detailed spatial profiles of load that are possible from combining the tracer-injection study with synoptic sampling for chemistry. As defined in the "Methods" section, load profiles provide the sampled instream load, which yields the data on net loading or attenuation for each stream segment. These data can be used to calculate the cumulative instream load, which gives the best estimate of the total loading for an element in a study reach. An evaluation of how well the sampled inflows account for the cumulative instream load comes from the cumulative inflow load. The cumulative instream load is calculated from totalrecoverable concentrations, but sampled instream load can be calculated by using the dissolved or colloidal concentrations. This permits an evaluation of instream chemical reactions.

A summary of load calculations for selected metals in West Willow Creek is listed in table 3. Values in table 3 come from the load profiles of each solute.
The five stream segments that have the greatest loading are indicated in each column. Concentrations of $\mathrm{Cu}$ and $\mathrm{Ni}$ were too low to be able to calculate load profiles, therefore, they are not included in table 3.

As an example of how the profiles are used, the load profile of $\mathrm{Al}$ (fig. 10) shows five different curves, as described in the "Methods" section. Cumulative instream load is the best estimate of the total quantity of a metal entering the stream along the study reach, which was $9.17 \mathrm{~kg} /$ day for total Al. Cumulative inflow load shows whether or not the sampled inflows account for that total instream load. For $\mathrm{Al}$, the cumulative inflow load was only 33 percent of the cumulative instream load. Subtracting the inflow load from the instream load gives the unsampled load, which was 67 percent for Al. The difference between the cumulative instream load and the total instream load, including both dissolved and colloidal load, is the amount of attenuation along the study reach. This was 27 percent of the cumulative instream load for Al. Only a small part of that attenuation was from the loss of load at WW-5189 because $\mathrm{Al}$ concentrations were low.

Cumulative instream loads varied considerably among these solutes (table 3). Because $\mathrm{SO}_{4}$ is a product of pyrite oxidation as well as the oxidation and dissolution of other metal-bearing sulfide minerals, it commonly has a much greater load than any of the metals. However, $\mathrm{SO}_{4}$ can be added to the stream through dissolution reactions of gypsum or anhydrite, which may be present as accessory minerals. Among the metals, $\mathrm{Zn}$ and Mn have substantially greater loads than the others. In fact, the cumulative instream load of $\mathrm{Zn}$ is one of the highest of all the watersheds in the Rocky Mountains where tracer-injection studies have been used to quantify loadings (Kimball and others, 1994; Kimball and others, 1999a; Kimball and others, 1999b; Cleasby and others, 2000; Kimball and others, 2001; Kimball and others, 2002). 
Table 3. Summary of load calculations, West Willow Creek, Colorado, September 2000

[Loads reported in kilograms per day, except for percent values; italicized bold numbers in parentheses indicate rank for the five greatest loads of each constituent]

\begin{tabular}{|c|c|c|c|c|c|c|c|c|c|}
\hline Segment ID & $\begin{array}{l}\text { Distance, } \\
\text { in meters }\end{array}$ & Aluminum & Cadmium & Iron & Manganese & Lead & Strontium & Zinc & Sulfate \\
\hline WW-430 (T-0) & 430 & (3) 0.527 & 0.015 & (3) 1.71 & 0.193 & 0.014 & (2) 1.27 & 0.022 & (4) 139 \\
\hline WW-634 & 634 & .056 & .003 & -.015 & -.018 & .015 & .065 & .016 & -.239 \\
\hline WW-846 & 846 & .067 & -.008 & .040 & -.002 & -.020 & -.140 & -.033 & .638 \\
\hline WW-1296 & 1,296 & .115 & .018 & -.244 & .168 & .045 & .110 & .009 & -1.04 \\
\hline WW-1729 & 1,729 & .000 & .000 & .000 & .000 & .000 & .000 & .000 & .000 \\
\hline WW-2054 & 2,054 & -.086 & -.011 & -.115 & -.023 & .073 & .041 & .056 & 4.02 \\
\hline WW-L & 2,304 & .059 & -.002 & -.015 & .071 & .054 & -.000 & .054 & 8.04 \\
\hline WW-2464 & 2,464 & .075 & -.003 & -.060 & .062 & -.016 & .104 & .007 & .259 \\
\hline WW-2627 & 2,627 & -.257 & -.001 & -.187 & .087 & -.150 & -.155 & .400 & 2.33 \\
\hline WW-K & 2,667 & .140 & .017 & .107 & -.228 & (5).203 & .112 & .143 & 1.24 \\
\hline WW-J & 2,829 & .000 & .000 & .000 & .000 & .000 & .000 & .000 & .000 \\
\hline WW-I & 3,021 & .098 & .023 & -.035 & .057 & .145 & -.030 & 1.42 & 17.2 \\
\hline WW-3186 & 3,186 & .067 & .008 & .004 & -.018 & .043 & .097 & .385 & 8.30 \\
\hline WW-3299 & 3,299 & -.018 & .000 & -.115 & .162 & -.072 & .027 & .196 & 10.2 \\
\hline WW-3489 & 3,489 & .087 & .004 & .075 & -.152 & .036 & -.002 & .117 & .540 \\
\hline WW-3600 & 3,600 & .114 & .006 & -.041 & -.037 & .031 & .100 & .145 & 1.10 \\
\hline WW-3728 & 3,728 & .127 & -.002 & .061 & .259 & -.002 & .001 & .032 & 1.48 \\
\hline WW-HH & 3,858 & -.126 & -.001 & -.141 & -.136 & -.083 & -.090 & -.090 & 2.83 \\
\hline WW-4081 & 4,081 & .001 & .029 & .120 & -.020 & .009 & .042 & .219 & 3.53 \\
\hline WW-H & 4,245 & .025 & -.023 & -.158 & -.041 & .071 & .101 & -.087 & 6.29 \\
\hline WW-4401 & 4,401 & (4). 443 & -.056 & -.161 & .062 & -.284 & -.084 & .152 & .093 \\
\hline WW-G & 4,577 & -.486 & .000 & -.017 & .204 & -.071 & .110 & .073 & 6.73 \\
\hline WW-4710 & 4,710 & .099 & .069 & .169 & -.197 & (3). 315 & .201 & .624 & 1.61 \\
\hline WW-F & 4,766 & (2).934 & (1).475 & (2)2.65 & (1) 28.4 & (1) 2.26 & (1)3.04 & (1)158 & (1) 1,540 \\
\hline WW-4866 & 4,866 & -.134 & -.195 & -.221 & (2) 4.93 & .062 & (5).448 & (4) 19.8 & (2)174 \\
\hline WW-4980 & 4,980 & (5).374 & (5).137 & -.184 & (3) 2.87 & .166 & .160 & (3) 21.2 & (5) 98.4 \\
\hline WW-D & 5,063 & .134 & (3).297 & (5).312 & -.583 & .133 & .125 & -1.10 & 17.0 \\
\hline WW-5189 & 5,189 & -.646 & -.407 & -1.04 & -6.24 & -.846 & -1.18 & -39.7 & -417 \\
\hline WW-B & 5,282 & .101 & (4). 214 & .133 & -3.26 & (4). 176 & .056 & -.411 & 1.24 \\
\hline WW-5383 & 5,383 & .125 & .020 & .069 & .074 & .044 & -.064 & -.100 & 11.2 \\
\hline WW-A & 5,540 & -.288 & -.076 & -.211 & (5) 1.76 & -.160 & .279 & 1.3 & 25.0 \\
\hline W-A & 5,716 & (1)5.22 & (2).387 & (1)3.90 & 3.44 & (2).913 & (3) 2.00 & (2) 36.2 & (3)433 \\
\hline EW-5892 & 6,450 & -.461 & -.010 & -.545 & -.633 & -.506 & -.712 & 3.91 & 23.1 \\
\hline EW-6044 & 6,602 & .177 & .118 & (4).319 & (4) 2.64 & .113 & (4).663 & (5) 15.5 & 4.91 \\
\hline \multicolumn{2}{|c|}{ Cumulative instream load } & 9.17 & 1.84 & 9.66 & 45.5 & 4.92 & 9.16 & 269 & 2,540 \\
\hline \multicolumn{2}{|c|}{ Cumulative inflow load } & 3.07 & .890 & 2.68 & 37.5 & 3.29 & 6.55 & 215 & 2,200 \\
\hline \multicolumn{2}{|c|}{ Percent inflow load } & 33 & 48 & 28 & 82 & 67 & 72 & 80 & 87 \\
\hline \multicolumn{2}{|l|}{ Attenuation } & 2.5 & .790 & 3.51 & 11.6 & 2.21 & 2.47 & 41.6 & 418 \\
\hline \multicolumn{2}{|c|}{ Percent attenuation } & 27 & 43 & 36 & 25 & 45 & 27 & 15 & 16 \\
\hline \multicolumn{2}{|c|}{ Unsampled inflow } & 6.10 & .950 & 6.98 & 8.00 & 1.63 & 2.61 & 54.0 & 340 \\
\hline \multicolumn{2}{|c|}{ Percent unsampled inflow } & 67 & 52 & 72 & 18 & 33 & 28 & 20 & 13 \\
\hline
\end{tabular}



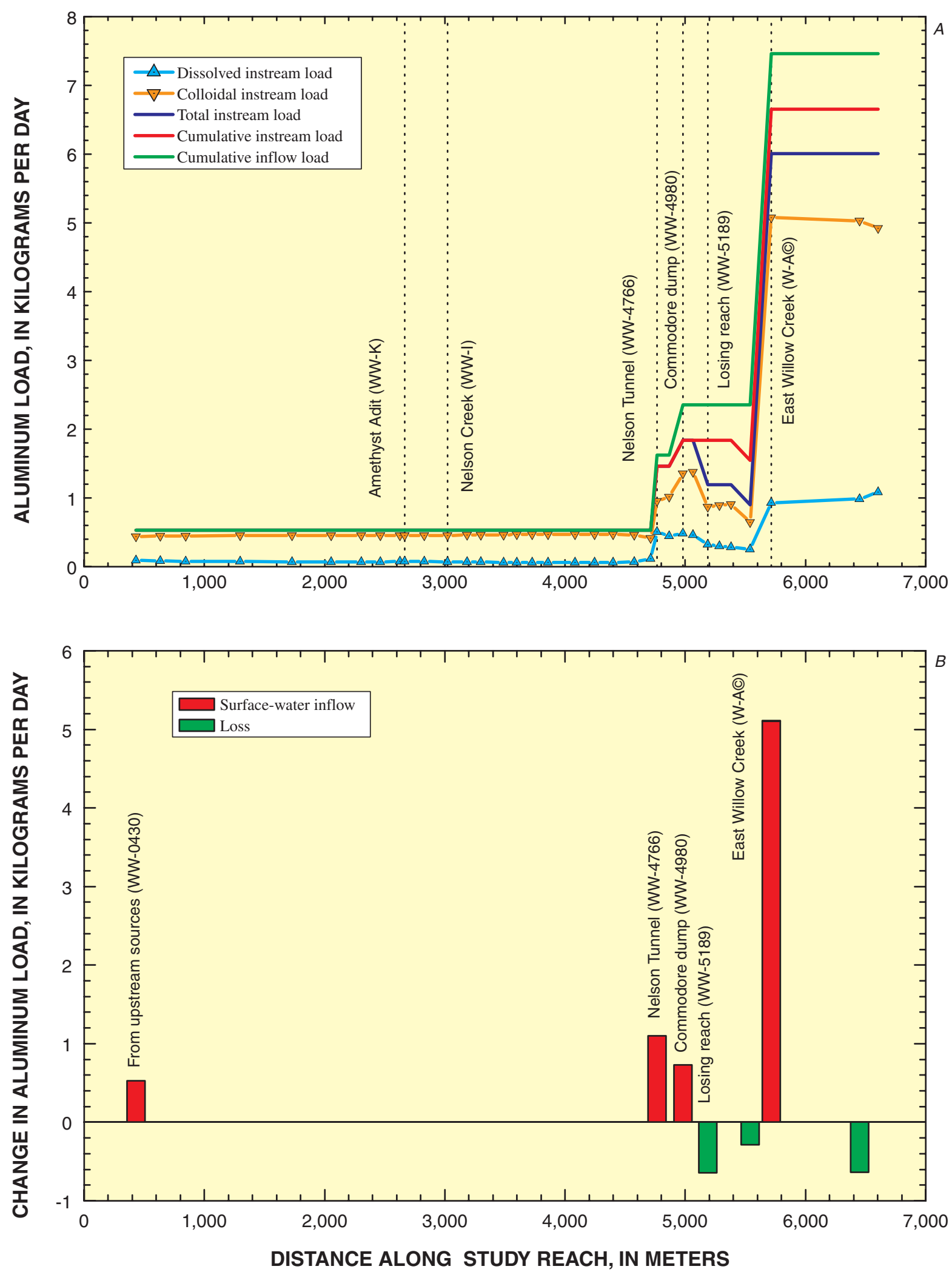

Figure 10. (A) Variation of aluminum load with distance and (B) changes in aluminum load for individual stream segments, West Willow Creek, Colorado, September 2000. 
Differences in the amount of unsampled inflow were noted among the solutes. The unsampled inflows of $\mathrm{Mn}, \mathrm{Sr}, \mathrm{Zn}$, and $\mathrm{SO}_{4}$ were much smaller than those of $\mathrm{Al}$ and $\mathrm{Fe}$ (table 3). This grouping is consistent with the geochemical behavior of these solutes. Aluminum and $\mathrm{Fe}$ are among the most reactive constituents and $\mathrm{Mn}, \mathrm{Zn}$, and $\mathrm{SO}_{4}$ are less reactive. Thus, $\mathrm{Mn}, \mathrm{Zn}$, and $\mathrm{SO}_{4}$ were not lost from the aqueous phase during transport to the stream from metal sources away from the stream. For this same reason, $\mathrm{Zn}$ and $\mathrm{SO}_{4}$ had the least amount of attenuation in the stream. Attenuation of Mn was measurable, but much less than attenuation of $\mathrm{Al}, \mathrm{Cd}, \mathrm{Fe}$, and $\mathrm{Pb}$. Given these general characteristics of loading, the loading profiles mostly fall into two groups that include $\mathrm{Mn}, \mathrm{Zn}$, and $\mathrm{SO}_{4}$ in one group and $\mathrm{Al}, \mathrm{Fe}$, and $\mathrm{Cd}$ in another. Strontium and $\mathrm{Pb}$ had characteristics of both groups.

Loading profiles for Mn (fig. 11), $\mathrm{Zn}$ (fig. 12), $\mathrm{Sr}$ (fig. 13), and $\mathrm{SO}_{4}$ (fig. 14) are dominated by loading from the Nelson Tunnel (accounted for at stream site WW-F), and the substantial loading in the two stream segments just downstream from the Nelson Tunnel (WW-4866 and WW-4930). The inflow at WW-4866 was "unsampled" inflow for $\mathrm{Mn}, \mathrm{Zn}$, and $\mathrm{SO}_{4}$ (figs. 11B, 12B, and 14B). White Al precipitate in a sampled inflow in segment WW-4930 coated logs and rocks before the inflow entered the stream. Both $\mathrm{Sr}$ and $\mathrm{SO}_{4}$ have sources from non-ore minerals, and their loading profiles indicate sources upstream from the beginning of the study reach.

Although substantial loads of $\mathrm{Al}$ (fig. 10) and $\mathrm{Fe}$ (fig. 15) were added to West Willow Creek by the Nelson Tunnel discharge, East Willow Creek also had substantially greater loads of these solutes. East Willow Creek also was an important source for Cd (fig. 16) and $\mathrm{Pb}$ (fig. 17). Much of the cumulative instream load for Fe came from unsampled inflow, similar to the load for Al. If the loads come from dispersed, subsurface inflow, the $\mathrm{Al}$ and $\mathrm{Fe}$ can enter the stream before being removed if they have remained soluble in the subsurface. Once in the stream, however, they have a tendency to precipitate and form colloidal particles. This is evident by the relatively large percentage of Al and Fe that were removed by attenuation. Slightly greater percentages of $\mathrm{Cd}$ and $\mathrm{Pb}$ were removed, and this was most likely through sorption to the Fe colloidal material that was formed.

\section{Principal Locations of Mass Loading}

Net instream load for each stream segment allows for a ranking of segments according to their contribution of mass to the stream. Mass of a constituent, not its concentration in an inflow, determines the real effects on the stream (Kimball and others, 2002). The change in mass for any stream segment can be divided by the cumulative instream load to give a percentage of the total load contributed by each segment. However, this percentage may be affected by a net loss of solute for a stream reach. For example, stream segments with sampled inflows may have a positive inflow load and yet may have a negative instream load because chemical reactions are fast enough to remove the solutes before transport to the downstream end of the stream segment.

Two clear patterns emerge from these loadings (table 3). First, the Nelson Tunnel (accounted for at WW-F) contributed the greatest loads of $\mathrm{Cd}, \mathrm{Mn}, \mathrm{Pb}$, $\mathrm{Sr}, \mathrm{Zn}$, and $\mathrm{SO}_{4}$. Generally, this was greater than 50 percent of the load along the study reach. For some of these solutes, the Nelson Tunnel contributed about 10 times the load contributed by any other stream segment. Not only did the Nelson Tunnel contribute the majority of load for most solutes, but there were also substantial loads contributed for $\mathrm{Cd}, \mathrm{Mn}, \mathrm{Pb}, \mathrm{Zn}$, and $\mathrm{SO}_{4}$ in the two segments downstream from the Nelson Tunnel (WW-4866 and WW-4980). These loads could result from leakage of Nelson Tunnel discharge into the large waste-rock pile at the Commodore Mine and then discharge of this leakage to the stream.

The second pattern is that $\mathrm{Al}$ and $\mathrm{Fe}$, and to some extent $\mathrm{Pb}$ and $\mathrm{Sr}$, are substantially contributed in the stream segment that includes East Willow Creek (W$\left.\mathrm{A}^{\prime}\right)$. For each of these solutes, except $\mathrm{Sr}$, this contribution was mostly transformed to the colloidal phase within the stream segment W-A'. The majority of this load, however, was unsampled inflow. It is not clear if this unsampled inflow came from the discharge of East Willow Creek, or perhaps upwelling of water from the drainage of East Willow, West Willow, or both. 

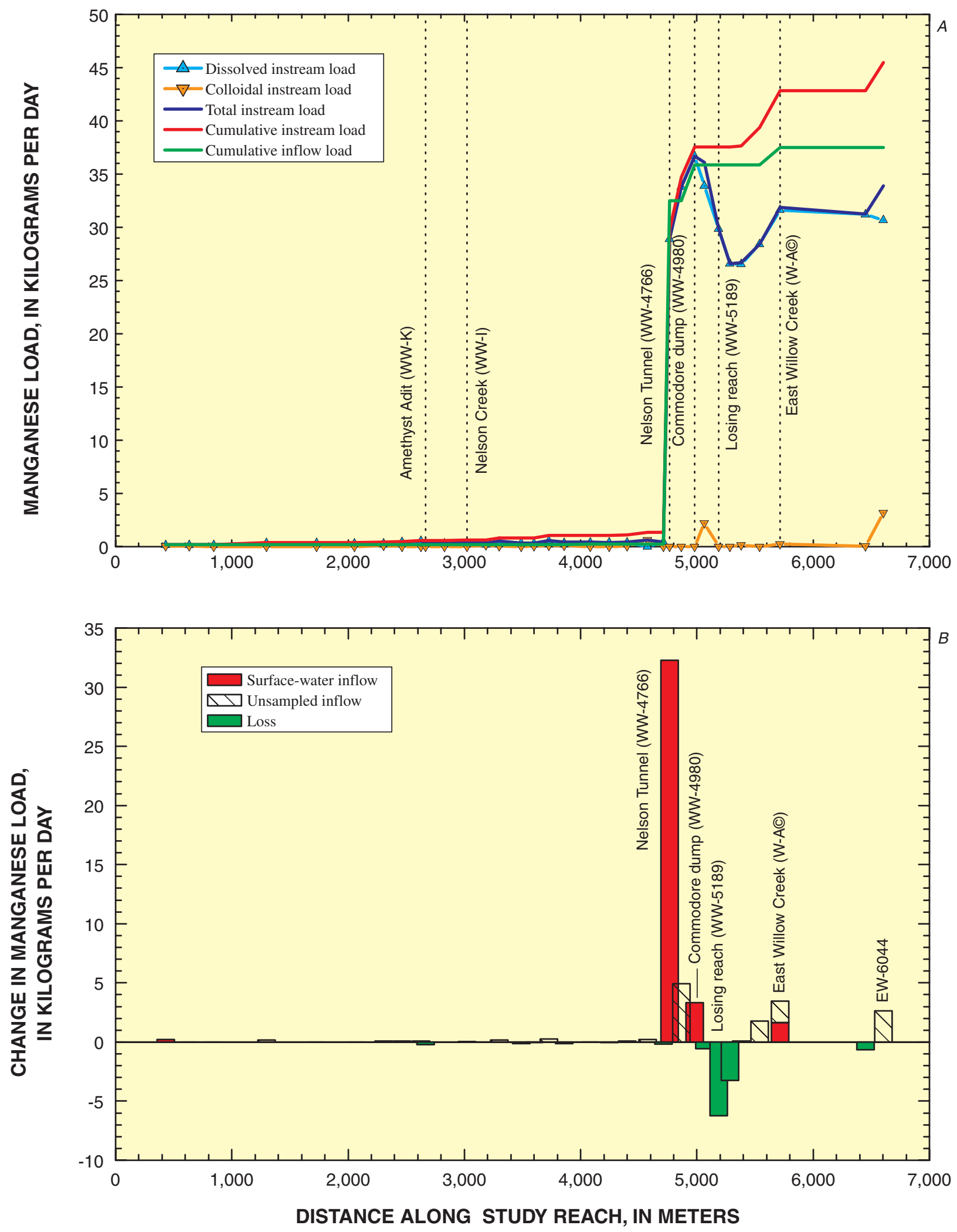

Figure 11. (A) Variation of manganese load with distance and (B) changes in manganese load for individual stream segments, West Willow Creek, Colorado, September 2000. 

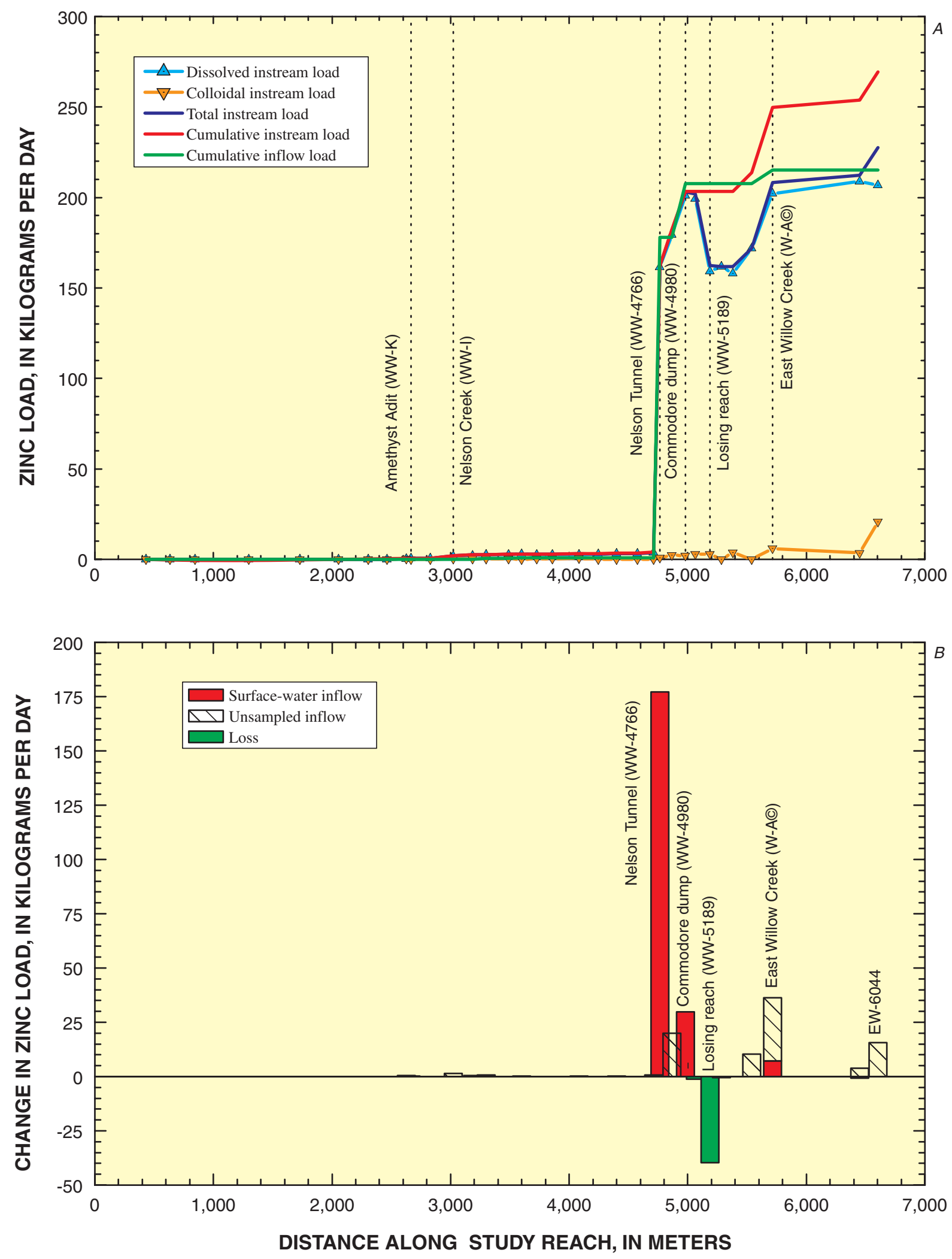

Figure 12. (A) Variation of zinc load with distance and (B) changes in zinc load for individual stream segments, West Willow Creek, Colorado, September 2000. 

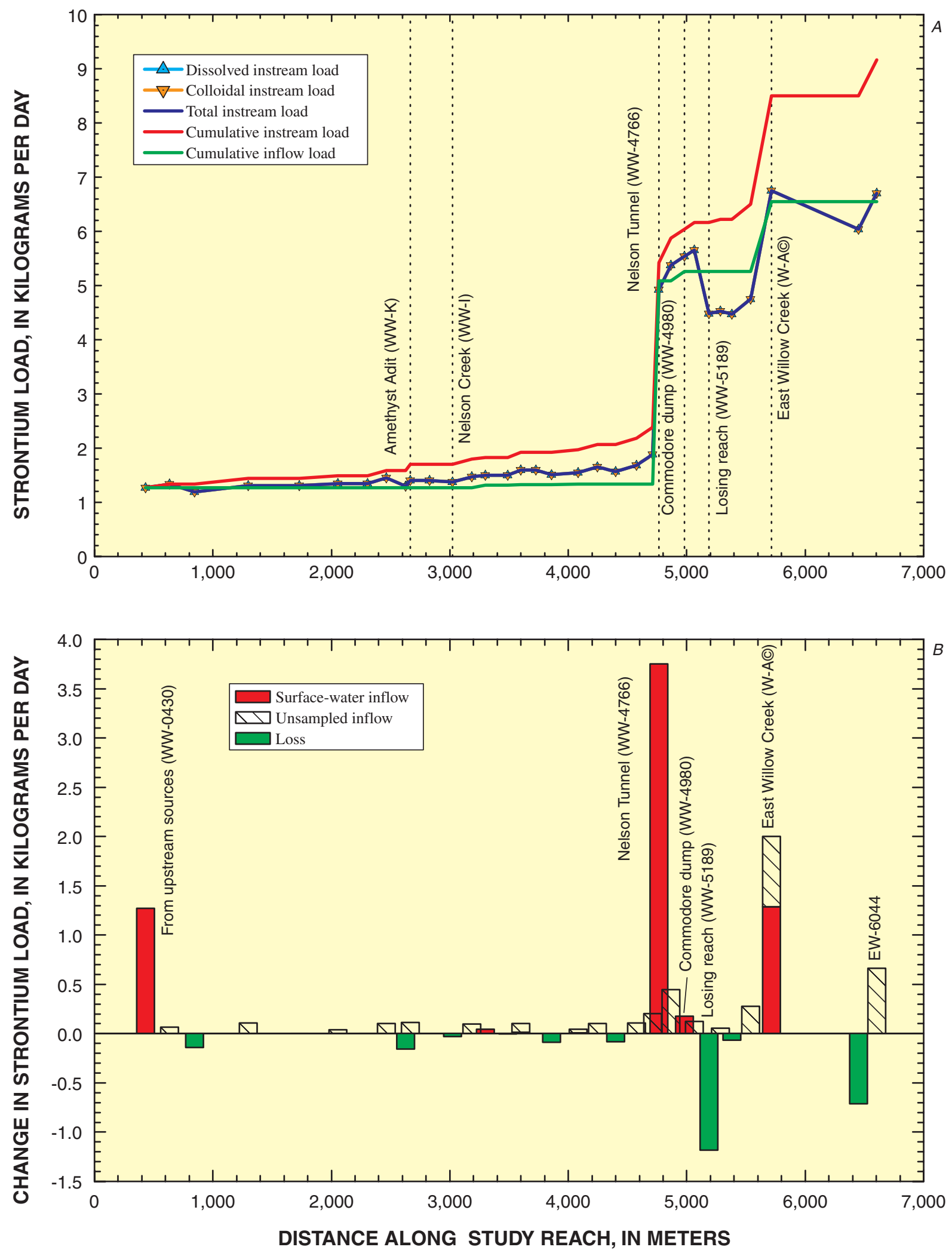

Figure 13. (A) Variation of strontium load with distance and (B) changes in strontium load for individual stream segments, West Willow Creek, Colorado, September 2000. 

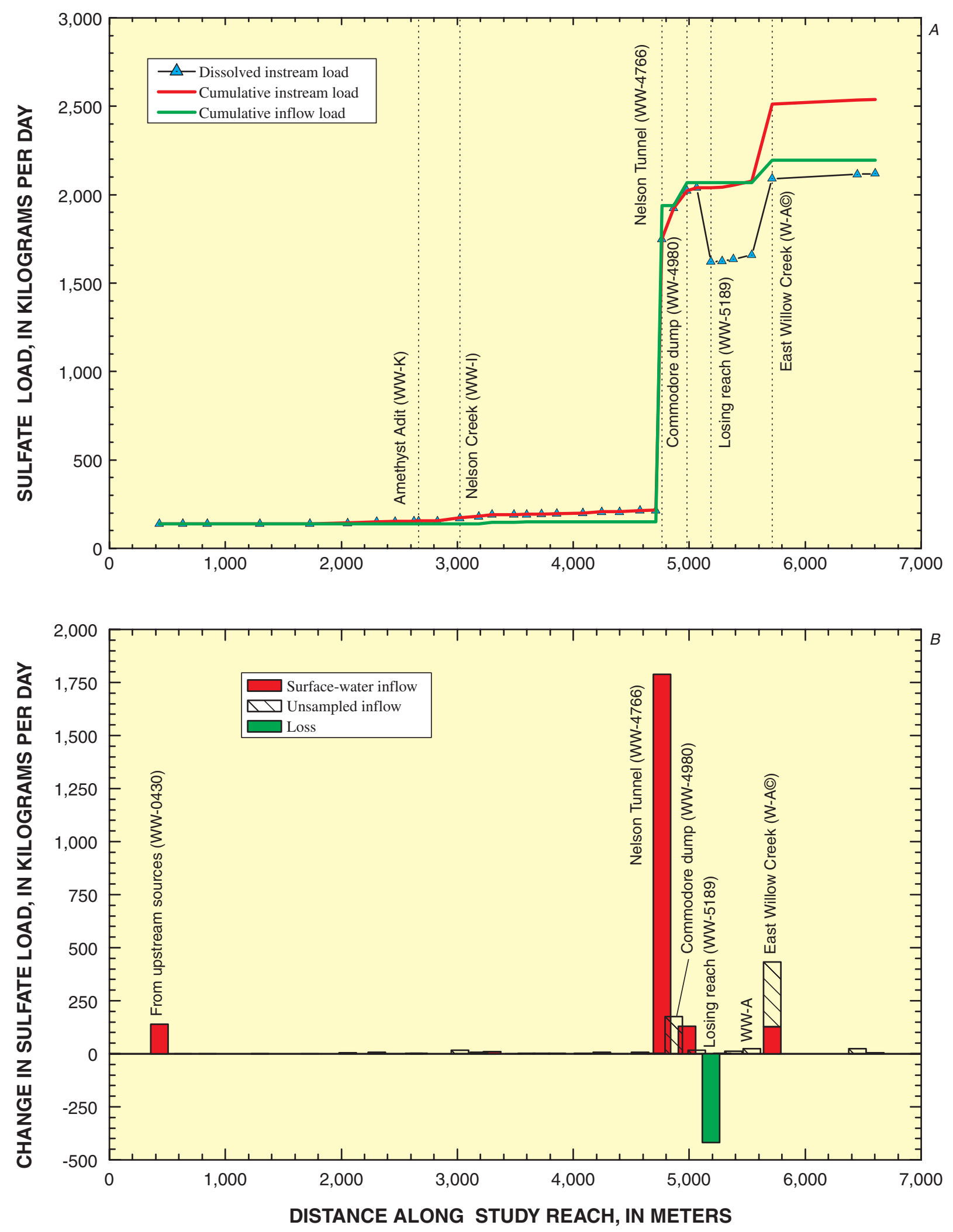

Figure 14. (A) Variation of sulfate load with distance and (B) changes in sulfate load for individual stream segments, West Willow Creek, Colorado, September 2000. 

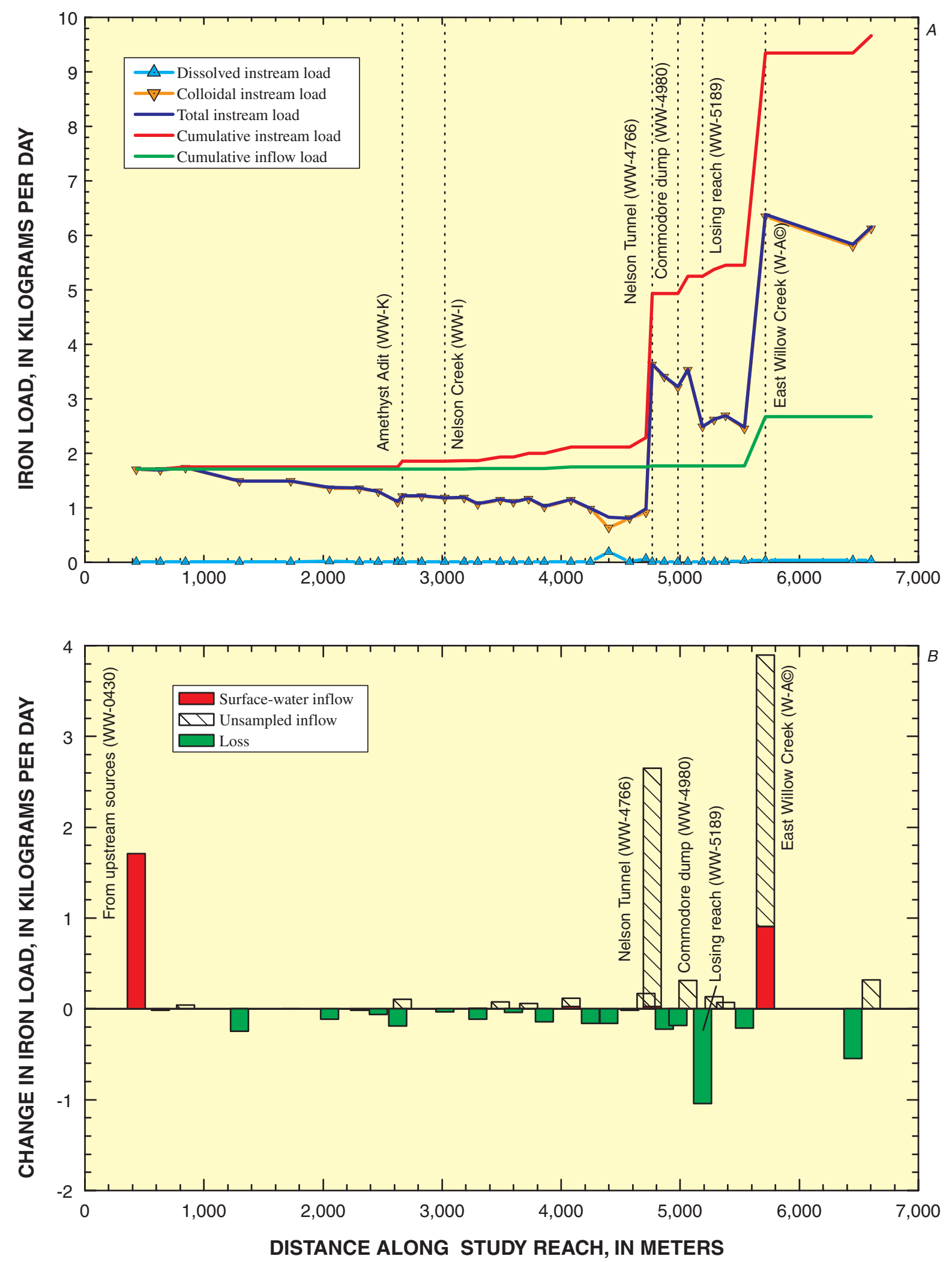

Figure 15. (A) Variation of iron load with distance and (B) changes in iron load for individual stream segments, West Willow Creek, Colorado, September 2000. 

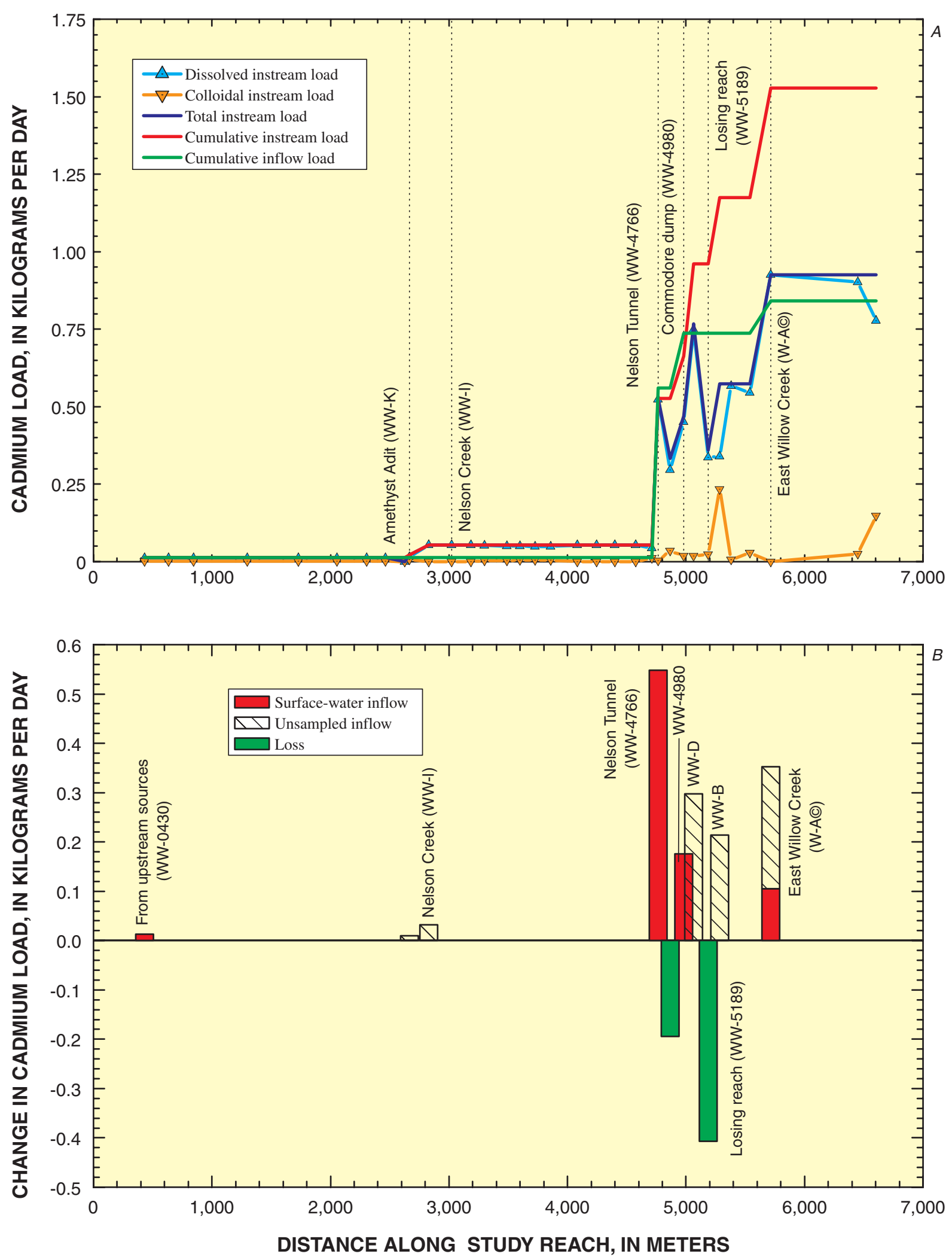

Figure 16. (A) Variation of cadmium load with distance and (B) changes in cadmium load for individual stream segments, West Willow Creek, Colorado, September 2000. 

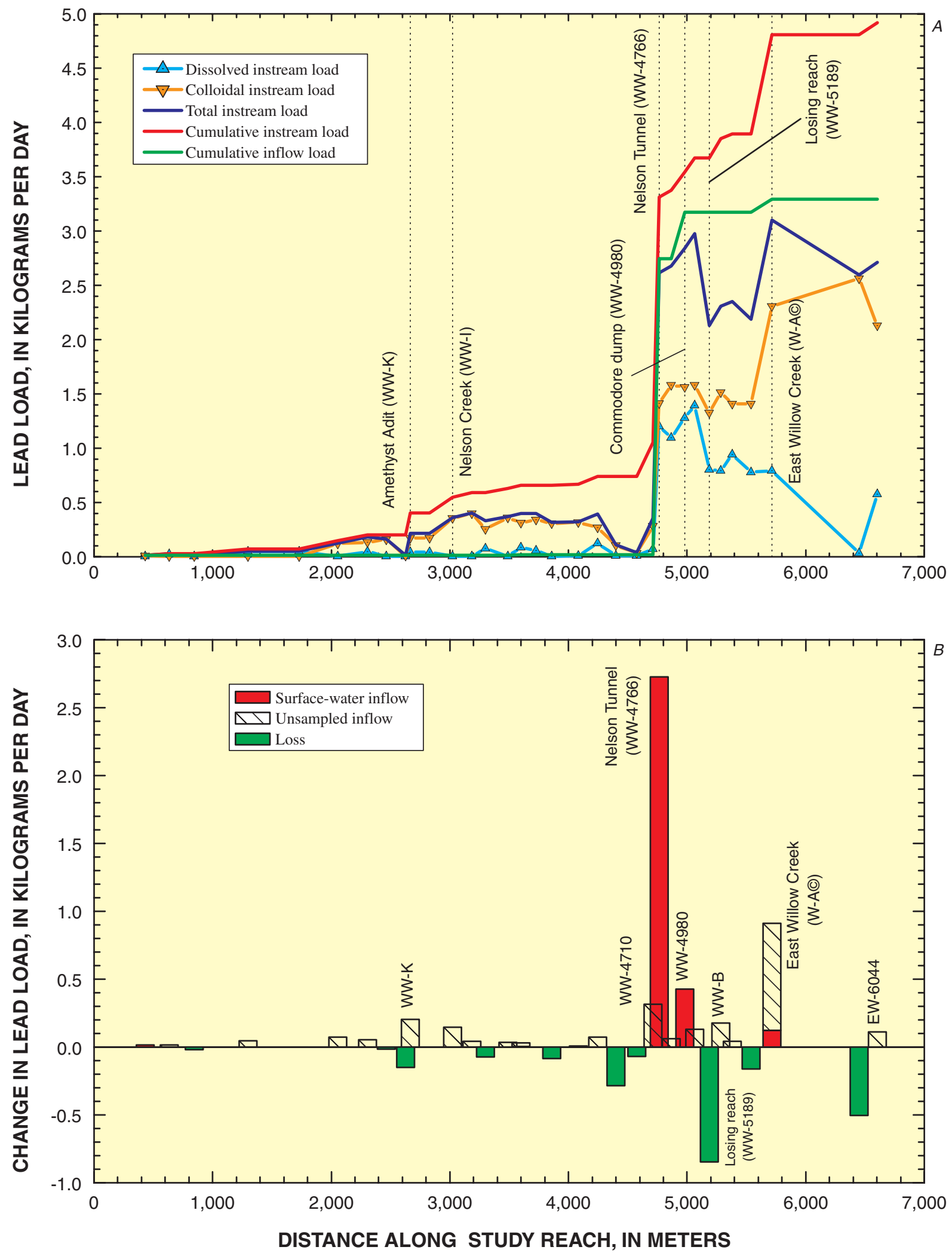

Figure 17. (A) Variation of lead load with distance and (B) changes in lead load for individual stream segments, West Willow Creek, Colorado, September 2000. 


\section{Unsampled Inflow}

There were three locations with considerable amounts of unsampled inflow (figs. 10-17). The first was segment WW-4866, downstream from the Nelson Tunnel. Unsampled inflow of $\mathrm{Mn}, \mathrm{Sr}, \mathrm{Zn}$, and $\mathrm{SO}_{4}$ occurred in this segment. As noted above, this unsampled inflow was likely from infiltration of Nelson Tunnel discharge and subsequent discharge downstream. It also could be from an alternative pathway from the mine workings to the stream. The second location was at the confluence of East and West Willow Creeks, segment W-A'. The unsampled inflow was greatest for $\mathrm{Al}, \mathrm{Fe}$, and $\mathrm{Pb}$ in that segment. Loading from subsurface water in this segment could be from East or West Willow, or both. Data from these tracer studies cannot distinguish between the two sources. The third location of unsampled inflow was in the last segment of the study reach, EW-6044. This loading could represent subsurface inflow from Windy Gulch and was most important for $\mathrm{Mn}, \mathrm{Sr}$, and $\mathrm{Zn}$. It is not possible to distinguish the inflow between Windy Gulch and other possible sources because it could also be from mine wastes within the Willow Creek drainage. Most of the alluvial material near the end of the canyon has been reworked and could contain source material.

\section{Attenuation of Load}

Attenuation of metal loads ranged from a high of 45 percent for $\mathrm{Pb}$, to 15 percent for $\mathrm{Zn}$ (table 3). In an

$\mathrm{Fe}$-rich system where there is abundant formation of $\mathrm{Fe}$ colloids, it is common to see substantial metal attenuation (Kimball and others, 1994). In West Willow Creek, $\mathrm{pH}$ was greater than 7.0, even downstream from metal-rich inflows. At this $\mathrm{pH}$, it would be reasonable to expect substantial sorption of metals to the iron hydroxide colloids. Yet, relatively little attenuation occurred. After the inflow of the Nelson Tunnel discharge and the two subsequent stream segments that had substantial unsampled inflow, some attenuation of $\mathrm{Cd}, \mathrm{Fe}, \mathrm{Mn}$, and Zn occurred in segments WW-5189, WW-B, WW-5383, and WW-A. Subsequently, downstream from the inflow of East Willow Creek, in segments W-A' and EW-5892, attenuation of Fe, Mn, $\mathrm{Pb}$, and $\mathrm{Sr}$ was measurable. No attenuation of $\mathrm{SO}_{4}$ occurred, however, which is consistent with the $\mathrm{pH}$ value greater than 7.5 in these stream segments.

\section{East Willow Creek}

Load profiles from West Willow Creek indicated increases in the load of some constituents in the segment that included the inflow of East Willow Creek. To determine where these loads originated in East Willow Creek, a tracer injection was used to identify possible sources in that drainage.

The East Willow Creek tracer injection covered a 6,044-m section of the Willow Creek watershed, starting upstream from the Outlet Mine and continuing past the confluence with West Willow Creek to the gaging station just upstream from the town of Creede (fig. 2). There were no major inflows to the stream along the study reach, but discharge did increase from some discharge of dispersed, subsurface flow and mine-drainage tunnels. The Solomon Mine was the principal mine drainage entering the stream in the study reach.

The 6,044-m study reach was divided into 21 segments by the stream sampling sites (fig. 2). Stream segments bracketed 12 inflow samples, but there likely were areas of subsurface inflow also bracketed by stream samples. Segment designations, downstream distance, and information about the sampling sites are listed in table 4. Only 9 stream segments contained sampled inflows; the other 12 segments had no sampled inflow.

\section{Discharge}

A $\mathrm{NaBr}$ tracer with a $\mathrm{Br}$ concentration of $151,250 \mathrm{mg} / \mathrm{L}$ was injected at a rate of $0.004 \mathrm{~L} / \mathrm{s}$. The systematic decrease of $\mathrm{Br}$ concentration downstream from the injection site allowed the calculation of discharge at each of the stream sampling sites (fig. 18). The increase in discharge along the study reach was from $341 \mathrm{~L} / \mathrm{s}$ at the injection site to $619 \mathrm{~L} / \mathrm{s}$ at the downstream gage. West Willow Creek accounted for $199 \mathrm{~L} / \mathrm{s}$ of the increase, or 72 percent. Discharge increased by $79 \mathrm{~L} / \mathrm{s}$ upstream from the confluence with West Willow Creek, and 39 percent of that increase was from segments that had no sampled inflows. 
Table 4. Synoptic sampling sites, East Willow Creek, Colorado, August 2000

[Distance, in meters along the study reach; dashed line indicates samples that were collected upstream from the confluence with West Willow Creek]

\begin{tabular}{|c|c|c|c|c|c|}
\hline $\begin{array}{c}\text { Site } \\
\text { designation }\end{array}$ & Source & $\begin{array}{l}\text { Distance, } \\
\text { in meters }\end{array}$ & Site description & $\begin{array}{c}\mathrm{pH}, \\
\text { in standard } \\
\text { units }\end{array}$ & $\begin{array}{l}\text { Discharge, } \\
\text { (in liters per } \\
\text { second }\end{array}$ \\
\hline EW-T0 & Stream & 947 & Upstream from injection site & 7.90 & 341 \\
\hline TRN & Inflow & 1,079 & Left bank drainage through culvert & 7.78 & .10 \\
\hline TRS & Inflow & 1,129 & Spring discharging from hill & 7.57 & .10 \\
\hline EW-K & Stream & 1,157 & East Willow Creek upstream from Outlet Mine & 7.91 & 341 \\
\hline EW-J & Stream & 1,447 & T1-East Willow Creek downstream from Outlet Mine & 7.90 & 348 \\
\hline EW-1807 & Stream & 1,807 & Along road to check for ground-water inflow & 7.92 & 350 \\
\hline EW-2175 & Stream & 2,175 & In canyon to check for ground-water inflow & 8.03 & 350 \\
\hline EW-I & Stream & 2,405 & Upstream from Solomon and Ridge Mines & 7.95 & 353 \\
\hline $\mathrm{PC}$ & Inflow & 2,695 & Pipe on left bank & 7.18 & 4.4 \\
\hline EW-H & Stream & 2,735 & Upstream from Solomon wetland & 7.91 & 358 \\
\hline SMA & Inflow & 2,790 & Solomon adit & 4.71 & .10 \\
\hline EW-2830 & Inflow & 2,811 & Spring discharge from Solomon Tunnel & 7.02 & 2.25 \\
\hline EW-2825 & Inflow & 2,825 & Drainage from Solomon ponds along road & 5.68 & 2.25 \\
\hline EW-2995 & Stream & 2,995 & $\mathrm{~T} 2$ - Stream downstream from Solomon ponds & 7.95 & 363 \\
\hline EW-G & Stream & 3,135 & Downstream from Solomon tailings & 8.01 & 367 \\
\hline EW-3525 & Stream & 3,525 & Upstream from spring on right bank at base of talus & 7.79 & 373 \\
\hline EW-3533 & Inflow & 3,533 & Spring from talus slope & 7.33 & 6.23 \\
\hline EW-E & Stream & 3,602 & East Willow Creek as valley gets constricted & 7.90 & 380 \\
\hline EW-D & Stream & 3,970 & East Willow Creek upstream from old diversions & 7.93 & 385 \\
\hline SWI & Inflow & 4,015 & Discharge at concrete diversion structure & 7.33 & 5.74 \\
\hline EW-4107 & Stream & 4,107 & Upstream end of culvert & 7.62 & 391 \\
\hline EW-4121 & Inflow & 4,121 & Small spring downstream from culvert & 7.33 & 7.39 \\
\hline EW-C & Stream & 4,157 & East Willow Creek upstream from Mammoth adit & 7.73 & 398 \\
\hline MA & Inflow & 4,183 & Pipe upstream hill discharging Mammoth adit flow & 7.66 & 17.3 \\
\hline EW-B & Stream & 4,613 & East Willow Creek upstream from North Creede site & 7.62 & 416 \\
\hline EW-A & Stream & 4,968 & T3-East Willow Creek near mouth & 7.67 & 419 \\
\hline$\overline{\mathrm{W}} \overline{\mathrm{W}}-\mathrm{A}$ & Inflow & $5, \overline{056}$ & $\overline{\text { West Willow Creek near mouth }} \overline{-}----$ & $7 . \overline{23}$ & $19 \overline{9}$ \\
\hline W-A & 'Stream & 5,158 & Willow Creek downstream from confluence & 7.45 & 618 \\
\hline EW-5292 & Stream & 5,292 & Willow Creek in reaction zone & 7.34 & 618 \\
\hline EW-5492 & Stream & 5,492 & Willow Creek upstream from braids and dam & 7.47 & 618 \\
\hline EW-5892 & Stream & 5,892 & Willow Creek upstream from pond near Windy Gulch & 6.79 & 618 \\
\hline EW-5944 & Inflow & 5,944 & Drainage from right bank pond near Windy Gulch & 7.06 & 1.07 \\
\hline EW-6044 & Stream & 6,044 & Willow Creek at Army Corps of Engineer gage & 7.12 & 619 \\
\hline
\end{tabular}




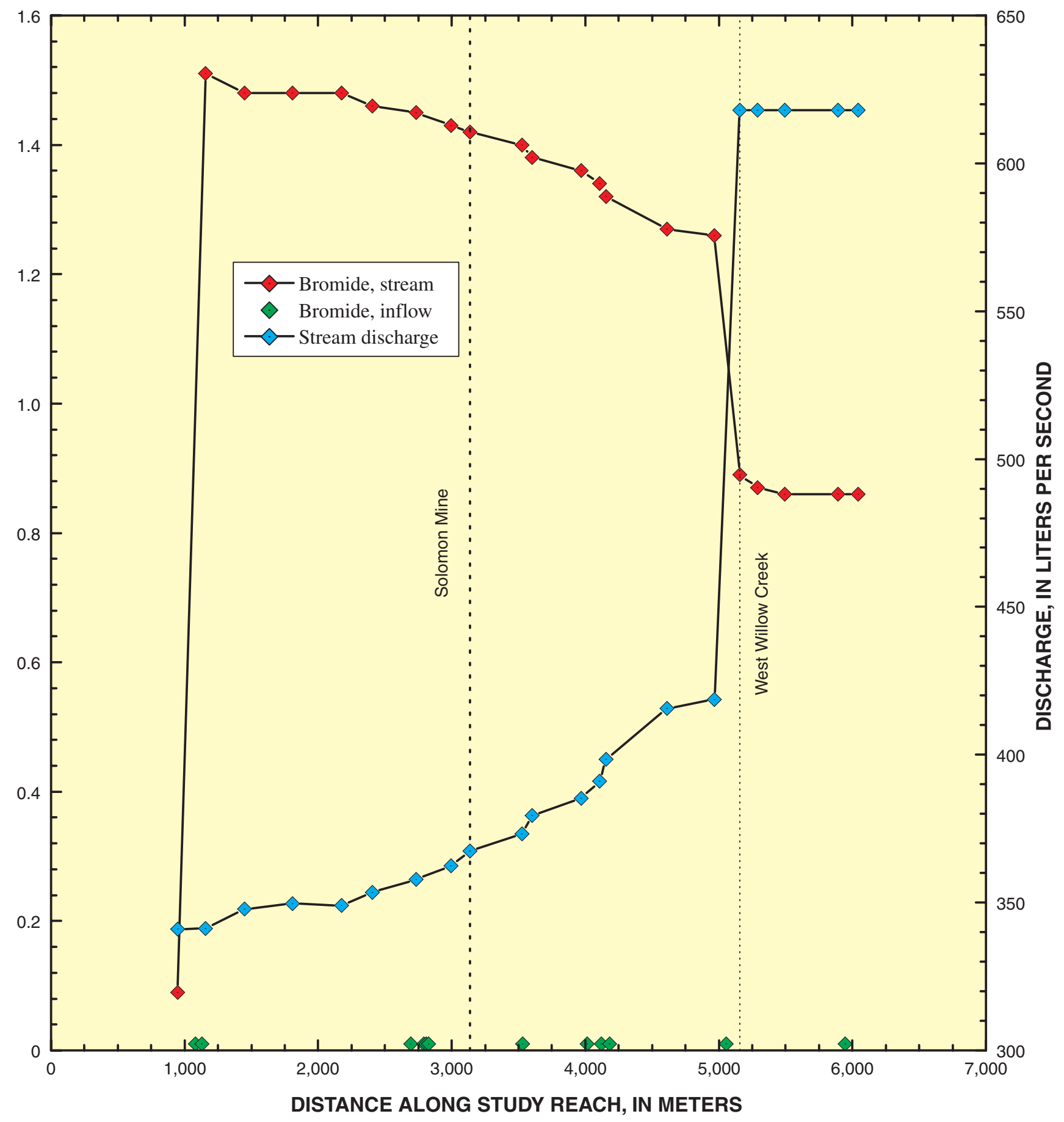

Figure 18. Variation of bromide concentration and calculated discharge, East Willow Creek, Colorado, August 2000. 


\section{Chemical Characterization of Synoptic Samples}

Analysis of synoptic samples collected along East Willow Creek indicates that the $\mathrm{pH}$ along the study reach to the confluence with West Willow Creek was near 8.0 (fig. 19A) and that the principal ions were $\mathrm{Ca}, \mathrm{Na}$ (not shown in figure), and $\mathrm{HCO}_{3}$ (fig. 19B). These major ions result mostly from weathering of non-ore minerals. In these upper reaches, the $\mathrm{SO}_{4}$ concentration of East Willow Creek is very low, indicating little effect from sulfide minerals. Downstream from the confluence with West Willow Creek, $\mathrm{pH}$ was less than 7.5 and the dominant ions were $\mathrm{Ca}$ and $\mathrm{SO}_{4}$. The sample at $\mathrm{W}-\mathrm{A}^{\prime}$ represents the mixing of East and West Willow Creeks.

Metal concentrations were high in some of the synoptic samples, but considerably lower than in West Willow Creek (fig. 20). Concentrations of dissolved Zn were the highest among the metals, with a maximum concentration of $4.1 \mathrm{mg} / \mathrm{L}$, and a median of $0.11 \mathrm{mg} / \mathrm{L}$. Colloidal concentrations of $\mathrm{Al}, \mathrm{Fe}$, and $\mathrm{Pb}$ were greater than the dissolved concentrations. Colloidal $\mathrm{Zn}$ concentration was not higher than dissolved $\mathrm{Zn}$ concentration, but was greater than detection in many of the stream samples. Concentrations of dissolved $\mathrm{Cu}$ were greater than those of colloidal $\mathrm{Cu}$; only a few samples indicated measurable colloidal $\mathrm{Cu}$.

Although metal concentrations were high in the sample from the Solomon Mine adit, no substantial change in the stream concentrations along East Willow Creek occurred downstream from the adit. Concentrations of $\mathrm{Zn}$ increased downstream from the area of the Solomon Tunnel, but this increase was small in comparison to the increase downstream from the confluence for West Willow Creek (fig. 21).

Concentrations of Mn were similar to those of Zn. Although Mn concentrations were high in samples collected at the Solomon Mine adit (SMA), instream concentrations did not increase greatly until the confluence with West Willow Creek. In contrast to this, concentrations of $\mathrm{Al}$ and $\mathrm{Fe}$ were low (fig. 22).

Concentrations of $\mathrm{Fe}$ and $\mathrm{Al}$ also were high in samples collected from the Solomon Mine adit, but these concentrations did not affect the stream concentrations. This could be from the effects of the constructed wetland, or because there is little hydrologic input from the adit to the stream.

These trends in composition are summarized by the groups of inflows and stream samples in a biplot of PCA results (fig. 23). Vectors for the constituents fall into two groups that are distinguished by those constituents that increase from the inflow of West Willow Creek (Ca, Mg, $\mathrm{SO}_{4}, \mathrm{Cd}, \mathrm{Sr}, \mathrm{pH}, \mathrm{Zn}, \mathrm{Na}, \mathrm{Pb}$, and $\mathrm{Cl}$ ), and those that vary to some degree in East Willow Creek ( $\mathrm{Fe}, \mathrm{Al}$, and $\mathrm{Cu}$ ). Within this framework, there are only two groups of stream samples. Group 1 includes all the samples in East Willow Creek upstream from West Willow Creek, and the inflows TRN and TRS, which had a chemistry similar to that of the stream samples. These samples vary somewhat in their $\mathrm{Fe}$ and $\mathrm{Al}$ concentrations, and there is some variation in $\mathrm{Zn}$, but overall there is not a great amount of variation along that part of East Willow Creek. Group 2 includes those stream samples that are downstream from the confluence, and this group is shifted to the right on the biplot, indicating the increase in all those constituents that are dominant in West Willow Creek. The shift is toward the West Willow sample, WW-A.

The highest concentrations of metals, including $\mathrm{Al}, \mathrm{Fe}$, and $\mathrm{Cu}$, were measured in the sample collected from the Solomon Mine adit (SMA, group 4). EW2825 (group 5) originated from the same source but had lower metal concentrations because the adit water had passed through constructed wetlands before the sample was collected. EW-2830 (group 2) originated from the Solomon Mine but was collected from a spring that issued near the stream, downstream from the Solomon adit and the constructed wetlands. It was not clear if that water drained from the adit or from the wetlands, but the sample had lower concentrations of metals than did sample EW-2825. Despite high concentrations of metals, these inflows had little effect on the stream chemistry. There was only a slight shift toward SMA among stream samples of group 1; group 1 samples that plot to the right generally were collected downstream from the Solomon Mine area. This mostly reflects the increase in $\mathrm{Zn}$ concentration, as mentioned above. A lack of the shift indicates that the Solomon Mine and the associated inflows had little influence on the stream chemistry. The only major shift in the stream chemistry came downstream from the confluence with West Willow Creek (group 2). The sample from Windy Gulch, EW-5944, was distinguished by low concentrations of $\mathrm{Al}, \mathrm{Fe}$, and $\mathrm{Cu}$, but relatively high concentrations of other metals. 

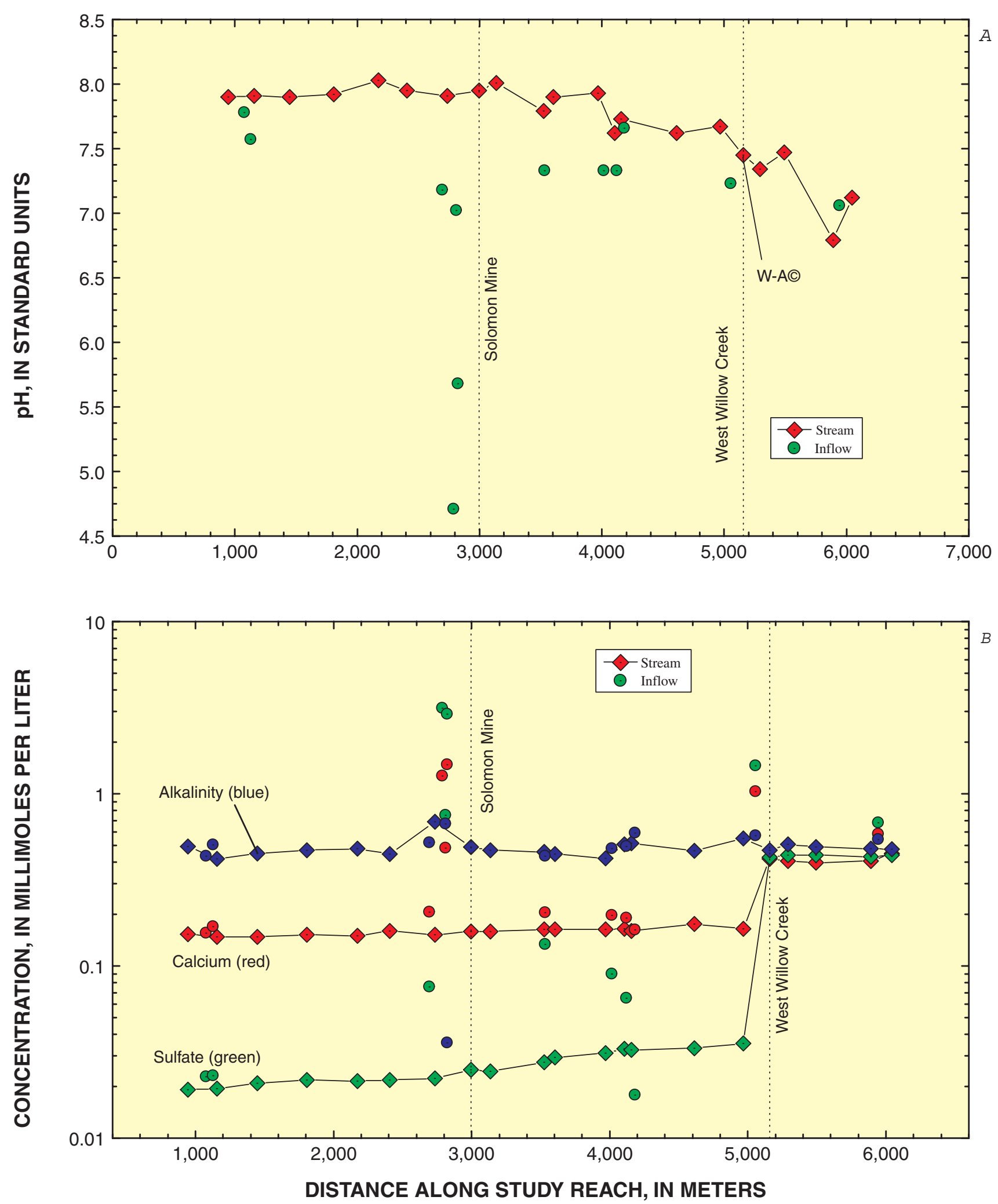

Figure 19. Variation of (A) pH and (B) calcium, sulfate, and alkalinity concentration with distance along the study reach, East Willow Creek, Colorado, August 2000. 


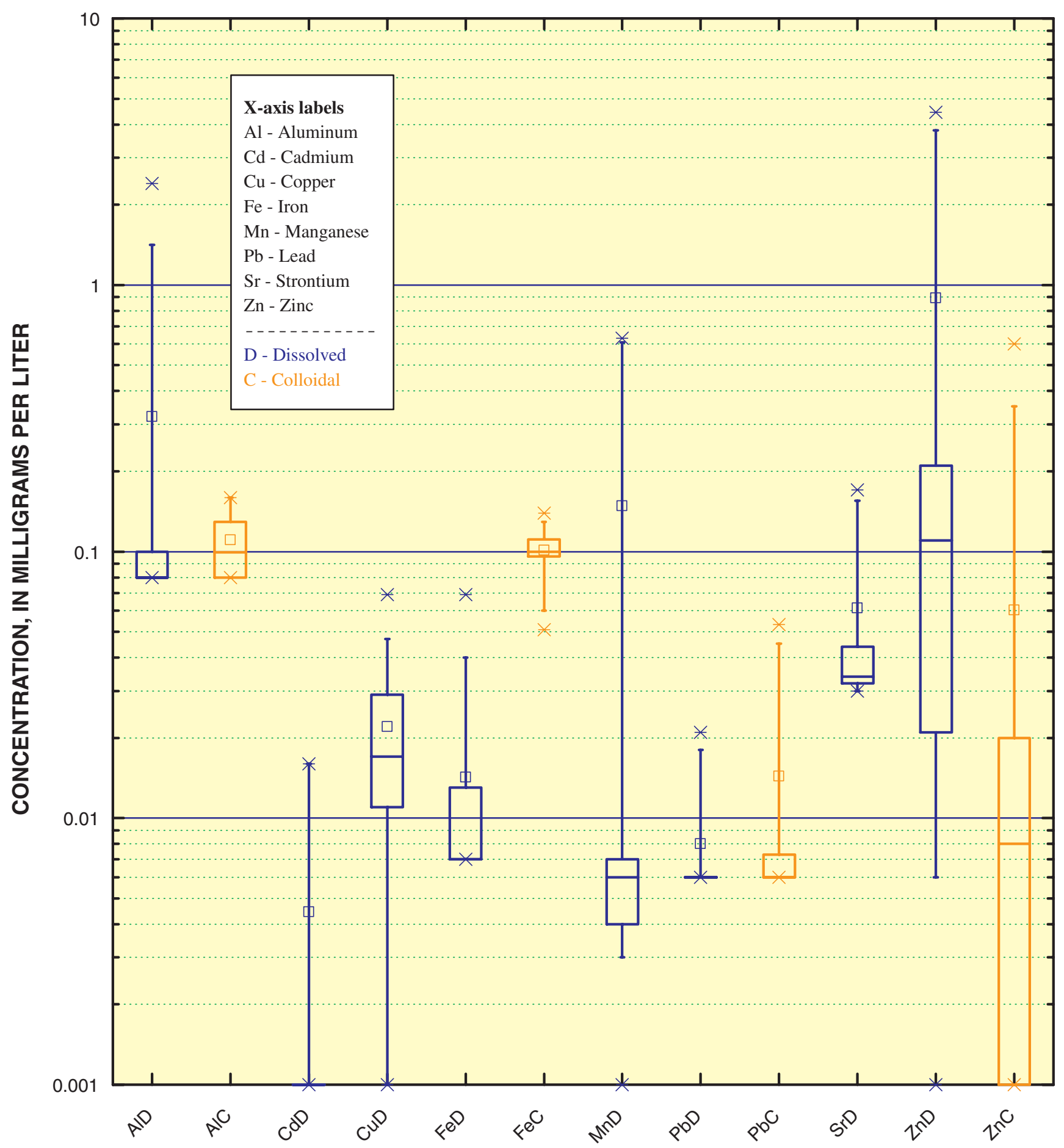

Figure 20. Distribution of dissolved (blue) and collodial (orange) metal concentration in synoptic stream samples, East Willow Creek, Colorado, August 2000. 


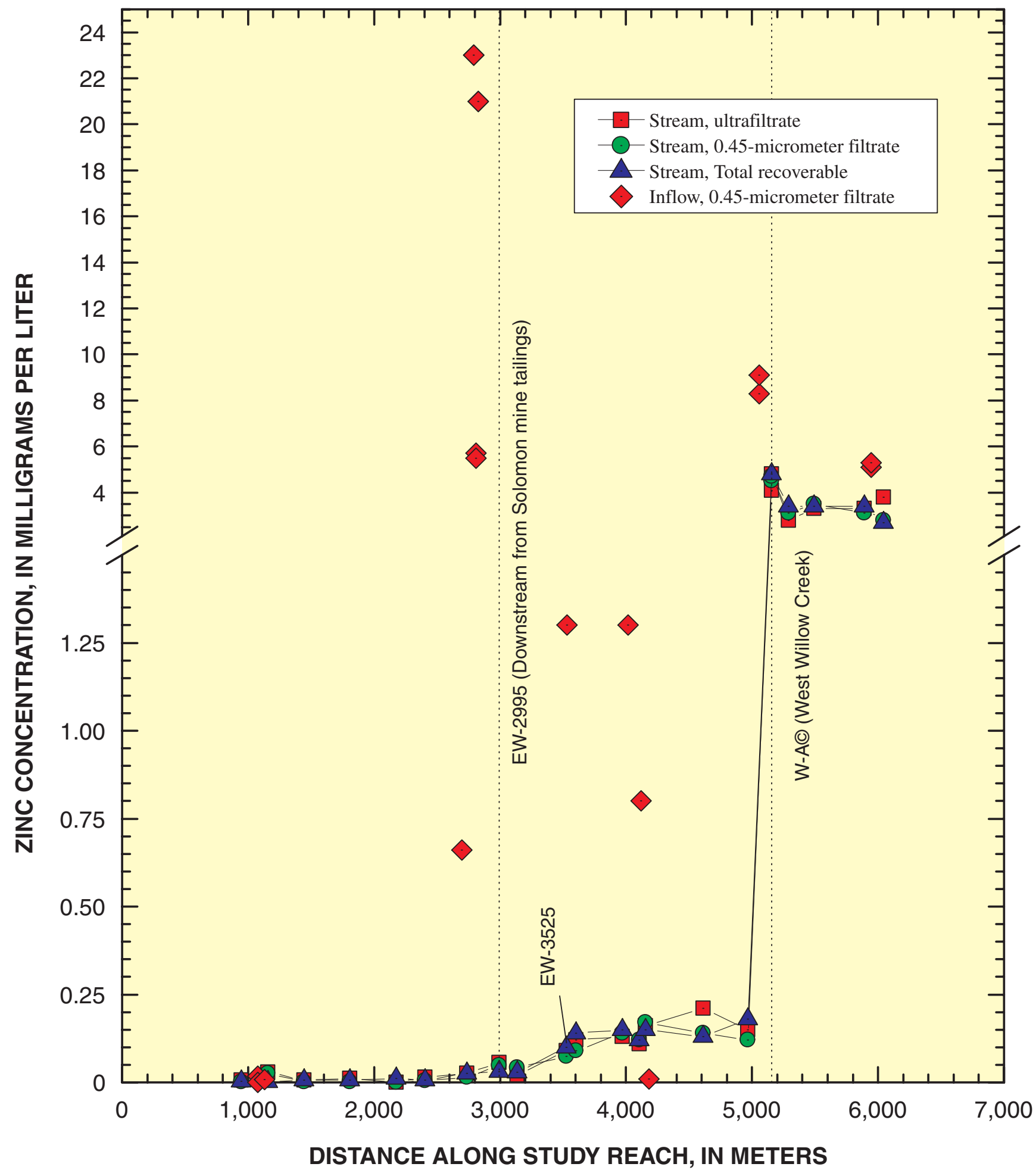

Figure 21. Variation of zinc concentration with distance along the study reach, East Willow Creek, Colorado, August 2000. 


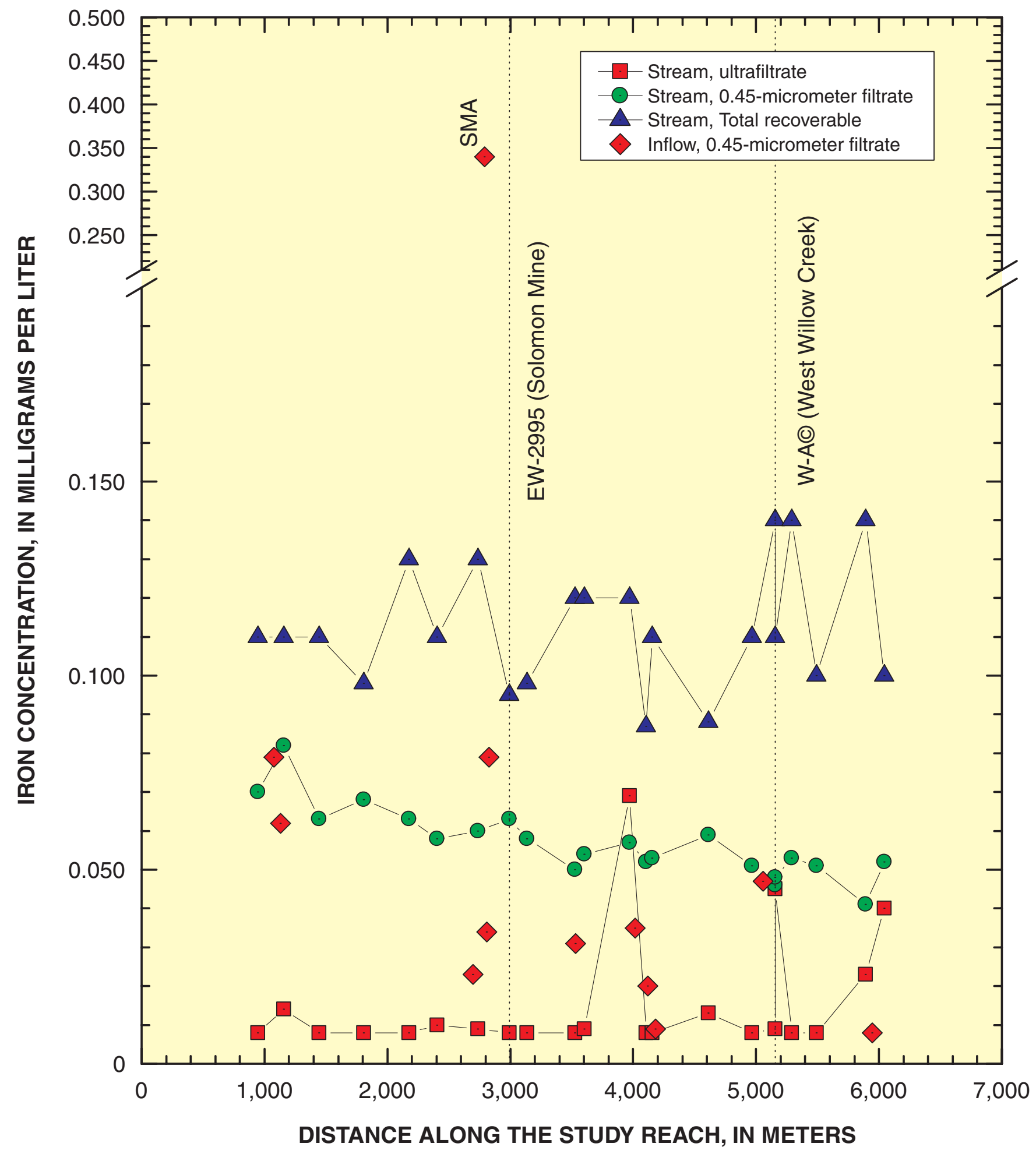

Figure 22. Variation of iron concentration with distance along the study reach, East Willow Creek, Colorado, August 2000. 


\section{SCALED PRINCIPAL COMPONENT 1 LOADINGS}

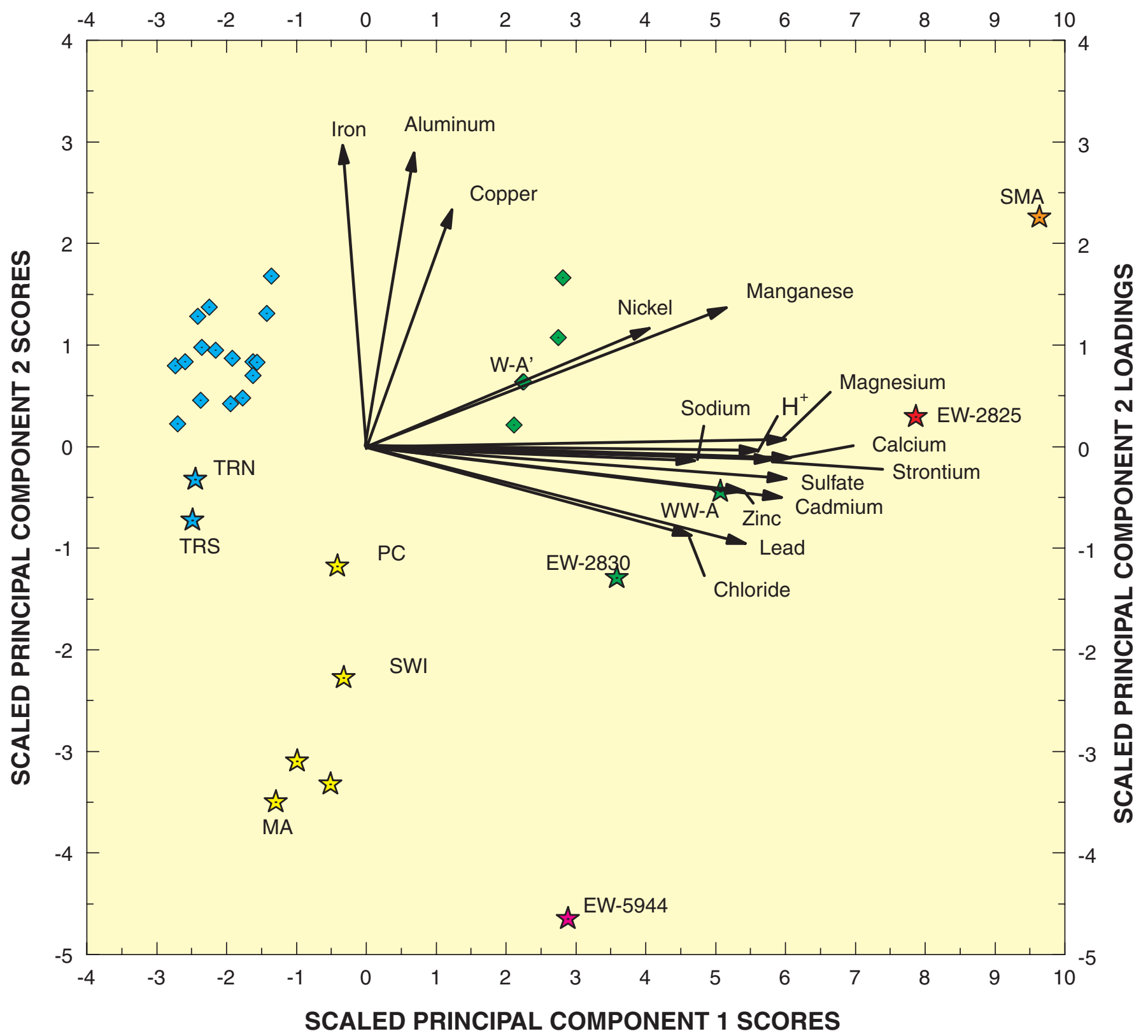

Figure 23. Biplot indicating classification of synoptic samples from East Willow Creek, Colorado, August 2000.

For both stream (diamonds) and inflow (stars) samples, groups are indicated by color: Group 1 (blue), group 2 (green), group 3 (yellow), group 4 (orange), group 5 (red), and group 6 (magenta). 
Load Profiles

Load profiles for solutes in East Willow Creek are presented for the entire study reach (table 5). To compare the summary values for cumulative instream load in table 5 to the inflow values in table 2 , the sum should only be through EW-A. For example, the cumulative instream load for $\mathrm{Al}$ along the East Willow Creek study reach was $7.94 \mathrm{~kg} /$ day, but $2.38 \mathrm{~kg} /$ day of that total was added by West Willow Creek in segment W-A'. Therefore, the load from East Willow Creek would be only $5.56 \mathrm{~kg} / \mathrm{day}$. Copper is not included in the summary because concentrations were too close to the detection limit.

Load profiles for East Willow Creek had two patterns. First, those elements that had very little loading along the study reach upstream from EW-A included $\mathrm{SO}_{4}$ (fig. 24), $\mathrm{Sr}$ (fig. 25), $\mathrm{Mn}$ (fig. 26), and $\mathrm{Zn}$ (fig. 27). Load profiles of these elements indicate that essentially all of the load came from West Willow Creek. The sample from WW-A accounted for all the increase in $\mathrm{SO}_{4}$ (fig. 24B), Sr (fig. 25B), and Mn (fig. 26B). Part of the increase in $\mathrm{Zn}$ was unsampled inflow (fig. 27B). This could indicate the occurrence of substantial subsurface inflow that had high Zn concentrations from West Willow Creek.

Load profiles for $\mathrm{Al}$ (fig. 28) and Fe (fig. 29) were very different from those of the first group. The cumulative loads at the mouth of East Willow Creek were comparable to the loads from West Willow Creek, and so downstream from the confluence, both these loads essentially doubled. The mass balance between the two tracer-injection studies was very good. For both $\mathrm{Al}$ and $\mathrm{Fe}$ the load was transported in the colloidal phase, unlike $\mathrm{SO}_{4}, \mathrm{Sr}, \mathrm{Mn}$, and $\mathrm{Zn}$, which were transported in the dissolved phase.

Although the Solomon Mine area provided an increase in the $\mathrm{Al}$ load, the majority of $\mathrm{Al}$ was contributed upstream from the study reach. A considerable load of $\mathrm{Fe}$ also was contributed upstream from the study reach, but very little was contributed by the Solomon Mine. The small loading of $\mathrm{Al}$ and the lack of loading for other metals except $\mathrm{Zn}$ could be a result of the passive wetlands at the Solomon adit. No historical data are included in this study to enable a comparison, but the stakeholder group has collected data that may help evaluate the influence of the wetland.

\section{Principal Locations of Mass Loading}

Only $\mathrm{Al}$ and $\mathrm{Fe}$ had significant loadings in the study reach upstream from West Willow Creek (table 5). However, the magnitude of the $\mathrm{Al}$ and $\mathrm{Fe}$ loads in comparison to those of West Willow Creek were about equal (figs. 28 and 29). Among the other solutes, only $\mathrm{Zn}$ had any substantial loading, but the $\mathrm{Zn}$ load was very small in comparison to the loading from West Willow Creek. Thus, in comparison to West Willow Creek and the portion of Willow Creek downstream from the confluence, the study reach of East Willow Creek upstream from the confluence with West Willow Creek was not a significant contributor to metal and $\mathrm{SO}_{4}$ loads.

\section{Unsampled Inflow}

For the entire study reach, most of the unsampled inflow occurred downstream from the confluence with West Willow Creek. The reach upstream from the confluence accounted for only a small portion of the overall load of any metal, and the unsampled inflow ranged from less than 1 percent for $\mathrm{Mn}$ and $\mathrm{SO}_{4}$ to 49 percent for Fe.

\section{Attenuation of Metals}

Attenuation ranged from less than 1 percent for Fe to 28 percent for $\mathrm{Zn}$ in East Willow Creek (table 5). However, the magnitude of loads was so small in comparison to West Willow Creek that it was not comparable.

\section{Lower Willow Creek}

The tracer injection in lower Willow Creek investigated a 2,912-m section of the Willow Creek drainage, starting near the end of the engineered section of the stream at the south end of Creede, and continued to the Rio Grande River downstream from the confluence with Willow Creek (fig. 30). The hydrology of this stream reach was complicated by braids in the stream, and samples did not represent a longitudinal profile of stream segments as they did in East and West Willow Creeks. However, it was possible to calculate mass balance for important aspects of the study reach. Sample sites for the Lower Willow injection reach as well as important field and discharge 
Table 5. Summary of load calculations, East Willow Creek, Colorado, August 2000

[Loads reported in kilograms per day, except percentages; italicized bold numbers in parentheses indicate rank for the five greatest loads of each constituent]

\begin{tabular}{|c|c|c|c|c|c|c|c|c|c|}
\hline $\begin{array}{l}\text { Segment } \\
\text { name }\end{array}$ & $\begin{array}{l}\text { Distance, } \\
\text { in meters }\end{array}$ & Aluminum & Cadmium & Iron & Manganese & Lead & Strontium & Zinc & Sulfate \\
\hline \multicolumn{10}{|c|}{ East Willow Creek } \\
\hline EW-T0 & 947 & (1)3.39 & (4)0.048 & (2)3.22 & 0.109 & 0.048 & (3)0.943 & 0.197 & (3)53.9 \\
\hline EW-K & 1,157 & .002 & .0 & .002 & .030 & .0 & -.058 & .678 & .916 \\
\hline EW-J & 1,447 & .066 & .001 & (5).062 & .033 & .001 & .017 & -.644 & 5.57 \\
\hline EW-1807 & 1,807 & .019 & .0 & .018 & .001 & .0 & .065 & .122 & 2.44 \\
\hline EW-2175 & 2,175 & -.006 & .0 & -.006 & .099 & .0 & -.002 & -.022 & -.720 \\
\hline EW-I & 2,405 & .044 & .0 & .042 & -.158 & .0 & .073 & .148 & 1.70 \\
\hline EW-H & 2,735 & .044 & .0 & .042 & .165 & .0 & -.080 & .324 & 2.04 \\
\hline EW-2995 & 2,995 & .046 & .0 & .043 & -.037 & .001 & .106 & 1.00 & 9.30 \\
\hline EW-G & 3,135 & .049 & .0 & .046 & -.028 & .001 & -.017 & -.887 & -.884 \\
\hline EW-3525 & 3,525 & (3) 1.41 & .012 & .055 & (5).207 & (4). 2365 & .081 & (3)2.30 & 11.2 \\
\hline EW-E & 3,602 & .084 & .001 & .059 & -.059 & -.022 & .052 & 1.374 & 7.00 \\
\hline EW-D & 3,970 & .079 & -.011 & .055 & -.028 & -.212 & -.048 & .403 & 7.08 \\
\hline EW-4107 & 4,107 & -.554 & .0 & .054 & -.140 & .0 & .051 & -.939 & 7.23 \\
\hline EW-C & 4,157 & (5).088 & .001 & (4). 070 & .152 & .001 & -.012 & (5)1.48 & .985 \\
\hline EW-B & 4,613 & (4).207 & (5).014 & (3). 163 & -.068 & .002 & (5).410 & (4) 2.04 & 7.19 \\
\hline EW-A & 4,968 & .034 & -.012 & .027 & -.023 & (3). 273 & -.278 & -1.06 & 8.03 \\
\hline \multicolumn{10}{|c|}{ Downstream from confluence with West Willow Creek } \\
\hline $\mathrm{W}-\mathrm{A}$ & 5,158 & (2)2.38 & (1).828 & (1)3.53 & (1)31.8 & (1)3.39 & (1)5.64 & (1)250 & $(1) 2,070$ \\
\hline EW-5292 & 5,292 & .0 & (2).138 & .0 & (3).534 & -.350 & (4).534 & -74.8 & (2)60.3 \\
\hline EW-5492 & 5,492 & .0 & -.011 & .0 & -.534 & -.460 & .0 & .0 & (5)9.08 \\
\hline EW-5892 & 5,892 & .0 & -.038 & .0 & (4).497 & (2).380 & .0 & .0 & -52.3 \\
\hline EW-6044 & 6,044 & .0 & (3). 124 & .0 & (2).534 & (5).066 & (2) 1.60 & (2) 21.4 & (4) 52.3 \\
\hline \multicolumn{2}{|c|}{ Cumulative instream load } & 7.94 & 1.17 & 7.48 & 34.2 & 4.40 & 11.0 & 281 & 2,320 \\
\hline \multicolumn{2}{|c|}{ Cumulative inflow load } & 6.48 & .98 & 3.79 & 37.7 & 2.40 & 7.63 & 158 & 2,560 \\
\hline \multicolumn{2}{|c|}{ Percent inflow load } & 82.0 & 84 & 51 & 110 & 55 & 69 & 56 & 110 \\
\hline \multicolumn{2}{|c|}{ Attenuation } & .560 & .07 & $<.01$ & 1.08 & 1.04 & .58 & 78 & 54.0 \\
\hline \multicolumn{2}{|c|}{ Percent attenuation } & 7 & 6 & $<1$ & 3 & 24 & 5 & 28 & 2 \\
\hline \multicolumn{2}{|c|}{ Unsampled inflow } & 1.46 & .19 & 3.69 & $<1$ & 2.00 & 3.37 & 123 & $<1$ \\
\hline \multicolumn{2}{|c|}{ Percent unsampled inflow } & 18.0 & 16 & 49 & $<1$ & 45 & 31 & 44 & $<1$ \\
\hline
\end{tabular}



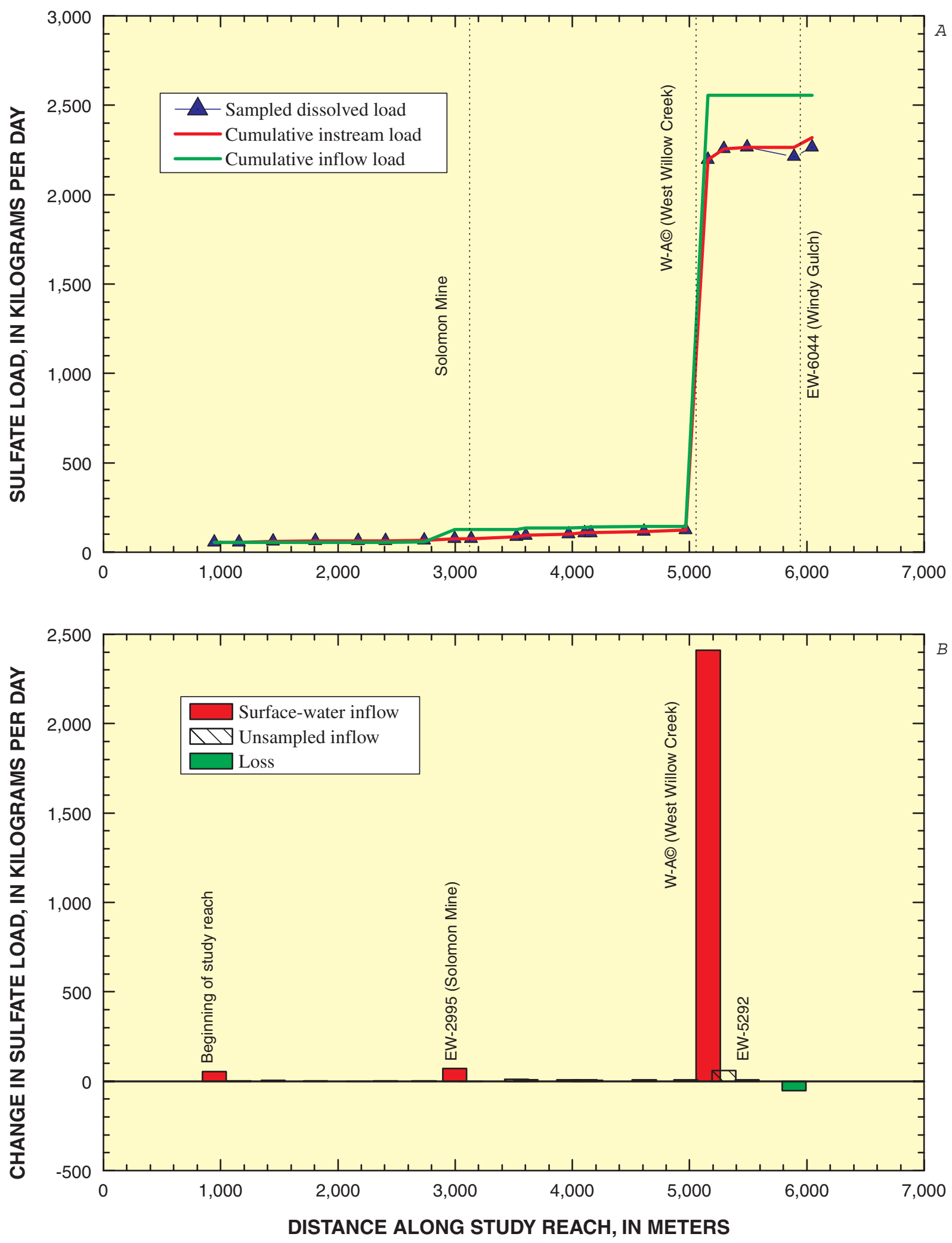

Figure 24. (A) Variation of sulfate load with distance and (B) changes in sulfate load for individual stream segments, East Willow Creek, Colorado, August 2000. 

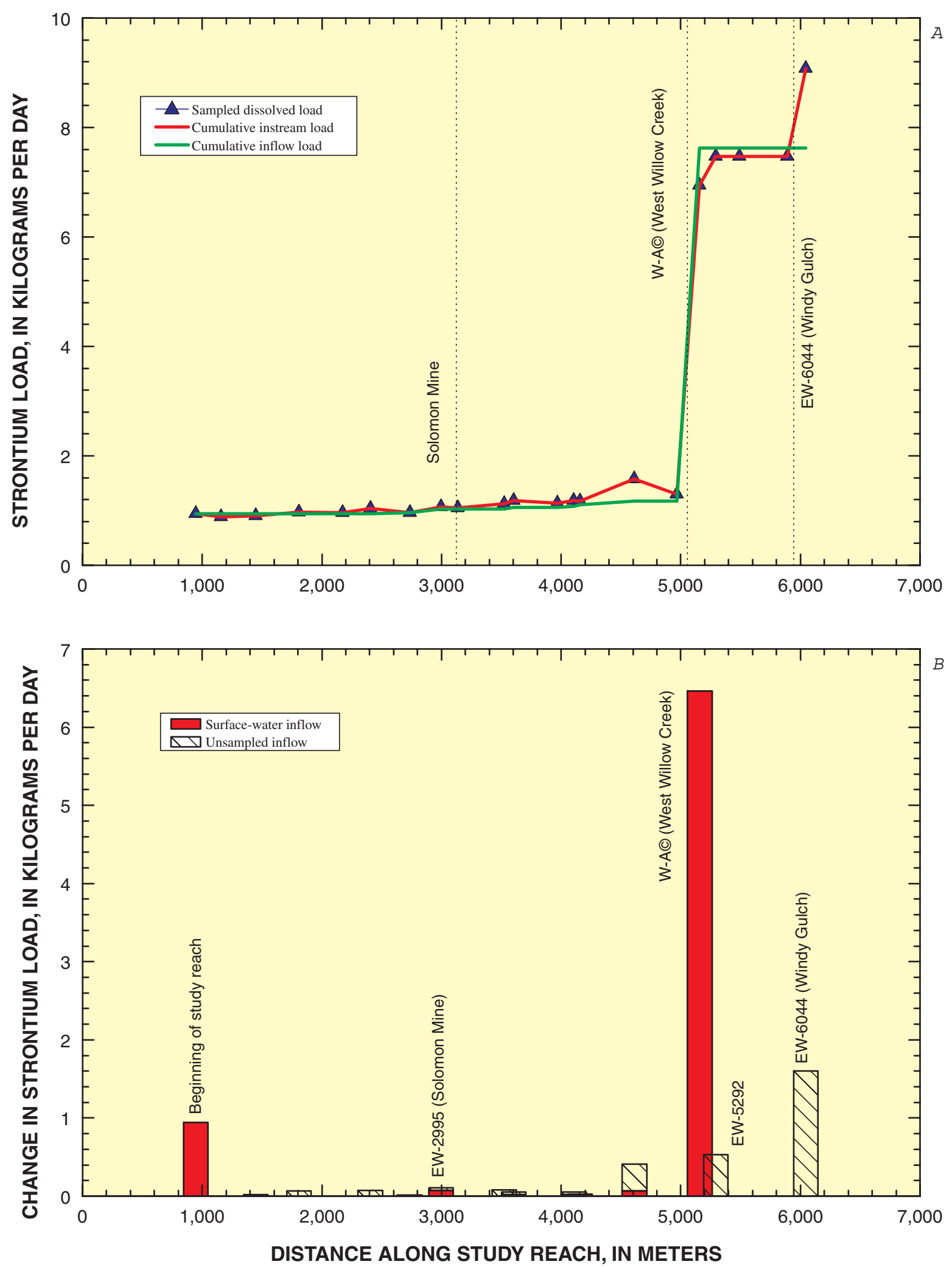

Figure 25. (A) Variation of strontium load with distance and (B) changes in strontium load for individual stream segments, East Willow Creek, Colorado, August 2000. 

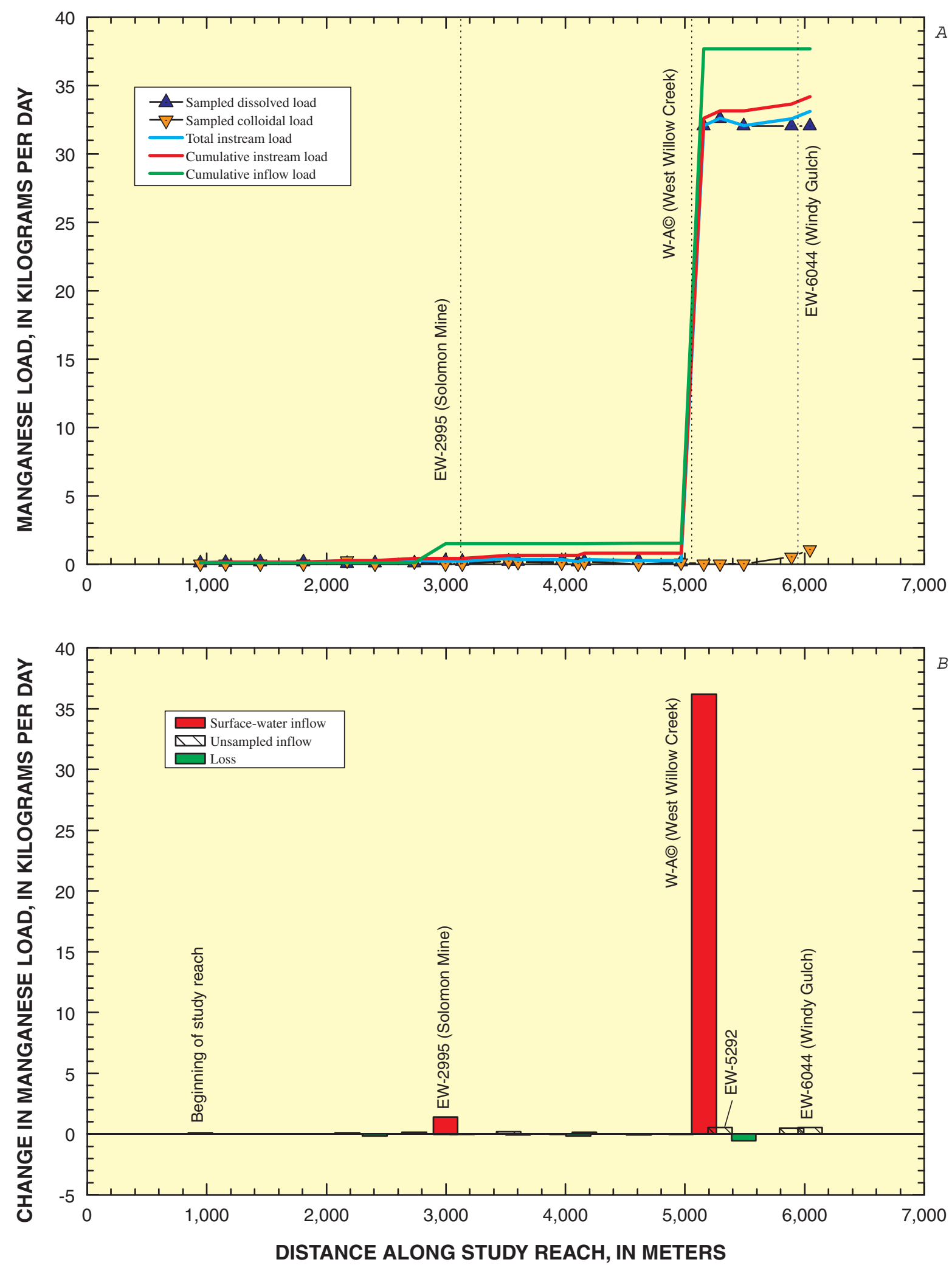

Figure 26. (A) Variation of manganese load with distance and (B) changes in manganese load for individual stream segments, East Willow Creek, Colorado, August 2000. 

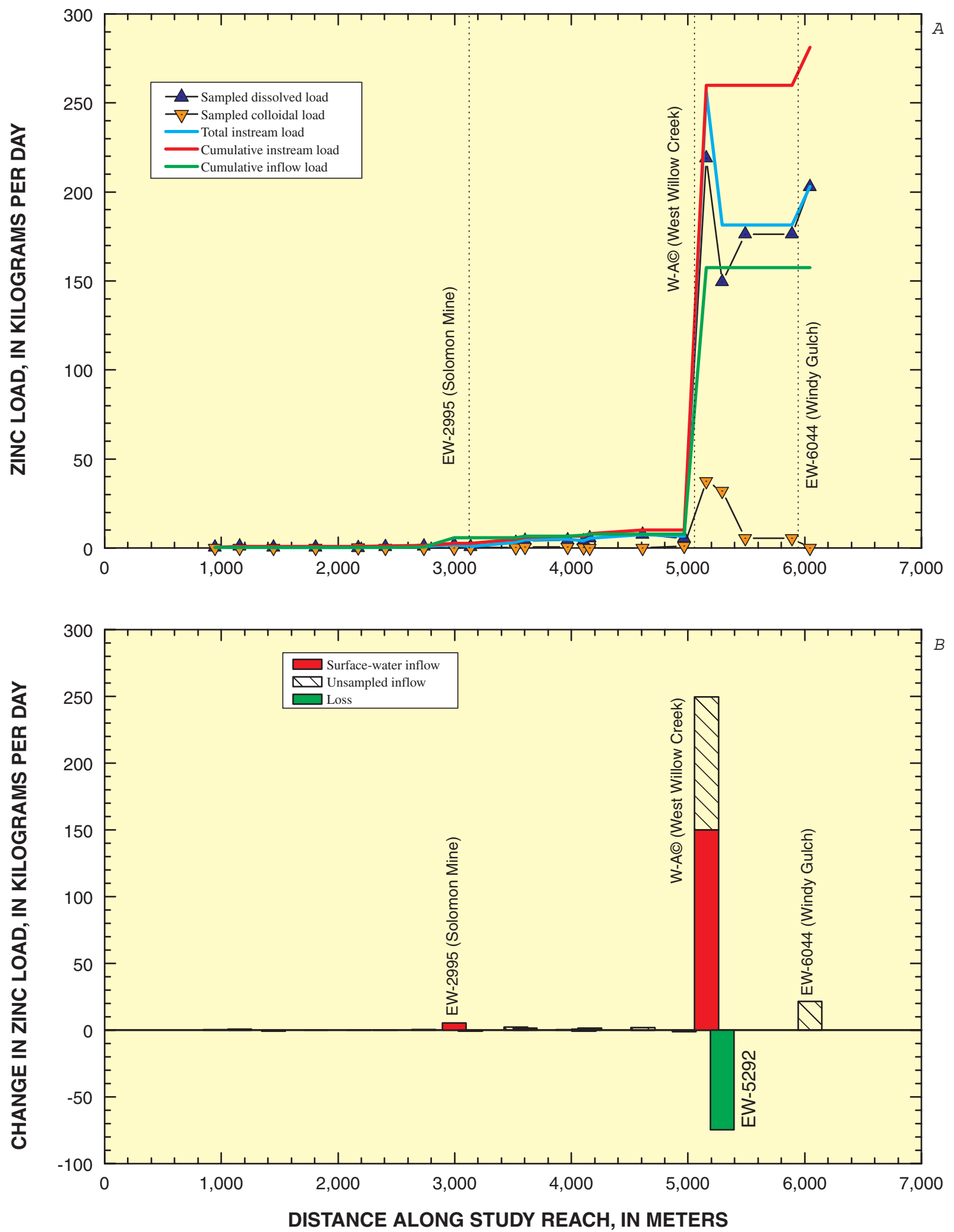

Figure 27. (A) Variation of zinc load with distance and (B) changes in zinc load for individual stream segments, East Willow Creek, Colorado, August 2000. 

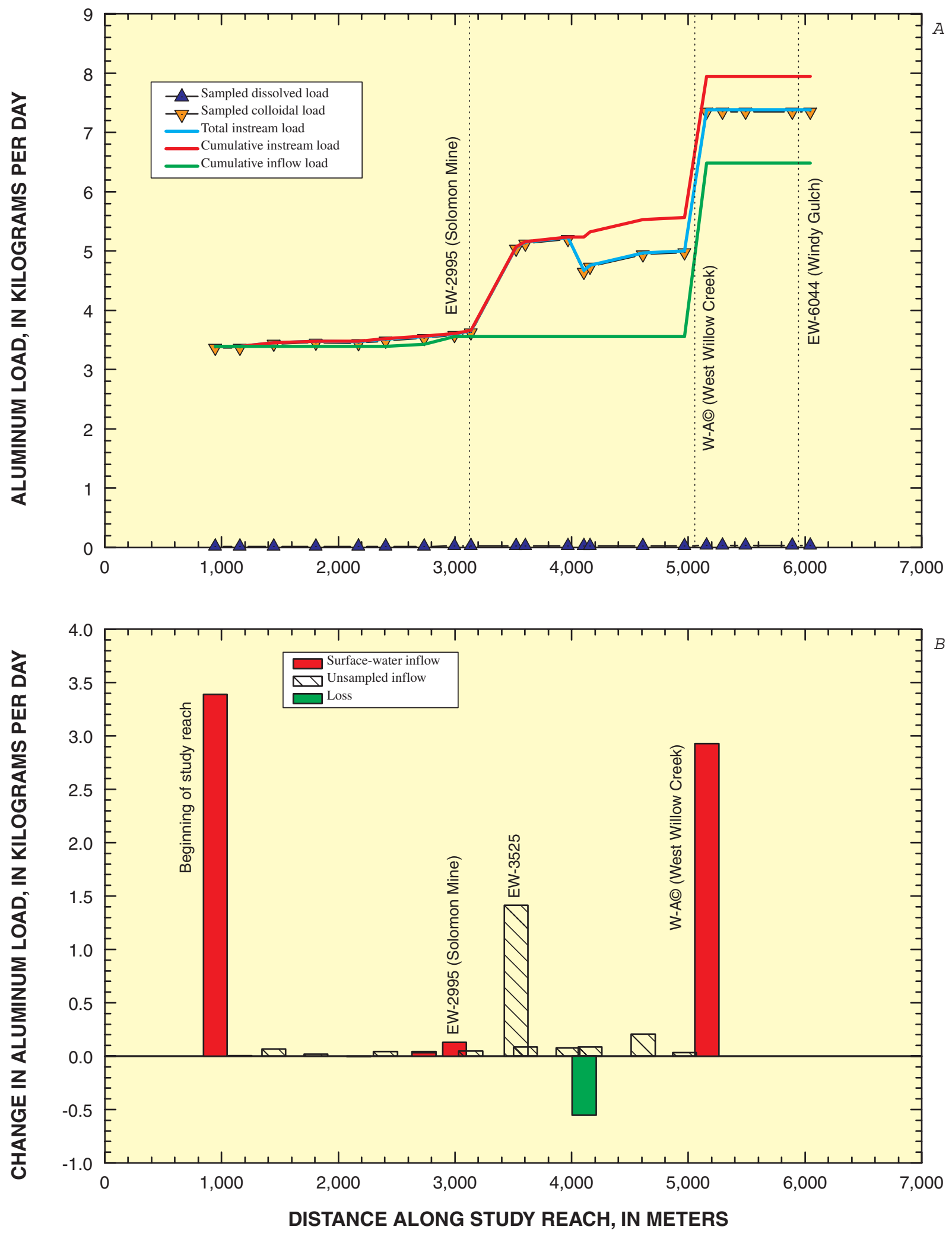

Figure 28. (A) Variation of aluminum load with distance and (B) changes in aluminum load for individual stream segments, East Willow Creek, Colorado, August 2000. 

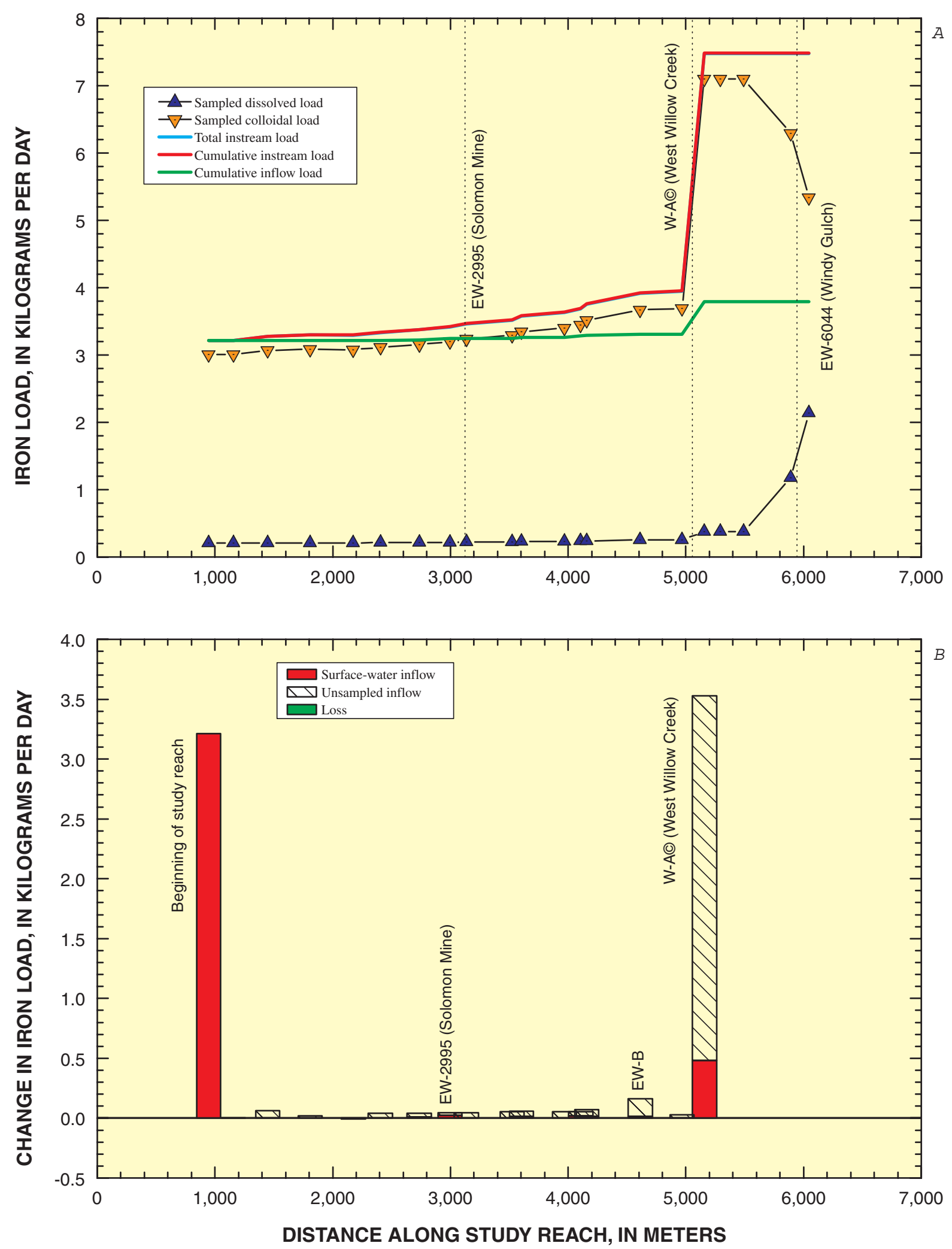

Figure 29. (A) Variation of iron load with distance and (B) changes in iron load for individual stream segments, East Willow Creek, Colorado, August 2000. 


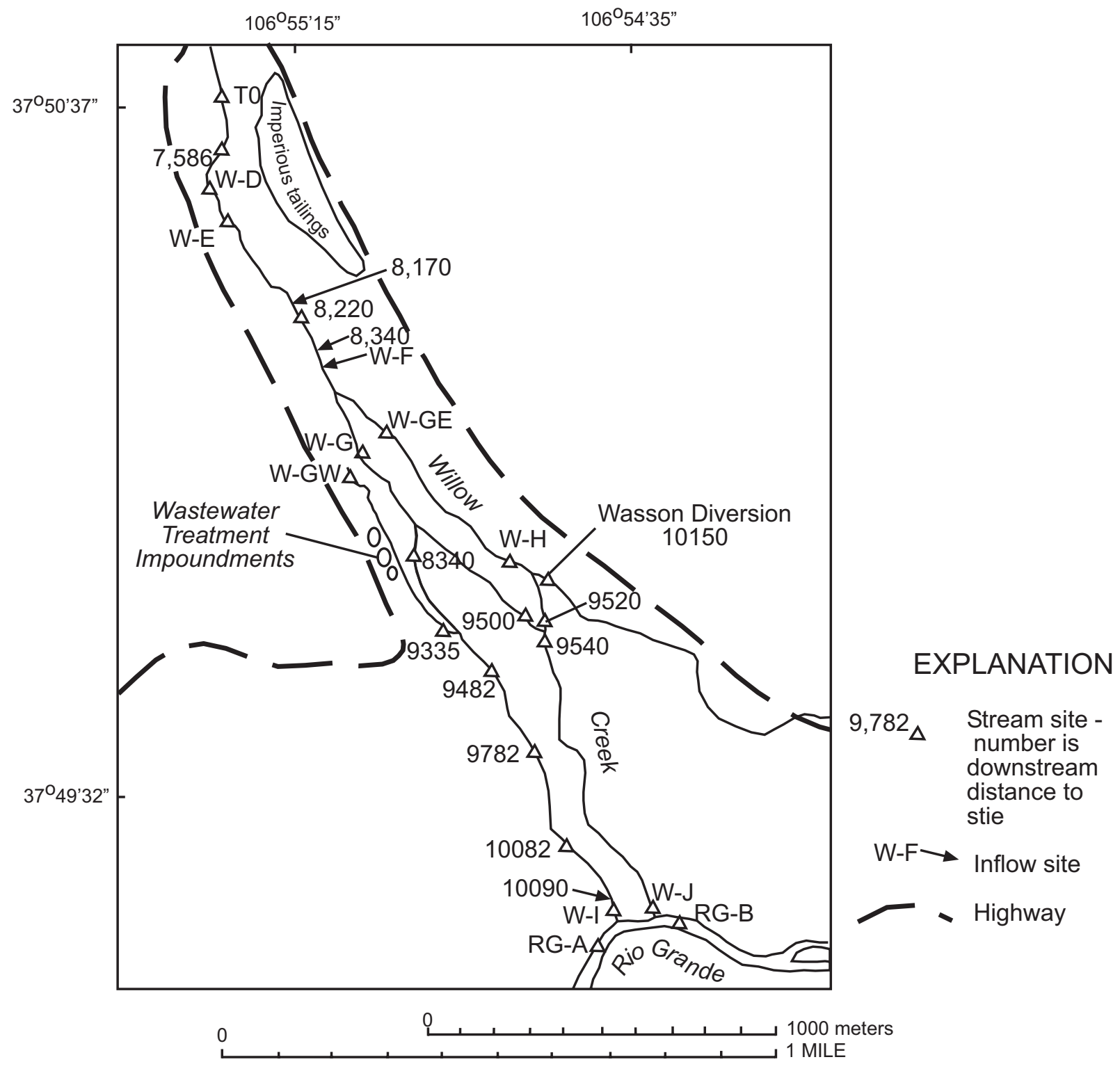

Figure 30. Location of synoptic sampling sites, lower Willow Creek, near Creede, Colorado, August 2000. 
data are listed in table 6. Inflow from the Creede sewage treatment plant may have occurred along the west side of the study reach. Along the east side, acidic inflow was likely from the Imperious tailings (fig. 30). Otherwise, only a few obvious inflows along the study reach were observed. A diversion of 29 percent of the water occurred at the Wasson gate (LW-10150). Although this resulted in a loss of mass, it was possible to account for this in the load calculations.

\section{Discharge}

A $\mathrm{NaBr}$ tracer with a $\mathrm{Br}$ concentration of $151,900 \mathrm{mg} / \mathrm{L}$ was injected at a rate of $0.0043 \mathrm{~L} / \mathrm{s}$. Straightforward application of equation 1 for determining discharge was not possible because of extensive braiding that occurs in this lower reach. Numerous discharge estimates based on traditional velocity-area measurements (Rantz and others, 1982) were therefore combined with tracer-dilution data to provide a description of discharge. Discharge estimates for sites above the braided area (W-D, W-E, and LW-8220) were first calculated by using equation 1. Velocity-area measurements were then used to assign discharge to a number of additional sites (LW9500, LW-9520, LW-9540, W-H, LW-10150, W-I, and W-J). Discharges at the remaining sites were given by:

$$
Q_{D}=\frac{Q_{U}\left(C_{U}-C_{D}\right)}{C_{D}-C_{L}}
$$

where:

$$
\begin{aligned}
Q_{U}= & \text { stream discharge at the upstream site, } \\
& \text { in } \mathrm{L} / \mathrm{s}, \\
C_{U}= & \text { the tracer concentration at the } \\
& \text { upstream site, in } \mathrm{mg} / \mathrm{L}, \\
C_{D}= & \text { the tracer concentration at the } \\
& \text { downstream site, in } \mathrm{mg} / \mathrm{L}, \text { and } \\
C_{L}= & \text { the inflow concentration (of water } \\
& \text { entering between two stream sites). }
\end{aligned}
$$

For example, discharge at W-I, which is downstream from LW-10082, was estimated from the upstream discharge at LW-10082 $\left(Q_{U}\right)$, the upstream concentration at LW-10082 $\left(C_{U}\right)$, the downstream concentration at W-I $\left(C_{D}\right)$, and the inflow concentration at LW-10090 $\left(C_{L}\right)$ (fig. 31).

\section{Chemical Characterization of Synoptic Samples}

Concentrations along the study reach are difficult to track because the braiding of the stream caused variations to a simple longitudinal profile. There were essentially three different longitudinal paths through the study reach, defined as follows:

1. From the injection site, path 1 follows the eastern braid to W-H, and then a part goes to LW-9520 and from there to the mouth of Willow Creek at W-J.

2. From the central braid, at W-G, the stream continues to the mouth of Willow Creek at W-I.

3. On the west side of the study reach, a stream starts upstream from W-G West, passes the Sewage Treatment Plant (STP), and joins path 2 at LW9482.

The stream was mostly a calcium sulfate type water in all of the braids. The Rio Grande River near Willow Creek was a calcium bicarbonate type. Values of $\mathrm{pH}$ were generally between 7.0 and 7.5 (fig. 32). The effect of acidic inflows may have started at LW-8220, but values just downstream were again near 7.5. $\mathrm{pH}$ in the Rio Grande River was higher than in the study reach of Willow Creek.

Concentrations of $\mathrm{Al}, \mathrm{Fe}, \mathrm{Mn}$, and $\mathrm{Zn}$ were relatively high along the study reach (fig. 33). Both $\mathrm{Al}$ and Fe were present mostly as colloids. There was some colloidal $\mathrm{Zn}$, but concentrations of dissolved $\mathrm{Zn}$ were much higher. The spatial variation of metals gives an indication of the importance of the Imperious tailings and other sources. The pattern of $\mathrm{SO}_{4}$ concentration indicates that concentrations were higher in the east braid (path 1) than in the central braid (fig. 34). This could be from the inflow of W-F and LW8340. However, the concentration of $\mathrm{SO}_{4}$ in the west braid (path 3) was substantially higher. The source of this $\mathrm{SO}_{4}$ is not clear because this braid started just upstream from the sampling site. Water entering the Rio Grande River along path 1 had a higher $\mathrm{SO}_{4}$ concentration than along path 2 , but they were not very different.

The pattern of $\mathrm{Mn}$ was different from that of $\mathrm{SO}_{4}$ (fig. 35). There was a distinction between concentrations in the east and middle braids (paths 1 and 2), but concentrations in the west braid (path 3) were lower. Concentrations of $\mathrm{Zn}$ were similar to those of $\mathrm{SO}_{4}$ because the west braid (path 3 ) had higher $\mathrm{Zn}$ concentrations than the other two paths (fig. 36). 
Table 6. Synoptic sampling sites, lower Willow Creek, Colorado, August 2000

\begin{tabular}{|c|c|c|c|c|c|c|c|}
\hline $\begin{array}{c}\text { Segment } \\
\text { identification }\end{array}$ & Source & $\begin{array}{l}\text { Distance, } \\
\text { in meters }\end{array}$ & Site description & $\begin{array}{c}\mathrm{pH}, \text { in } \\
\text { standard } \\
\text { units }\end{array}$ & $\begin{array}{c}\text { Specific } \\
\text { conductance, } \\
\text { in micro- } \\
\text { siemens per } \\
\text { centimeter }\end{array}$ & $\begin{array}{c}\text { Discharge, in } \\
\text { liters per } \\
\text { second }\end{array}$ & $\begin{array}{c}\text { Smoothed } \\
\text { bromide, in } \\
\text { milligrams } \\
\text { per liter }\end{array}$ \\
\hline LW-T0 & Stream & 7,443 & Upstream from injection & 7.46 & 137 & 582 & 0.04 \\
\hline LW-7586 & Stream & 7,586 & At the end of the channel at railroad bridge & 7.31 & 143 & 582 & .73 \\
\hline W-D & Stream & 7,716 & Down from trailer park sewage disposal & 7.39 & 142 & 582 & 1.02 \\
\hline W-E & Stream & 7,830 & $\mathrm{~T} 1$ - Up from braided reach & 7.43 & 141 & 588 & 1.05 \\
\hline LW-8170 & Inflow & 8,170 & $\begin{array}{l}\text { Stream return flow_may have tailings } \\
\text { seepage }\end{array}$ & 7.50 & 139 & - & - \\
\hline LW-8220 & Stream & 8,220 & Where braids come back together & 6.84 & 145 & 599 & 1.03 \\
\hline LW-8340 & Inflow & 8,340 & Seep with Ulothrix algae & 3.42 & 2,050 & - & .01 \\
\hline $\mathrm{W}-\mathrm{F}$ & Inflow & 8,450 & Seep from tailings & 2.95 & 2,770 & - & .01 \\
\hline W-G & Stream & 8,725 & Stream in middle braid $170 \mathrm{~m}$ before split & 7.46 & 144 & 304 & 1.01 \\
\hline W-G-East & Stream & 8,725 & East channel & 7.40 & 149 & 263 & .99 \\
\hline W-G-West & Stream & 8,725 & West channel with little flow & 7.17 & 176 & 31.7 & .94 \\
\hline LW-9075 & Stream & 9,075 & $\mathrm{~T} 2$ - Right part of middle braid & 7.49 & 143 & 250 & .89 \\
\hline LW-9335 & Inflow & 9,335 & Seepage from sewage treatment plant & 7.46 & 172 & 55.4 & .01 \\
\hline LW-9482 & Stream & 9,482 & Down from sewage treatment plant & 7.45 & 146 & 305 & .87 \\
\hline LW-9500 & Stream & 9,500 & Upstream from Wasson return & 7.28 & 148 & 40.3 & .87 \\
\hline LW-9520 & Inflow & 9,520 & Wasson return & 7.11 & 149 & 99.1 & \\
\hline LW-9540 & Stream & 9,540 & Down from Wasson return & 7.10 & 149 & 148 & .87 \\
\hline LW-9782 & Stream & 9,782 & Right part of middle braid & 7.38 & 147 & 308 & .88 \\
\hline LW-10082 & Stream & 10,082 & Another right part of the middle braid & 6.74 & 149 & 322 & .88 \\
\hline LW-10090 & Inflow & 10,090 & Flow along base of high berm & 6.96 & 166 & - & .01 \\
\hline W-H & Stream & 10,100 & Wasson gate & 7.21 & 150 & 265 & .88 \\
\hline LW-10150 & Stream & 10,150 & Irrigation diversion & - & - & - & - \\
\hline W-I & Stream & 10,324 & Stream near mouth of upstream braid & 7.37 & 147 & 333 & .82 \\
\hline W-J & Stream & 10,324 & Stream near mouth of downstream braid & 7.42 & 147 & 163 & .60 \\
\hline RG-A & Stream & 10,350 & Rio Grande River up from Willow Creek & 8.13 & 80 & 7,074 & .29 \\
\hline RG-B & Stream & 10,355 & Rio Grande River down from Willow Creek & 7.45 & 82 & 7,570 & .04 \\
\hline
\end{tabular}




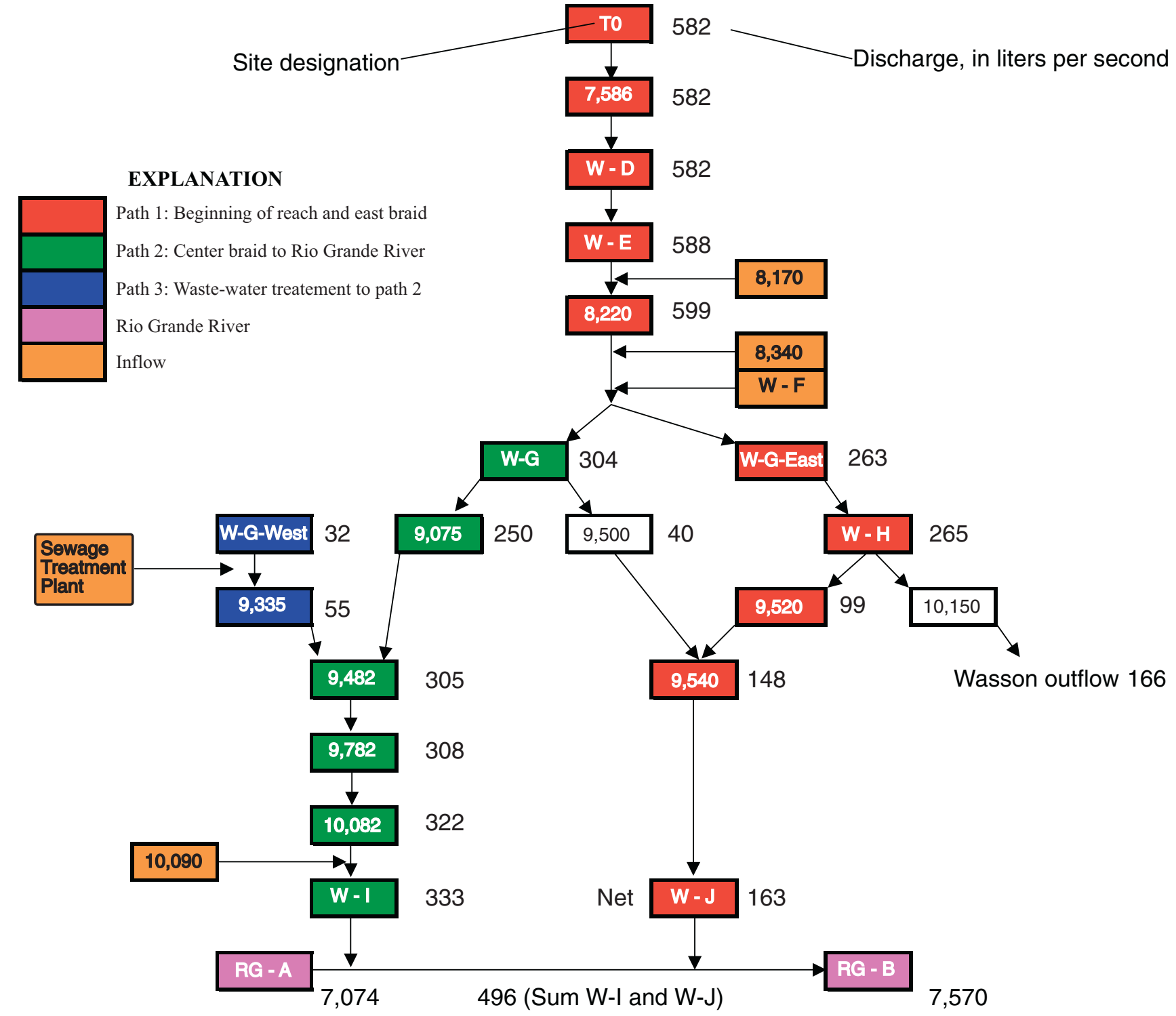

Figure 31. Discharge at sampling sites along the study reach, lower Willow Creek, Colorado, August 2000. 


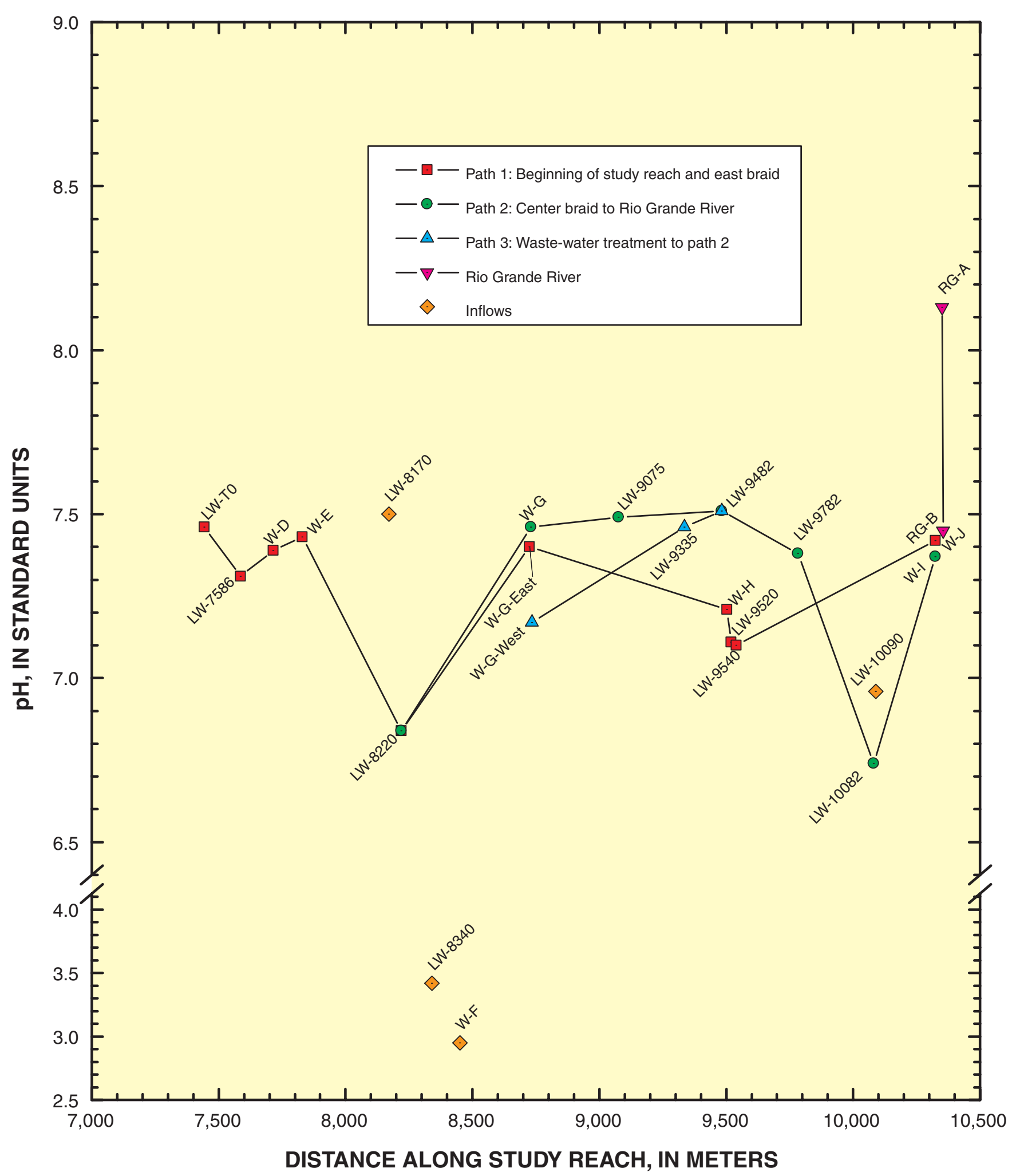

Figure 32. Variation of $\mathrm{pH}$ with distance along the study reach, indicating paths of braids, lower Willow Creek, Colorado, August 2000. 


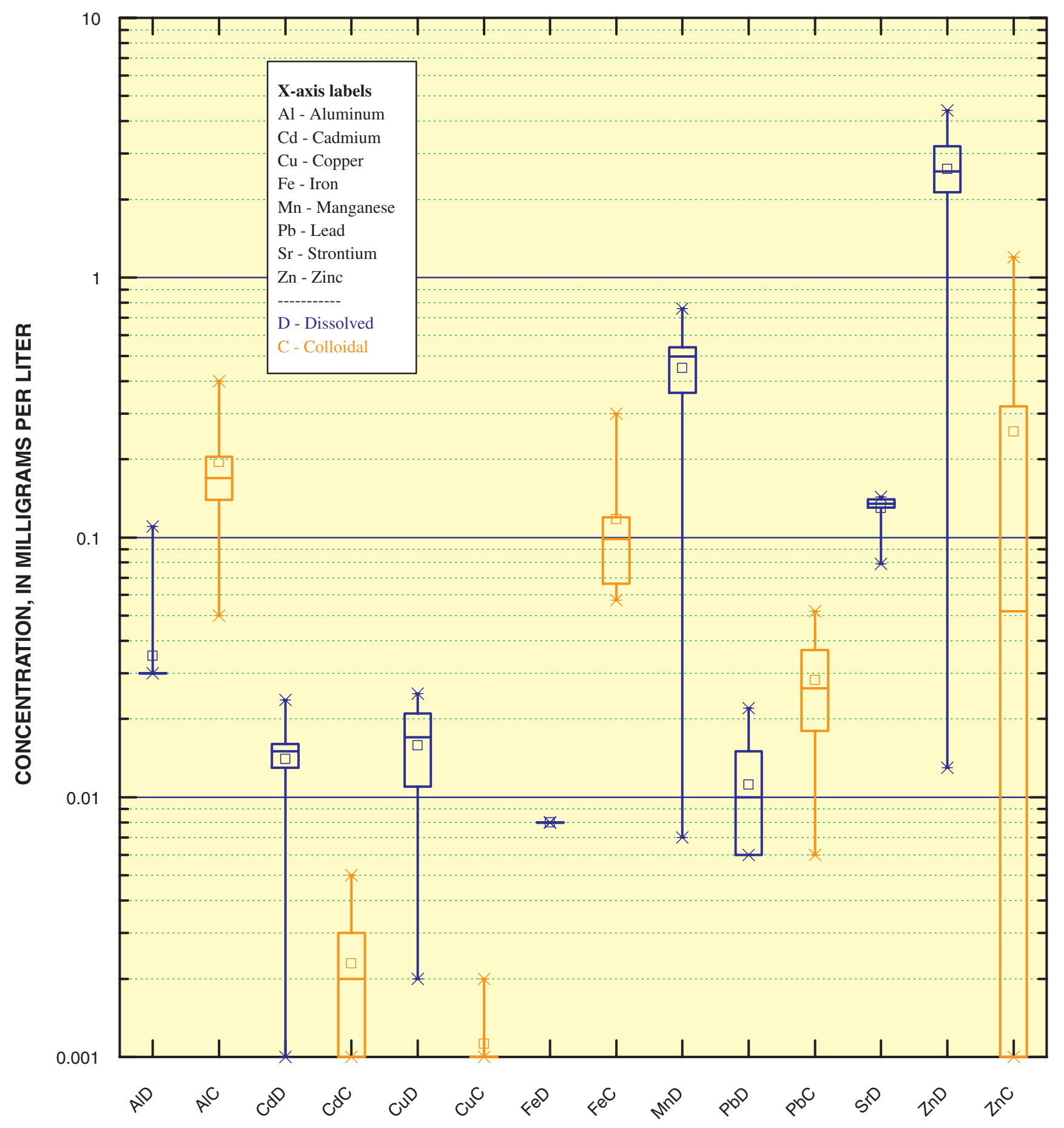

Figure 33. Distribution of selected dissolved (blue) and colloidal (orange) metal concentrations, lower Willow Creek, Colorado, August 2000. 


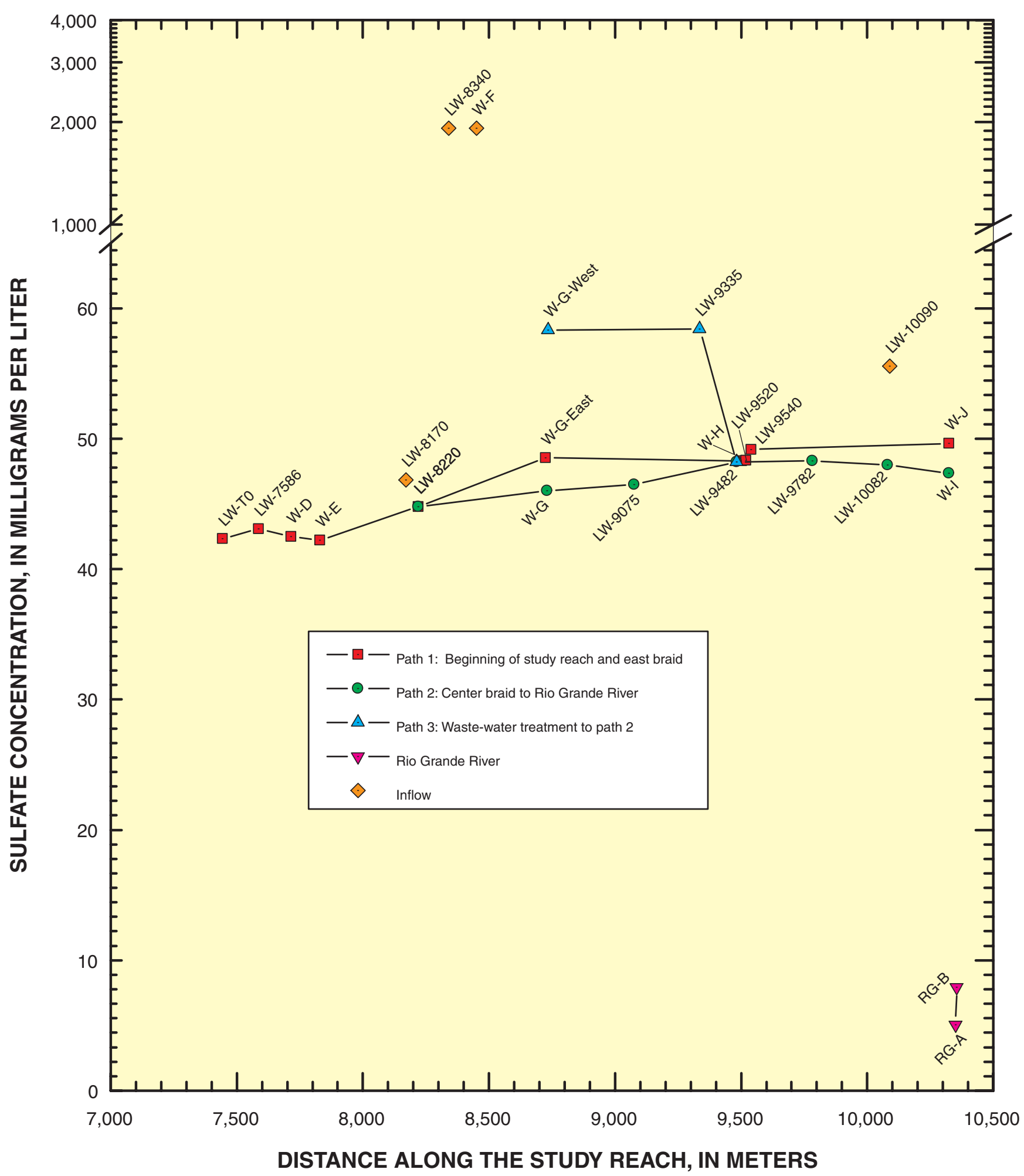

Figure 34. Variation of sulfate concentration with distance along the study reach, indicating paths of braids, lower Willow Creek, Colorado, August 2000. 


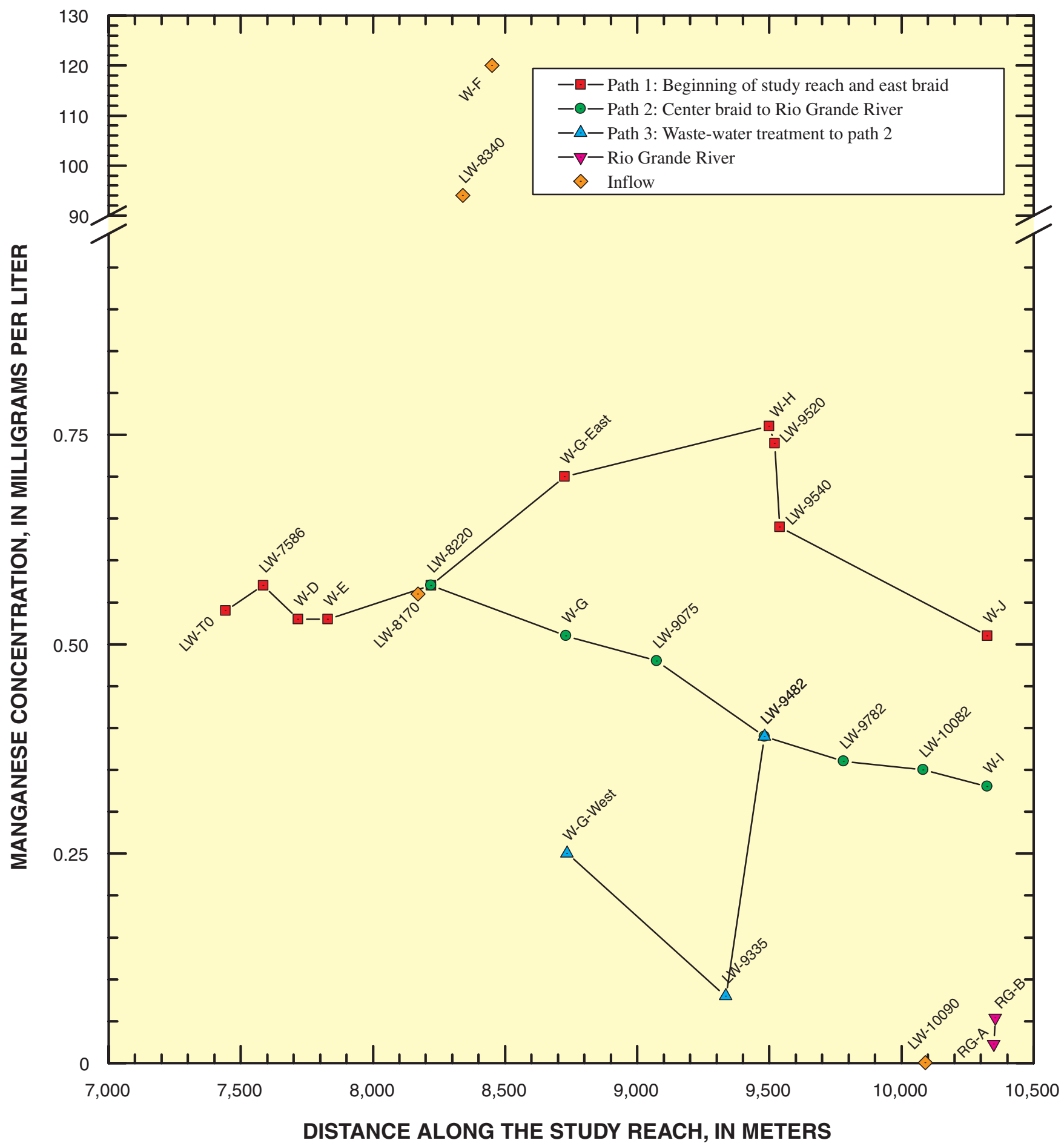

Figure 35. Variation of manganese concentration with distance along the study reach, indicating paths of braids, lower Willow Creek, Colorado, August 2000. 


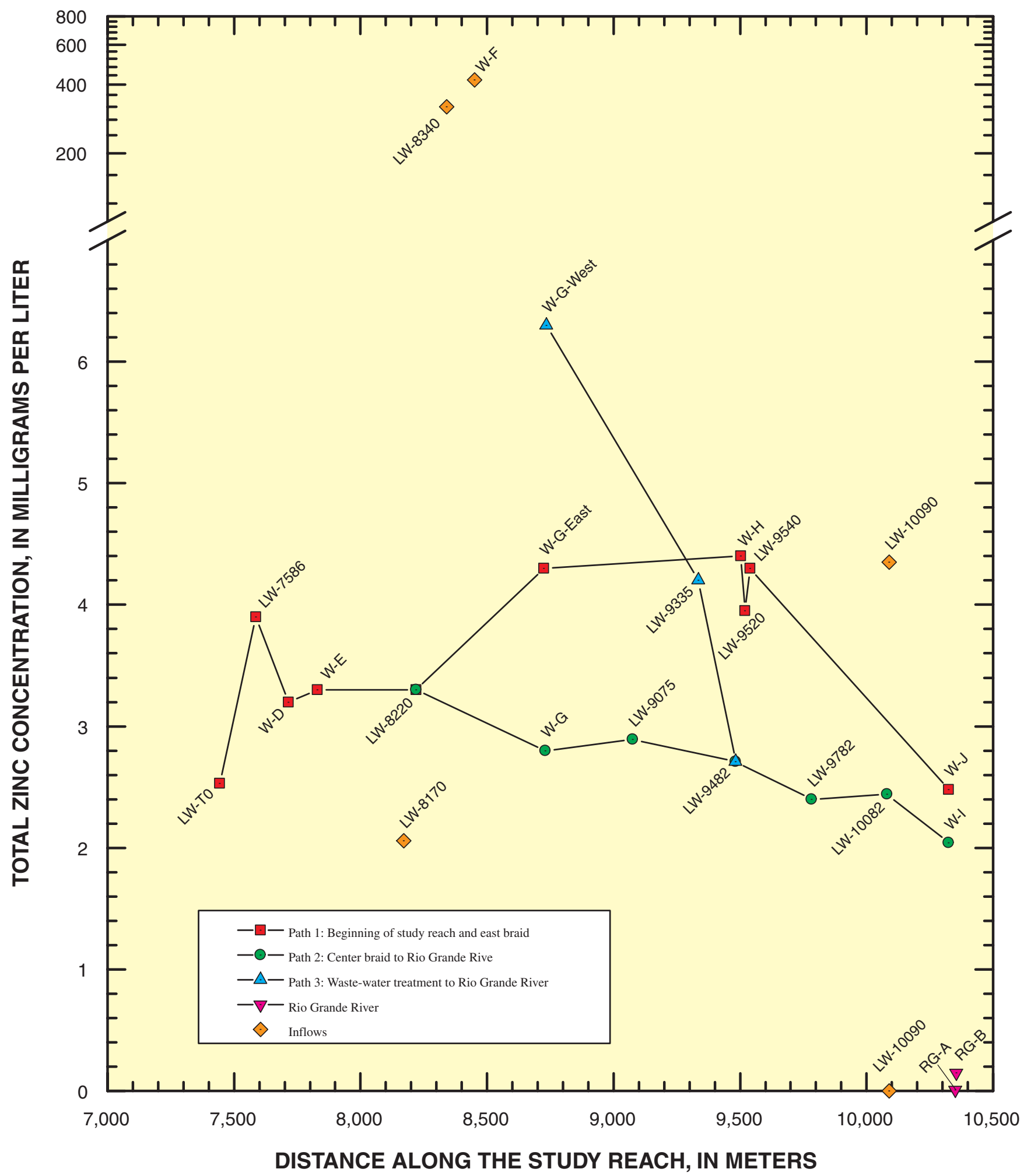

Figure 36. Variation of zinc concentration with distance along the study reach, indicating paths of braids, lower Willow Creek, Colorado, August 2000. 
Load Profiles

Patterns of loading are difficult to display in a longitudinal view for the lower Willow Creek study area. With the braiding in the stream, loads are split and at other places, they recombine. To avoid the complexity of such a plot, the loads are presented in a schematic map view, similar to the presentation of discharge. It is also difficult to present a summary of loading calculations that is similar to those for West and East Willow Creeks. However, some load calculations help identify the effect of this study reach on loads to the Rio Grande River (table 7). The first calculation is the sum of W-I and W-J. The net gain through the study reach takes this sum, adds the load leaving by the Wasson diversion, and subtracts the load at LW-8220, upstream from the beginning of braiding. Finally, the net gain for the Rio Grande River is from the difference between loads at RG-A and RG-B.

The overall effect of the lower Willow study reach was a net loss of $\mathrm{Fe}, \mathrm{Mn}$, and $\mathrm{Zn}$, and a net gain of $\mathrm{Al}$ and $\mathrm{SO}_{4}$. Overall, however, there appeared to be a net gain of $\mathrm{Al}, \mathrm{Fe}, \mathrm{Mn}, \mathrm{Zn}$, and $\mathrm{SO}_{4}$ to the Rio Grande River between the two sampling sites. Without the longitudinal profiles of load, it is difficult to determine if this increase was from unsampled inflow, but it most likely was ground-water contribution to the Rio Grande River from sources within the Willow Creek watershed.

To interpret the load diagrams for the lower Willow study, strontium can be viewed as a conservative solute through the study reach. Strontium concentration did not vary by more than a few hundredths of a milligram per liter. With that assumption, the percentage of Sr load at W-G and WG-East was 51 (3.70 of 7.25) and 44 (3.19 of 7.25) percent, respectively, of the load at LW-8220 (fig. 37). If other metals have different percentages, particularly at W-GE, then we might assume that there was some loading along the east braid, most likely from the
Imperious tailings. The same reasoning might be used at other sites, but this one is of particular interest for metal loading. For $\mathrm{SO}_{4}$ loading, the percentages are comparable: 52 percent for $\mathrm{W}-\mathrm{G}$ and 48 percent for $\mathrm{W}$ G-East (fig. 38). For Mn (fig. 39) and Zn (fig. 40) loads, however, the percentages are reversed, and W-G only accounts for 46 and 43 percent, respectively. Thus, there is some indication of loading in this small reach of stream because of the highly acidic inflows of W-F and LW-8340.

\section{SUMMARY-IMPLICATIONS FOR REMEDIATION}

Metal loading in the Willow Creek watershed was quantified by establishing the hydrologic framework for chemical synoptic sampling in a series of tracer injections. Mass-loading results have shown that there is not a substantial contribution from any of the possible sources in lower Willow Creek, although the loads from sources upstream of Creede, Colorado, mostly are transported to the Rio Grande River through the lower Willow Creek area. Load profiles from West Willow Creek indicate that the greatest loading of metals in the Willow Creek watershed comes from the Nelson Tunnel inflow, accounted for at sampling site WW-F. This is a particularly substantial loading for $\mathrm{Zn}$ and other metals. Other stream segments, just downstream from WW-F, contribute substantial amounts of metals, including additional $\mathrm{Zn}$ load. It is possible that these secondary loadings result from water that leaks into the waste-rock pile and enters the stream farther down the drainage. Any remediation plan should account for those secondary sources, whether they are part of the Nelson Tunnel loading or not. East Willow Creek is not a significant source of metal loads. This could be a result of previous,

Table 7. Change in load through study reach of lower Willow Creek, Colorado, August 2000

[All values reported in kilograms per day; <, less than]

\begin{tabular}{|c|c|c|c|c|c|c|c|c|}
\hline Calculation & $\begin{array}{c}\text { Alu- } \\
\text { minum }\end{array}$ & $\begin{array}{l}\text { Cad- } \\
\text { mium }\end{array}$ & Copper & Iron & $\begin{array}{c}\text { Man- } \\
\text { ganese }\end{array}$ & $\begin{array}{c}\text { Stron- } \\
\text { tium }\end{array}$ & Zinc & Sulfate \\
\hline Sum of load from two braids of Willow Creek & 7.3 & 0.6 & 0.8 & 2.7 & 17.0 & 6.0 & 93.7 & 2,062 \\
\hline Net gain through study reach (including Wasson diversion) & 1.1 & 0 & .4 & -.9 & -1.1 & .8 & -14.2 & 436 \\
\hline Net gain in the Rio Grande River & 13.4 & .5 & -13.9 & 19.0 & 21.3 & 4.7 & 89.7 & 2,088 \\
\hline Unsampled inflow to Rio Grande River & 6.1 & $<1$ & $<1$ & 16.3 & 4.3 & $<1$ & $<1$ & 22 \\
\hline
\end{tabular}




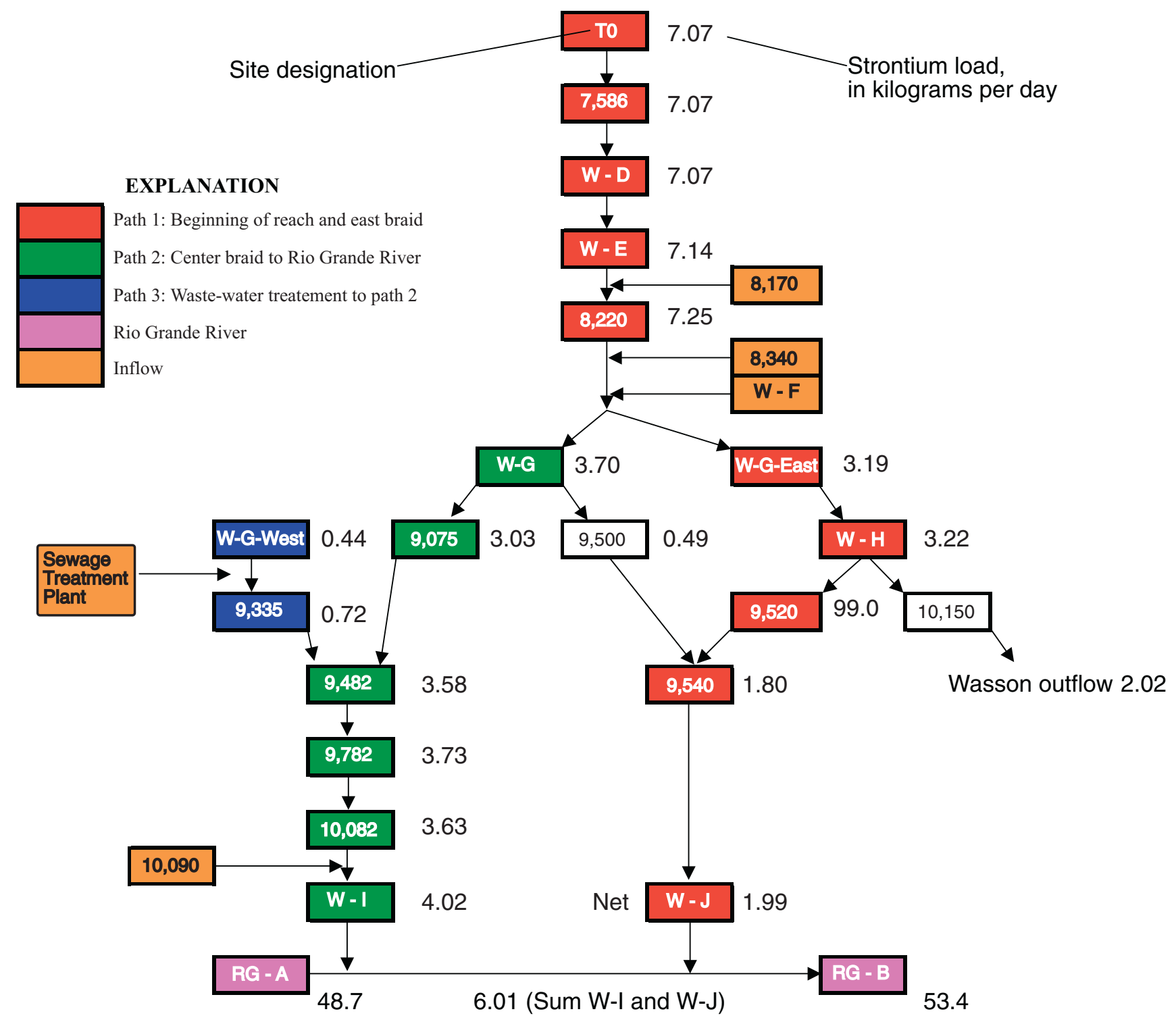

Figure 37. Total strontium load at synoptic sampling sites, lower Willow Creek, Colorado, August 2000. 


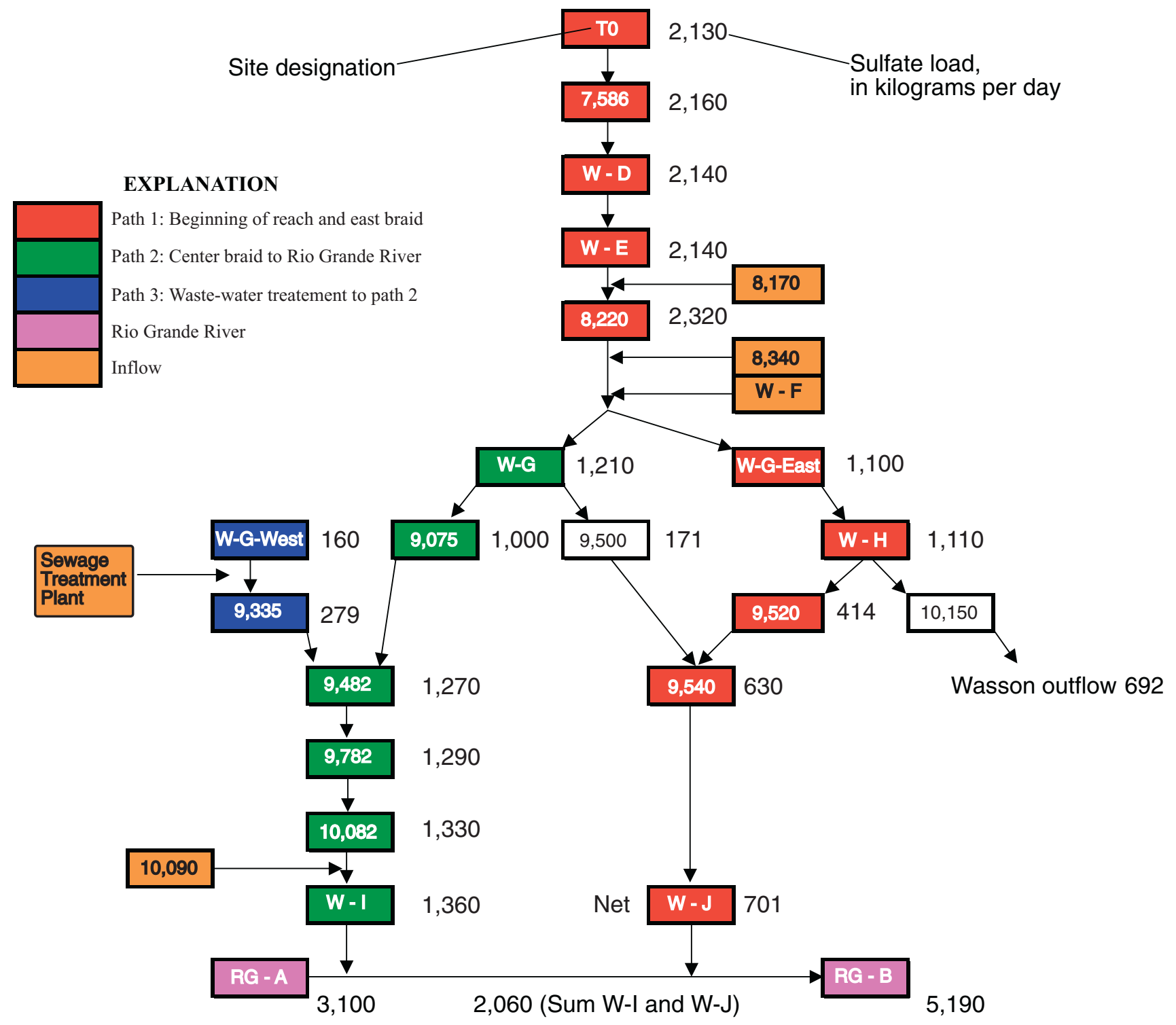

Figure 38. Total sulfate load at synoptic sampling sites, lower Willow Creek, Colorado, August 2000. 


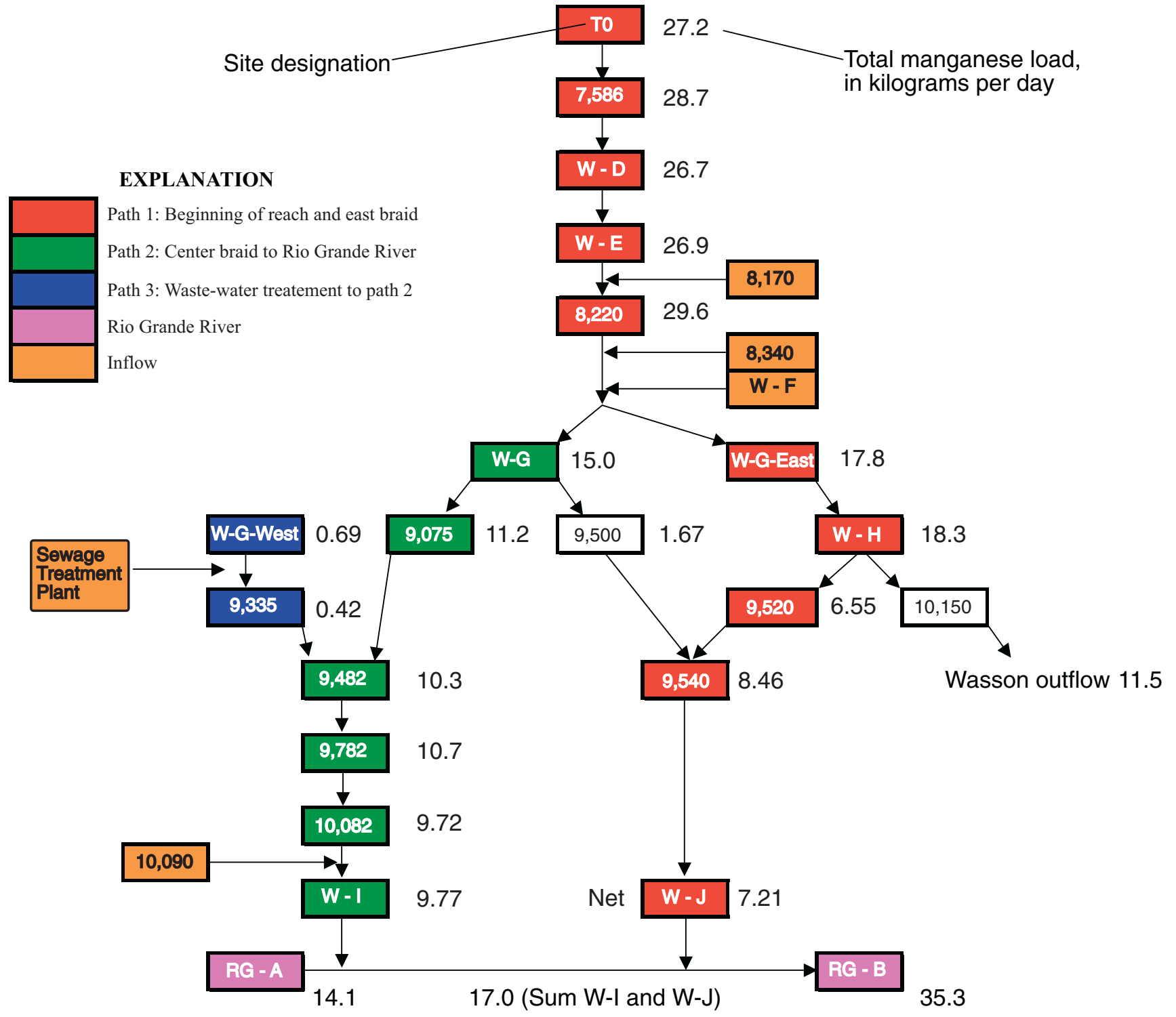

Figure 39. Total manganese load at synoptic sampling sites, lower Willow Creek, Colorado, August 2000. 


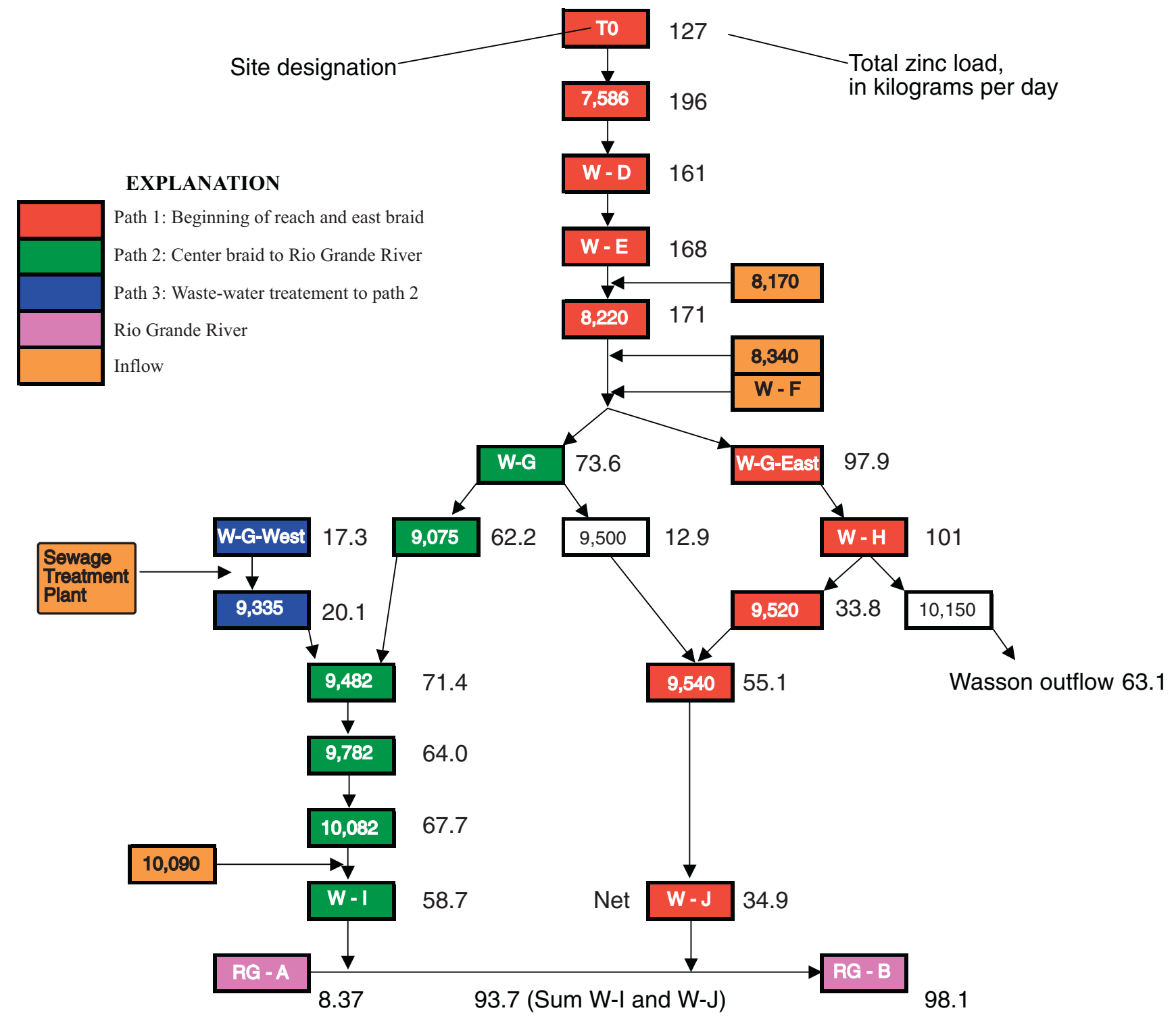

Figure 40. Total zinc load at synoptic sampling sites, lower Willow Creek, Colorado, August 2000. 
remediation efforts in that drainage. In summary, these tracer-injection studies have given a watershed picture of the metal-loading in streams near Creede, Colorado. Metal loading is dominated by the inflow from the Nelson Tunnel, however, there also were dispersed, subsurface inflows that add substantial loads.

\section{REFERENCES CITED}

Bencala, K.E., and McKnight, D.M., 1987, Identifying instream variability: Sampling iron in an acidic stream, in, Averett, R.C. and McKnight, D.M., eds., Chemical Quality of Water and the Hydrologic Cycle: Chelsea, Mich., Lewis Publishers, Inc., p. 255-269.

Bencala, K.E., McKnight, D.M., and Zellweger, G.W., 1990, Characterization of transport in an acidic and metal-rich mountain stream based on a lithium tracer injection and simulations of transient storage: Water Resources Research, v. 26, p. 989-1000.

Besser, J.M., Brumbaugh, W.G., May, T.W., Church, S.E., and Kimball, B.A., 2001, Bioavailability of metals in stream food webs and hazards to brook trout (Salvelinus fontinalis) in the upper Animas River watershed, Colorado: Archive of Environmental Contamination and Toxicology, v. 40, p. 48-59.

Besser, J.M., and Leib, K.J., 1999, Modeling frequency of occurrence of toxic concentrations of zinc and copper in the upper Animas River, in Morganwalp, D.W., and Buxton, H.T., eds., U.S. Geological Survey Toxic Substances Hydrology Program-Proceedings of the Technical Meeting, Charleston, S.C., March 8-12, 1999, v. 1, Contamination from Hardrock Mining: U.S. Geological Survey Water-Resources Investigations Report 99-4018A, p. 75-81.

Broshears, R.E., Bencala, K.E., Kimball, B.A., and McKnight, D.M., 1993, Tracer-dilution experiments and solute-transport simulations for a mountain stream, Saint Kevin Gulch, Colorado: U.S. Geological Survey Water-Resources Investigations Report 92-4081, 18 p.

Cleasby, T.E., Nimick, D.A., and Kimball, B.A., 2000, Quantification of metal loads by tracer-injection and synoptic sampling methods in Cataract Creek, Jefferson County, Montana, August 1997: U.S. Geological Survey Water-Resources Investigations Report 004237, $39 \mathrm{p}$.

Clements, W.H., 1994, Benthic invertebrate community responses to heavy metals in the upper Arkansas River basin, Colorado: Journal of the North American Benthological Society, v. 13, no. 1, p. 30-44.
Daultrey, S., 1976, Principal components analysis: Concepts and techniques in modern geography No. 8: London, Institute of British Geographers, $50 \mathrm{p}$.

Grundy, W.D., and Miesch, A.T., 1985, Brief descriptions of STATPAC and related statistical programs for the IBM personal computer: U.S. Geological Survey Open-File Report 87-411-A, 34 p.

Jarrett, R.D., 1992, Hydraulics of mountain rivers, in Yen, B.C., ed., Channel Flow Resistance Centennial of Manning's Formula: International Conference of the Centennial of Manning's and Kuichling's Rational Formula: Littleton, Colo., Water Resources Publications, p. 287-298.

Joreskog, K.G., Klovan, J.E., and Reyment, R.A., 1976, Geological factor analysis: New York, Elsevier Scientific Publishing Co., 178 p.

Kilpatrick, F.A., and Cobb, E.D., 1985, Measurement of discharge using tracers: Techniques of Water-Resources Investigations of the U.S. Geological Survey, Book 3, Chap. A16.

Kimball, B.A., 1997, Use of tracer injections and synoptic sampling to measure metal loading from acid mine drainage: U.S. Geological Survey Fact Sheet FS-24596.

Kimball, B.A., Bencala, K.E., and Broshears, R.E., 1994, Geochemical processes in the context of hydrologic transport: Reactions of metals in St. Kevin Gulch, Colorado, in, Dutton, A., ed., Toxic Substances in the Hydrologic Sciences: Minneapolis, Minn., American Institute of Hydrology, p. 80-94.

Kimball, B.A., Callender, E., and Axtmann, E.V., 1995, Effects of colloids on metal transport in a river receiving acid mine drainage, Upper Arkansas River, Colorado, U.S.A.: Applied Geochemistry, v. 10, p. 285306.

Kimball, B.A., McKnight, D.M., Wetherbee, G.A., Harnish, R.A., 1992, Mechanisms of iron photoreduction in a metal-rich, acidic stream, St. Kevin Gulch, Colorado, U.S.A.: Chemical Geology, v. 96, p. 227-239.

Kimball, B.A., Nimick, D.A., Gerner, L.J., and Runkel, R.L., 1999a, Quantification of metal loading in Fisher Creek by tracer injection and synoptic sampling, Park County, Montana, August 1997: U.S. Geological Survey WaterResources Investigations Report 99-4119, 40 p.

Kimball, B.A., Runkel, R.L., and Gerner, L.J., 1999b, Quantification of metal loading in French Gulch, Summit County, Colorado, using a tracer-injection study: U.S. Geological Survey Water-Resources Investigations Report 98-4078, 38 p.

Kimball, B.A., Runkel, R.L., and Gerner, L.J., 2001, Quantification of mine-drainage inflows to Little Cottonwood Creek, Utah, using a tracer-injection and synoptic sampling study: Environmental Geology, v. 10, p. 1390-1404. 
Kimball, B.A., Runkel, R.L., Walton-Day, K., and Bencala, K.E., 2002, Assessment of metal loads in watersheds affected by acid mine drainage by using tracer injection and synoptic sampling: Cement Creek, Colorado, USA: Applied Geochemistry, v. 17, p. 1183-1207.

Lichte, F.E., Golightly, D.W., and Lamothe, P.J., 1987, Inductively coupled plasma-atomic emission spectrometry: U.S. Geological Survey Bulletin 1770, 10 p.

McKinnon, T.E., 2002, Sources and seasonal variability of metal and arsenic concentrations in the surface water of the Clark Fork River Basin, Montana: University of Montana Master's thesis.

Rantz, S.E., and others, 1982, Measurement and computation of streamflow: Volume 1. Measurement of stage and discharge: U.S. Geological Survey WaterSupply Paper 2175, $631 \mathrm{p}$.

Runkel, R.L., Kimball, B.A., McKnight, D.M., and Bencala, K.E., 1999, Reactive solute transport in streams: A surface complexation approach for trace metal sorption: Water Resources Research, v. 35, no. 12, 3829-3840.

Steven, T.A., and Ratté, J.C., 1965, Geology and structural control of ore deposition in the Creede District, San Juan Mountains, Colorado: U.S. Geological Survey Professional Paper 487, 90 p.

Taylor, J.R., 1997, An introduction to error analysis: The study of uncertainties in physical measurements, 2nd edition: Sausalito, California, University Science Books, $327 \mathrm{p}$.

Ward, J.R., and Harr, C.A., 1990, Methods for collection and processing of surface-water and bed-material samples for physical and chemical analyses: U.S. Geological Survey Open-File Report 89-140, 71 p.

Zellweger, G.W., 1994, Testing and comparison of four ionic tracers to measure stream flow loss by multiple tracer injection: Hydrological Processes, v. 8, p. 155-165.

Zellweger, G.W., Avanzino, R.J., and Bencala, K.E., 1989, Comparison of tracer-dilution and current-meter discharge measurements in a small gravel-bed stream, Little Lost Man Creek, California: U.S. Geological Survey Water-Resources Investigations Report 894150, $20 \mathrm{p}$. 


\section{APPENDIX-RESULTS OF CHEMICAL ANALYSES FOR SYNOPTIC SAMPLES COLLECTED NEAR CREEDE, COLORADO}

The appendix consists of two tables available as PDF files. These files are linked from their titles below.

Table A-1. Physical properties of synoptic samples collected near Creede, Colorado, August and September 2000

Table A-2. Concentration of chemical constituents in synoptic samples collected near Creede, Colorado, August and September 2000 
